\title{
CARTON CLAMP TEST METHODOLOGIES AND THE EFFECT ON LOAD CONTAINMENT AND RETENTION
}

\author{
A Thesis \\ presented to \\ The Faculty of California Polytechnic State University, \\ San Luis Obispo
}

\author{
In Partial Fulfillment \\ of the Requirements for the Degree \\ Master of Science in Business and Technology
}

by

Tyler Don Blumer

December 2013 
(C)2013

Tyler Don Blumer

ALL RIGHTS RESERVED 


\section{COMMITTEE MEMBERSHIP}

TITLE:

Carton Clamp Test Methodologies and the Effects on Load Containment and Retention
AUTHOR:
Tyler Don Blumer

DATE SUBMITTED: December 2013

COMMITTEE CHAIR: Dr. Jay Singh, Packaging Program Director Orfalea College of Business: Industrial Technology

COMMITTEE MEMBER: Dr. Koushik Saha, Assistant Professor Orfalea College of Business: Industrial Technology

COMMITTEE MEMBER: Dr. Soma Roy, Assistant Professor College of Science and Math: Statistics 


\section{ABSTRACT \\ Carton Clamp Test Methodologies and the Effects on \\ Load Containment and Retention}

Tyler Don Blumer

A carton clamp is an alternative device for moving packages and material. Instead of using iron tines like that of a conventional forklift, a carton clamp uses two large aluminum platens to slightly compress and secure the load for handling. This is advantageous as it allows operators to move layers of a unitized load individually, and eliminates the need for a pallet when handling full unitized loads. When using a carton clamp attachment, it is often difficult for operators to accurately gauge the amount of force being applied to the load. The required clamping force changes depending on the size, shape, and weight of the load. This creates the potential for under-clamping (slippage) and over-clamping (compressive damage). Seeing a market need for a reliable means of testing, two organizations set out to develop a testing protocol.

A rift formed between schools of thought regarding the correct testing procedure. ISTA provides a sterile, calculated, and stationary simulation of carton clamp handling in its ISTA 6-SAMS test protocol. ASTM offers a more holistic, dynamic, observational approach in its mobile ASTM 6055 standard protocol. One school of thought is suggested to imply that a package should be developed to be handled by the carton clamp (ASTM). The other school of thought is that the carton clamp attachment should be properly adjusted to the package specimen (ISTA). 
Previous studies have been performed citing the ISTA standard and using a specialized carton clamping device vibration device that is calibrated for laboratory research. Arguably, this method, though repeatable in nature, does not accurately simulate carton clamp handling found in industry. Likewise, the equipment investment is cost prohibitive for those in industry wishing to duplicate such a study. ASTM uses a carton clamp truck as used in industry, but does not specify any specific parameters making repeatability between laboratories and practitioners ambiguous.

This study examined whether or not a common ground can be reached; implementing a carton clamp lift truck as found in industry allowing for mobile (hazard course) testing. A modified version of ISTA 3B will be paired off against ASTM 6055 for evaluating both column and cross stack pallet patterns with a variety of treatments. This study attempted to determine if carton clamps as found in industry are capable and repeatable enough to provide consistent data. Similarly, this study examined the test methodologies effect on load containment via stretch film force, load retention via unitized load slippage, and the effects of ride height and driver interaction. The study sought to understand if these effects are uniform across the unitized load, or if particular layers of the load more affected than others. 


\section{ACKNOWLEDGMENTS}

I would like to thank the following people for their help with my master's thesis.

- Dr. Jay Singh - Cal Poly

- Dr. Koushik Saha - Cal Poly

- Dr. Soma Roy - Cal Poly

- $\quad$ Raymond Kisch -- Cal Poly

- John Franzia -- Bronco Wineries

- $\quad$ Luke Venechuk - Highlight Industries 


\section{TABLE OF CONTENTS}

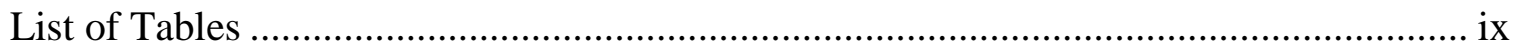

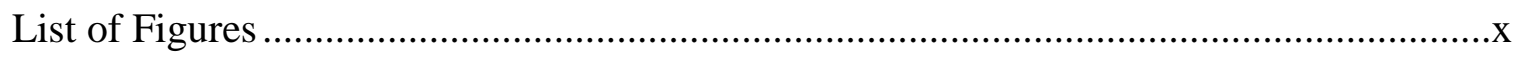

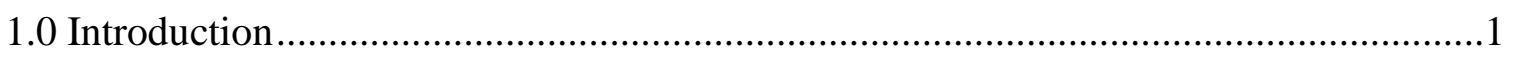

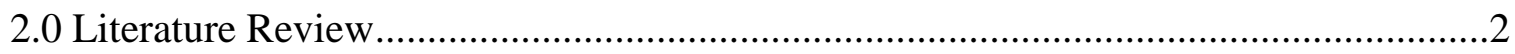

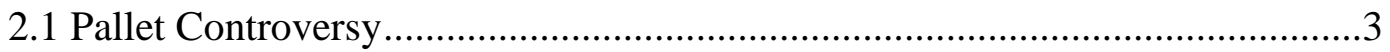

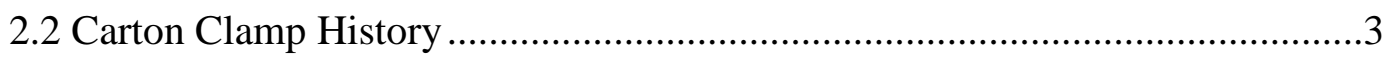

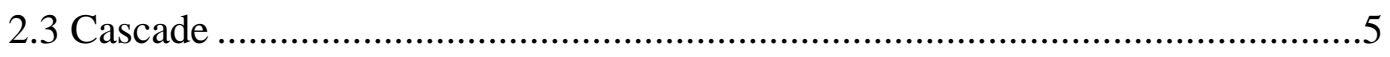

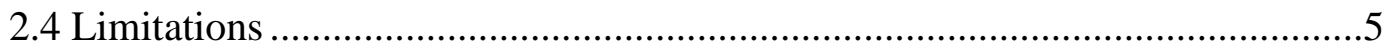

2.5 Forces at Work .................................................................................. 7

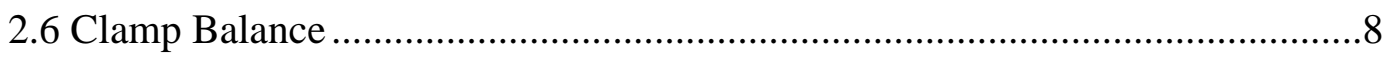

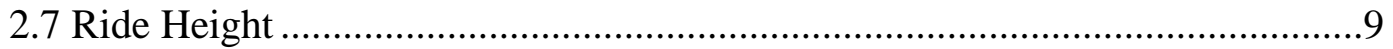

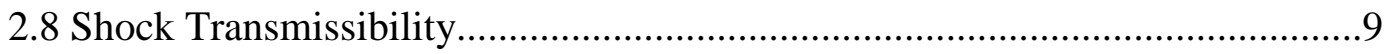

2.9 Stretch Wrapping of Unitized Loads .....................................................10

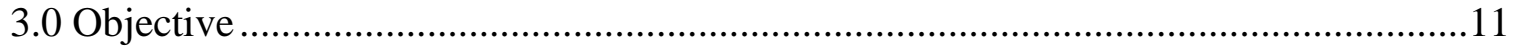

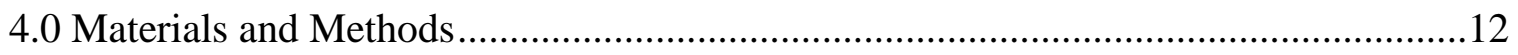

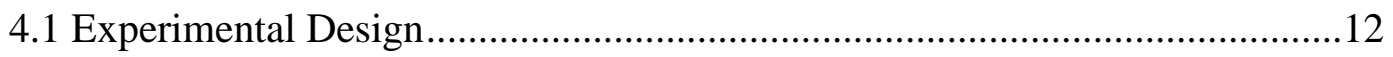

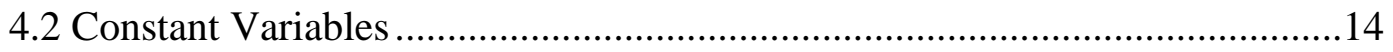

4.3 Constructing the Unitized Loads ........................................................ 14

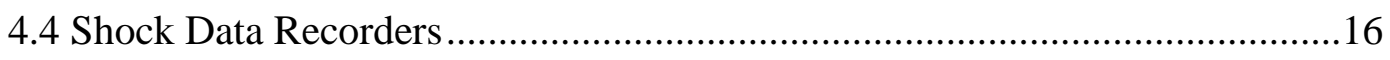

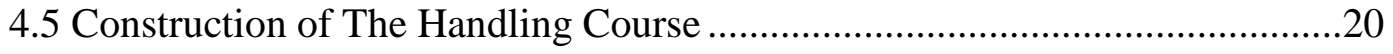

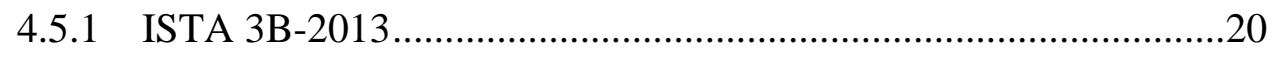

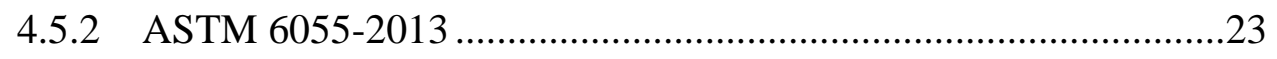

4.6 Portable Film Force System ...................................................................26

4.6.1 Portable Film Force System Set up.........................................26

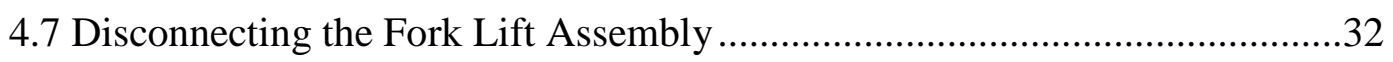

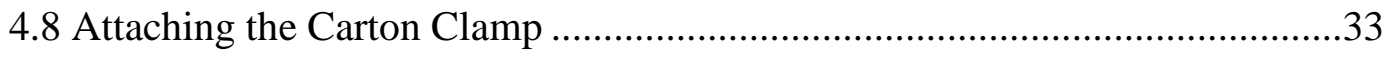

4.8.1 Adjusting Maximum Clamp Pressure ......................................35

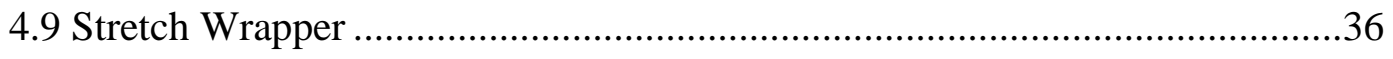

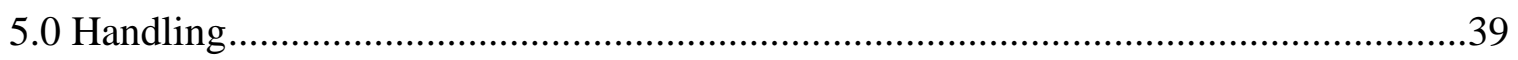




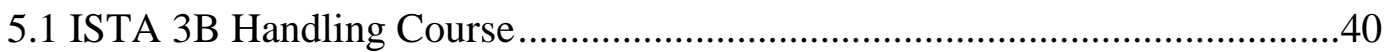

5.2 ASTM D6055-2013 Handling Course .............................................................45

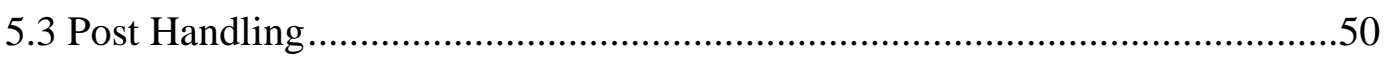

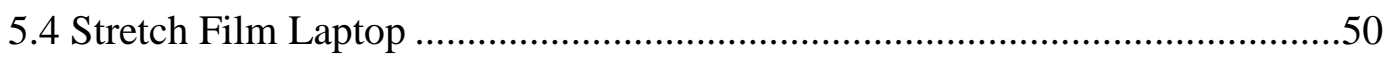

6.0 Results and Discussion ......................................................................................52

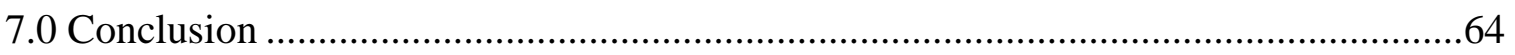

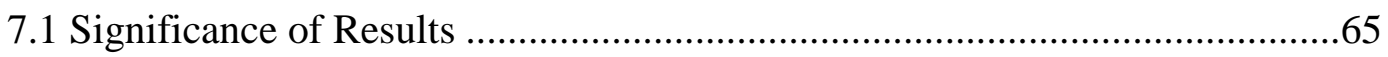

7.2 Suggested Future Research .....................................................................65

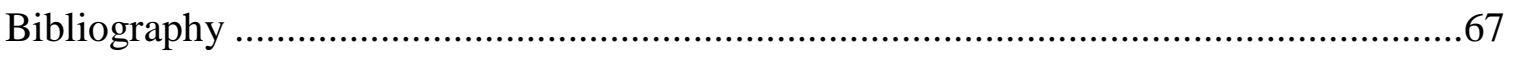

Appendices

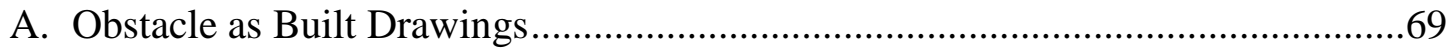

B. Statistical Output Data for Scenarios .....................................................................

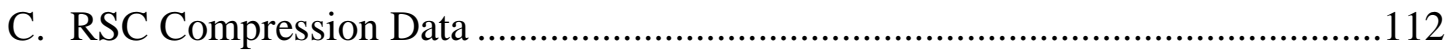

D. Corrugated Edge Crush Data ..........................................................................114

E. Coefficient of Friction Data Between Materials .................................................115 


\section{LIST OF TABLES}

Table 1: Randomized Column Stack Test Schedule...........................................13

Table 2: Randomized Cross Stack Test Schedule................................................13

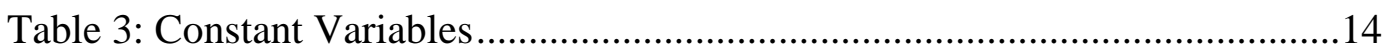

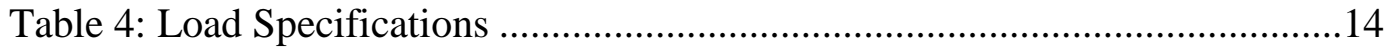

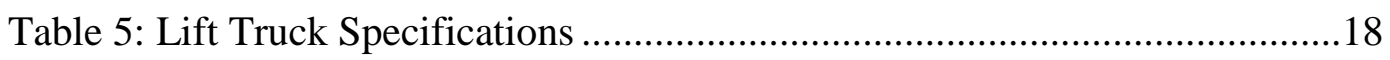

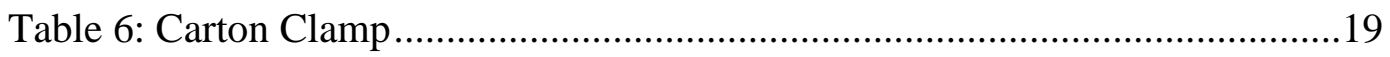

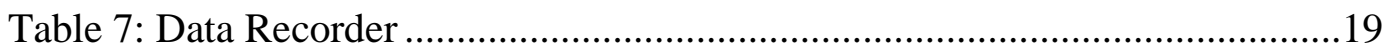

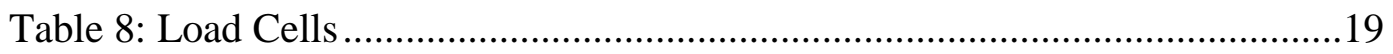

Table 9: Carton Clamp Force Indicator ........................................................19

Table 10: Mean shock (SE) values for column stack pattern by factor. ................54

Table 11: Mean shock (SE) values for cross stack pattern by factor....................55

Table 12: Quantity of shock events for column stack patterns by factor...............56

Table 13: Quantity of shock events for cross stack pattern by factor. ..................57

Table 14: Slippage for column stack pattern by factor...................................58

Table 15: Slippage for cross stack pattern by factor .....................................59

Table 16: Stretch film containment force on column stack pattern by factor........60

Table 17: Stretch film containment force on cross stack pattern by factor. ..........62 


\section{LIST OF FIGURES}

Figure 1 L.G. Ehmann's Inventions ............................................................................ 4

Figure 2: Stack Height with Conventional Pallet …………............................................ 6

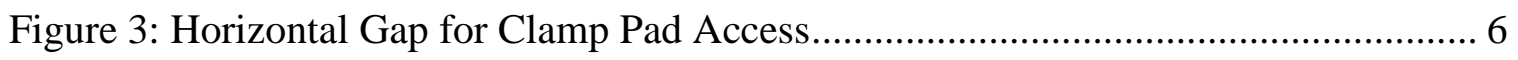

Figure 4: Cross Stacked Unitized Load ................................................................. 15

Figure 5: Column Stacked Unitized Load ............................................................ 15

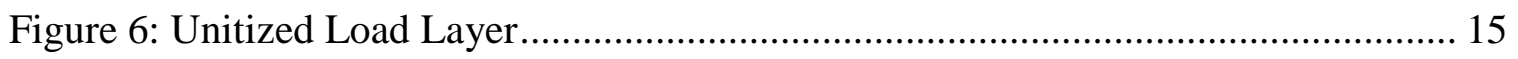

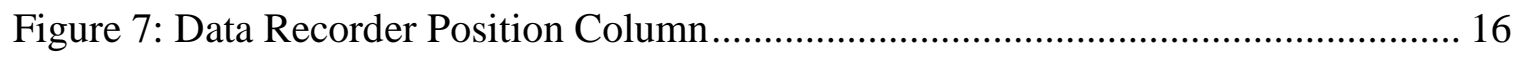

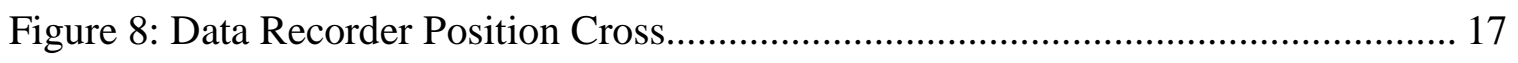

Figure 9: Extruded Aluminum Fixture in RSC ...................................................... 17

Figure 10: Data Recorder Position Truck ……………............................................ 18

Figure 11: Modeling and Construction of Plate Obstacles ............................................. 22

Figure 12: Plate Obstacle Course ISTA 3B-2013 ………........................................... 22

Figure 13: Wooden Obstacle Isometric ................................................................. 24

Figure 14: Wooden Obstacle Profile...................................................................... 24

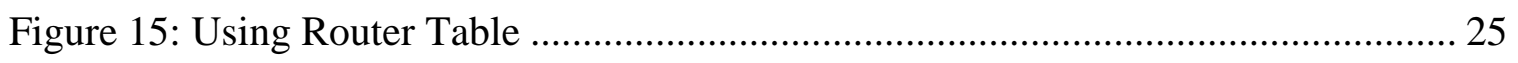

Figure 16: Primary Load Cell ........................................................................... 26

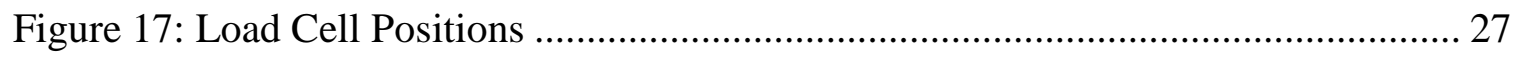

Figure 18: Wireless Launch Utility...................................................................... 28

Figure 19: Verifying Communication to Load Cells ..................................................... 28

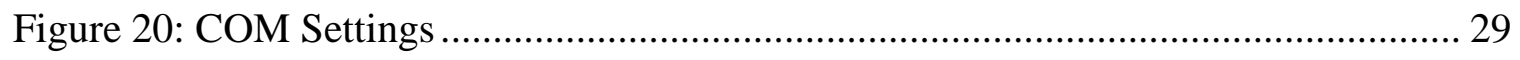

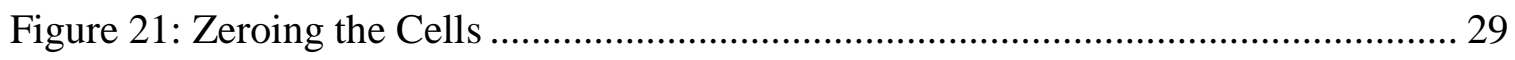

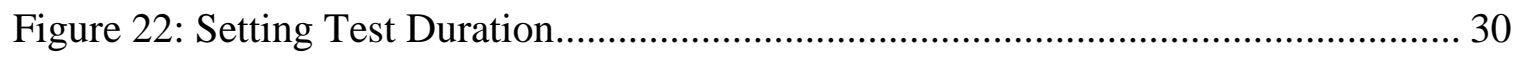

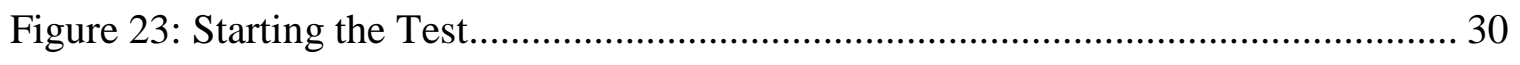

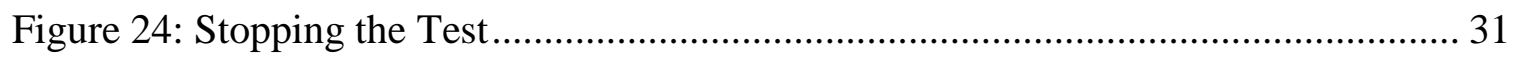

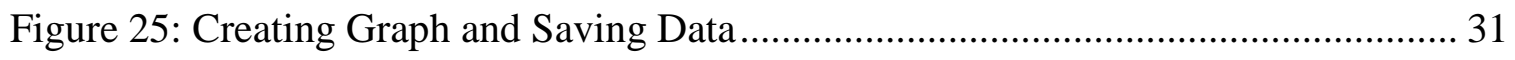

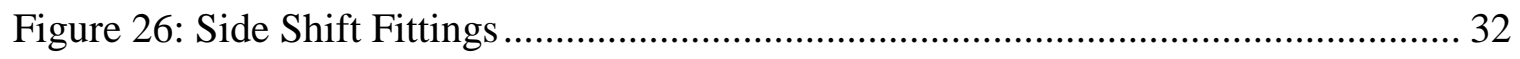

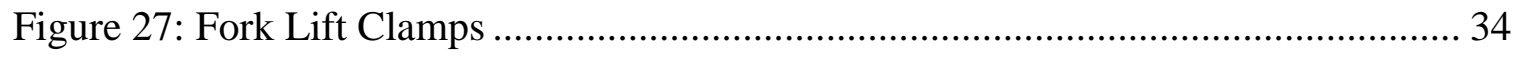

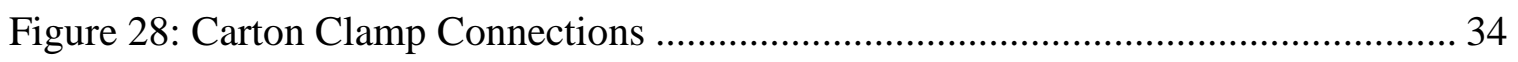

Figure 29: Adjusting Maximum Clamp Force Pressure ……………………………..... 35

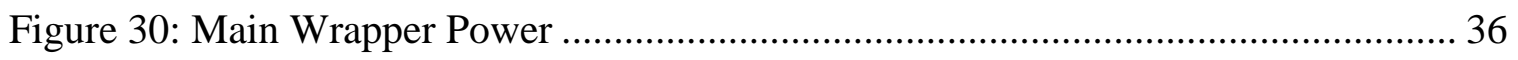

Figure 31: Navigation Screen ……………........................................................... 37

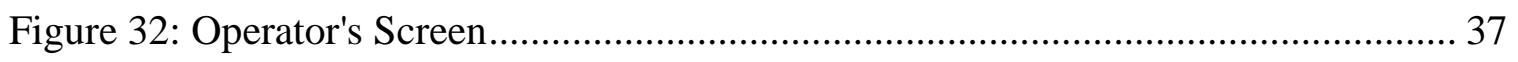

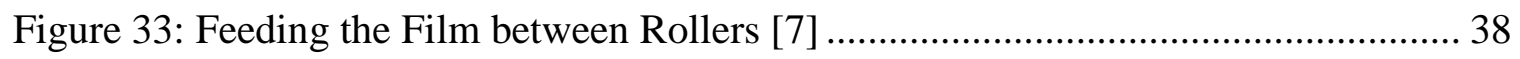

Figure 34: Load Positioning..................................................................................... 39

Figure 35: ISTA 3B-2013 Course with Plate Obstacles Identified................................... 40

Figure 36: ISTA 3B-2013 Start Position ………………........................................ 41

Figure 37: Setting the Correct Ride Height ................................................................. 42

Figure 38: Measuring Load Position between Clamp Pads .............................................. 42 


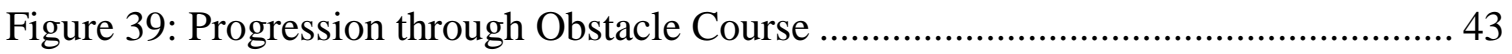

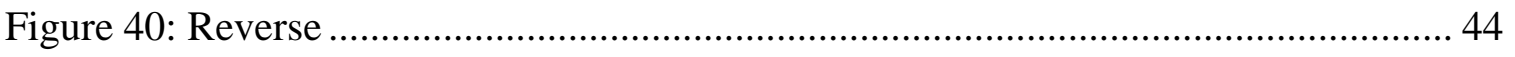

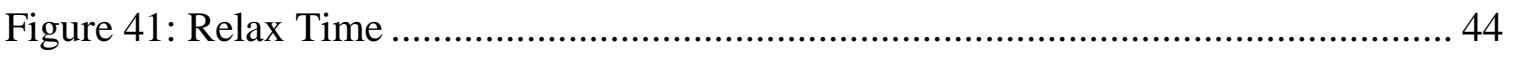

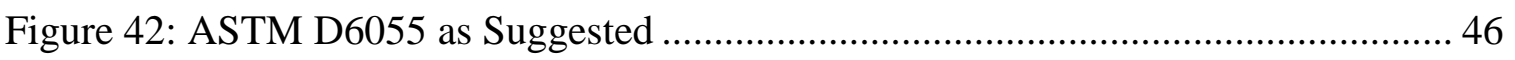

Figure 43: Handling Course as Performed .............................................................. 46

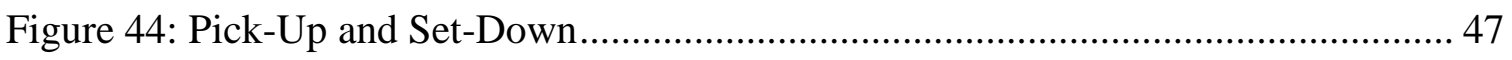

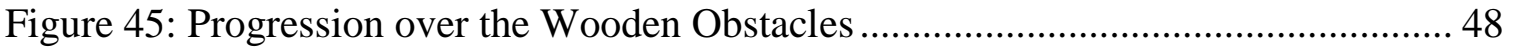

Figure 46: Left Turn after Wooden Obstacles .......................................................... 49

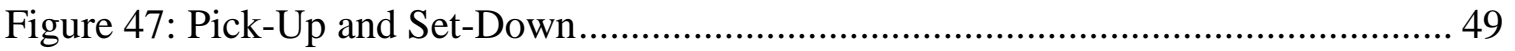

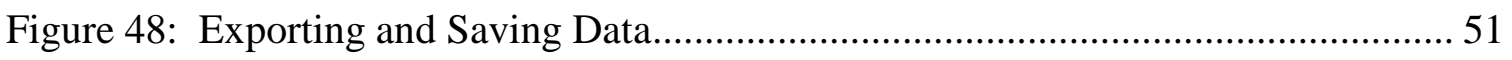

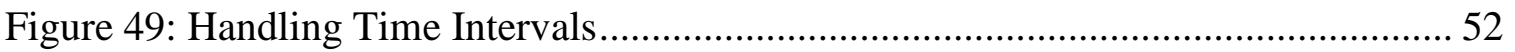

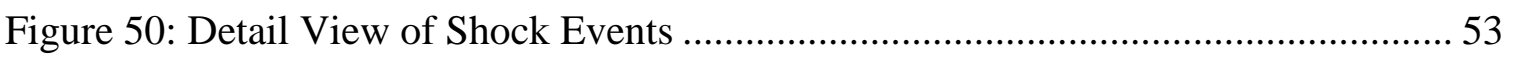




\subsection{Introduction}

Carton clamps are increasingly popular technology of material handling. Carton clamps are gaining popularity in the food, wine, processed paper, consumer electronic, and home appliance industries. The use of carton clamps is a relatively untapped resource as they can be implemented in a multitude of industries providing the packaged loads being handled meet certain criteria. Cascade corp. the industry leader in carton clamp attachments, states in a 2011 implementation article that a carton clamp can be applied successfully if the unitized loads being handled are uniform in nature and have a minimum of voids in the pallet pattern. Likewise, the cartons must be a minimum of seven inches tall and provide enough structural rigidity to protect the contents from the effects of horizontal compression. [16] Carton clamp technology is primarily intended for handling, stacking, and picking loads with in a warehouse environment. Carton clamp attachments are often paired with slip sheet technology or conventional wood pallets for shipping and distribution. 


\subsection{Literature Review}

\subsection{Pallet Controversy}

Wooden pallets have proven themselves a resilient technology as they have out lasted and out competed alternative means of material handling for the past century despite frequent criticisms. Wooden pallet usage is criticized as they present a number of economic, environmental, and ecological problems. The pallet industry processes 4.5 billion board feet of hardwood and 1.8 billion board feet of softwood lumber, representing between 400 and 500 million pallets sold each year. [13] There are approximately 1.2 billion hardwood pallets currently in circulation within the United States representing $83 \%$ of the domestic pallet and material handling industry. This pool of white wood pallets is owned by more than 5,000 independent companies. It is estimated that $40 \%$ of all the hardwood logged in the United States is used for manufacturing wooden pallets. [14] This percentage is highly debated as the National Wooden Pallet and Container Association (NWPCA) argues that much of the wood used for pallet making is a byproduct of the housing and furniture industries.

Food-borne illnesses such as salmonella and E. coli cost the United States upwards of 150 billion dollars in health-care and monetary loses each year. Wooden pallets have been hypothesized as a possible vector for transmitting these pathogens to food products. The USDA supports this theory stating that wooden pallets are often difficult to clean based on their porous nature. [15] Independent studies conducted by the German Institute for Food Technology and a Nordic Company found that bacteria growth on wooden pallets was $15 \%$ lower than that of a plastic equivalent. This finding is theorized to be an 
effect of hard woods natural antimicrobial properties. [15] The NWPCA states that pathogen pallet contamination has never been linked to any food or drug recall in the United States and cites a 60 year track record of safety.

The wooden pallet has however facilitated the spread of the pests and insects between continents. The non-indigenous species of pest have the potential to gravely threaten the native environment as well as forest resources. Over the past 200 years, more than 400 unique species of insect have been introduced to the United States via cargo containers and wooden packaging supplies. [8] To stem the transfer of pest between continents, standards have been introduced to control the pallets that are traveling internationally. The International Standards for Phytosantitary Measure (ISPM) were introduced and adopted by the United States as well as 133 other countries with the specific purpose of stopping or significantly reducing the spread of wood pests globally. These standards mandate the use of treated wood in packaging supplies traveling between countries. The wood is to be treated via heat, methyl bromide gas fumigation, and or a vacuum-steam application.

\subsection{Carton Clamp History}

The rendition of the hydraulic carton clamp as it is known today was first filed June 11, 1948 by Leslie G. Ehmann on behalf of the Hyster Company of Portland, Oregon. The idea was patented October 16, 1951. In his claims, Ehmann states that a conventional lift truck cannot pick up a load which is resting flat on a warehouse floor. Ehmann explains that the hard wood pallet was a necessity to provide the gap needed for the conventional style tines to be utilized. Ehmann continues in his claims that forklifts cannot pick the top 
most of a stack of articles without a pallet in place to do so, "nor can they pick up the top part of a stack of articles such as boxes, cartons or barrels without the use of pallets or their equivalents in the stacks to allow space for entrance of the lift truck arms. Thus a very large number of pallets have heretofore been required for the handling of material by lift truck, which entails considerable expense.’[10] These excerpts from the patent claims highlight the primary benefits of this device.
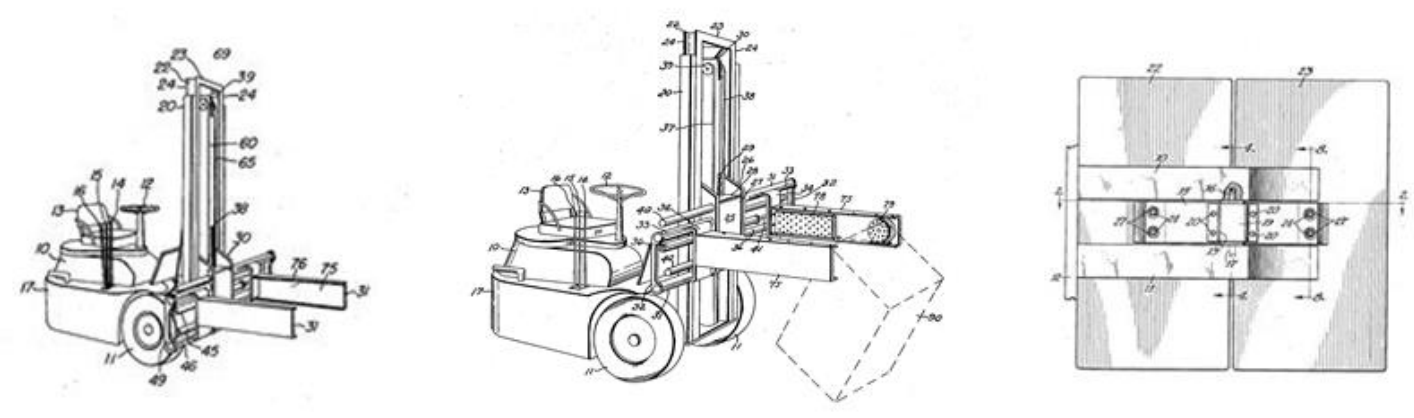

Figure 1: L.G. Ehmann's Inventions

Ehmann was a fervent innovator of industrial lift truck technology and in 1955 improved upon his previous design by adding rotatable clamping pads to lift attachment. The benefit of these indexing pads is that it allowed operators to turn over or upend large articles without manual handling. The device was intended for appliances, boxes and bundles of bulk goods. [11] Ehmann stresses in his claim that his device has the potential to eliminate the need for pallets as an operator can apply a direct hold to the subject being in need of handling. This patent also includes mention of adding rubber gripping pads to the clamp surface for increased friction and retention. Ehmann also pioneered the use of large flat platens for clamp attachments. A patent filed in 1950 and published in 1954 discusses the employment of movable contact plates mounted to the pressure arms. These 
contact plates that are opposed in mounting also feature provisions for the plates to articulate and retain loads with slight irregularities to shape.

\subsection{Cascade}

Cascade Corporation is the global industry leader for hydraulic clamp truck attachments. Founded in Portland Oregon in 1943 as a general machine shop, Cascade has since risen to the number one manufacturer of material handling attachments worldwide. [6] Their carton clamps are widely available and present in industry. It was for this reason that the study was based around the use of a cascade 2 Series carton clamp attachment.

\section{$2.4 \quad$ Limitations}

The carton clamp attachment is an excellent technology for stacking and picking articles in a warehouse storage environment. One of the flaws inherent in carton clamp handling is that the unitized load must eventually be put on a pallet or slip sheet for distribution. An article loaded by carton clamp into a truck or container for delivery must be unloaded by a carton clamp at the destination. Likewise, the vertical space saved by omission of the pallet under the article is traded for the horizontal space required by the clamp pads on either side of the article. In 1978 a case study was written documenting General Foods transition away from conventional pallet handling. The report states that by 1976 approximately half of all General foods unitized loads were handled by clamp trucks, but

the number of pallets required to ship the products had not changed. Pallets were required for distribution, because carton clamping requires a minimum of three to four inch horizontal gaps between loads to fit the clamp pads. The necessity to maintain clamp pad gaps during shipping and the cost of pre distribution stretch wrap halted progress. The 
General foods moved away from carton clamp handling and began to pursue a slip sheet alternative. [16]

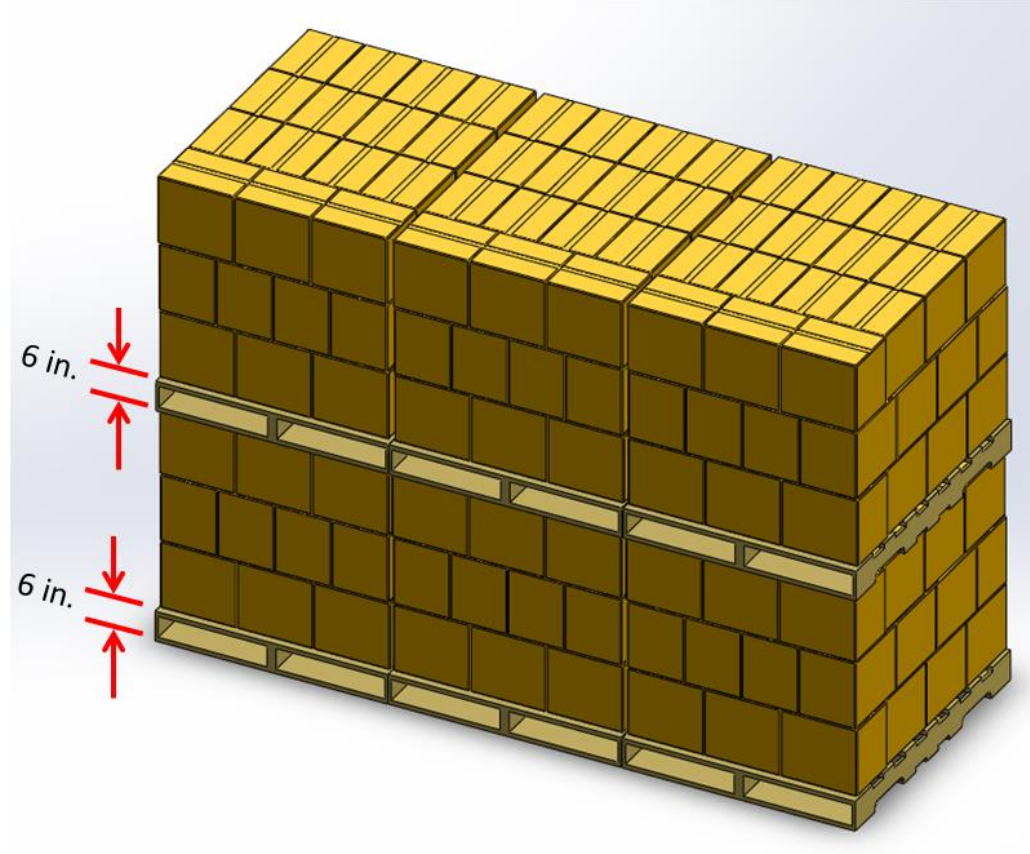

Figure 2: Stack Height with Conventional Pallet

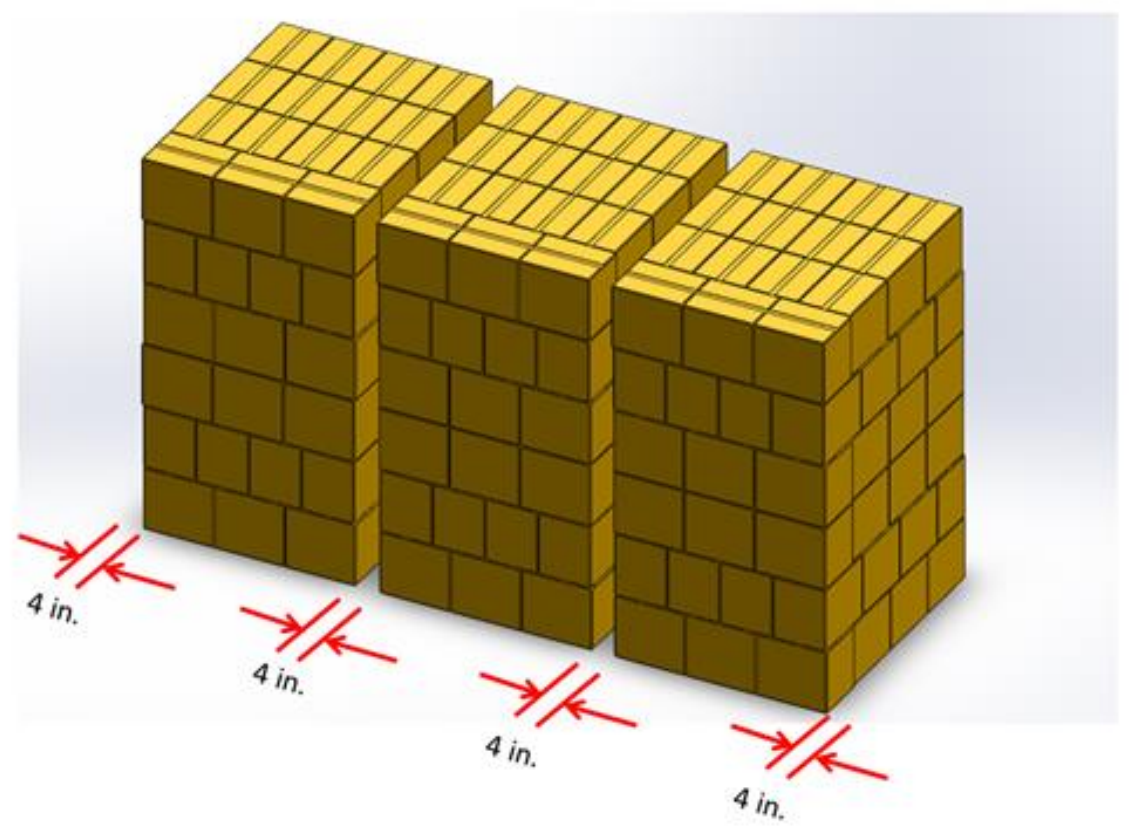

Figure 3: Horizontal Gap for Clamp Pad Access 


\subsection{Forces at Work}

Jamie Stewart of Clemson University cites in his 2005 paper Clamp Truck Simulation in the Laboratory Environment, four parameters directly affecting the clamp force required to handle a load. The four parameters were extracted from a list of seven parameters that originally applied to the handling of paper rolls. Stewart infers in his paper that these parameters can be applied to any object handled by clamp attachments. [17]

Contact pad friction was the deemed the most important factor influencing clamping force. The more friction that existed between the contact pads and the load being lifted, the less clamp, horizontal compression force was required to lift the given load. Closely after friction, weight of the object being handled was next most important factor. The more an object weighs, the more compression and corresponding frictional force is required to lift it. Elemental factors are cited as having the potential to reduce the coefficient of friction between the load and the clamp pads. Of these elemental factors water as snow and ice, or hydraulic oil have been noted to greatly affect clamp pad friction, necessitating an increase in clamp pressure to retain the load. Dynamic forces are then mentioned for the profound effect they have on load retention. Stewart and Batt speculate that dynamic weight of a clamped load is approximately double that of a static load. Implying that any time the load must be handled and moved, roughly twice the clamp force required to lift the load should be applied for secure handling. [17] 


\subsection{Clamp Balance}

The balance of a clamp attachment is determined by how evenly it applies compressive force to the article it handles. The larger a clamp pad is, the more potential that pad has for an imbalance in clamping force. [18] An imbalanced carton clamp applies more clamp force to a specific area in a unitized load, such as the top, bottom, front or back of the load. Clamp imbalance creates the possibility for product damage as a result of over compressing an area of the load and poor overall load retention which leads to dropped cartons via slippage. This geometric relationship of the two clamp pads can be expressed as toe and chamber, toe representing the horizontal front-to-back orientation and chamber the vertical top-to-bottom orientation. Pivoting, or articulating clamps have been used successfully to remedy minor problems with clamp balance as their hinged design allows for slight give in the previously rigid pad structure.

Currently, there is no commercially available way to accurately measure and determine the balance of a carton clamp attachment. The most common means of measuring clamp force is measured using a single point of contact on each pad. These electronic load cells or hydraulic gauges do not take into account the angle and possible miss alignment of pads. A 2012 patent filed by inventors Andrew Suhy and Chad Truckor on behalf of assignee Total Fleet Solutions, proposes a machine that can not only measures the force of a clamp attachment, but also determine its balance. The test device utilizes multiple load cells situated symmetrically about a rigid rectangular fixture. The load cells feed an electrical signal back to a centralized computer which displays the force values at multiple locations on the pads in real time. The suggested computer can process the multiple force values and determine the overall clamp balance. [18] 


\subsection{Ride Height}

According to the requirements and recommended practices specified in Load handling chapter of the OSHA Safety and Health guide, the safe ride height for a lift truck to transport its subject is between 4 and 6 inches off the ground. [19] Preliminary test runs were conducted to determine the lowest possible ride height for a clamp attachment without the risk of impacting the ground or obstacles. The safe ride height was determined to be six inches off the ground. To test the reasonable extremes of this ride height differential, six and twelve inches were chosen for the test ride heights. Twelve inches was considered to be the maximum acceptable ride height before it became unconventional in industry or similarly unsafe to transport the load.

\subsection{Shock Transmissibility:}

When a lift truck collides with a length of debris or an uneven surface in a warehouse environment, a shock pulse or event will occur. The event, which occurs almost instantaneously, is expressed by its intensity of acceleration (G's) and its duration in

milliseconds. As carton clamps are used in relatively small numbers compared to that of the conventional forklift, very little is known about how the products carried by clamp experience these shock events. The effect that a carton clamp has on the load being carried is either amplification meaning that the shock event is magnified or intensified in terms of acceleration, or attenuation in which the shock is dampened or reduced as some result of the mechanical linkages or physics of the device.

Previous studies have been conducting examining shock transmissibility with a conventional fork lift truck, but not for a carton clamp attachment. Previous studies have 
found that Transmitted shock intensity increases proportionally to the intensity or velocity of the input. Cartons and shippers located towards the center of a unit load experience attenuated shock regardless of the direction of the shock input. Finally that interlock (cross-stack) patterns are more susceptible to the transmission of shock throughout the unitized load. [12]

\subsection{Stretch Wrapping of Unitized loads}

Stretch wrapping a unitized load with linear low density polyethylene (LLDPE) has the advantage of increasing load containment. Containment is important in that it keeps the load unitized as one object during distribution and handling. Column stacked unitized loads benefit greatly from the addition of stretch film as the individual columns tend to separate during distribution.[7] Once separated the individual columns have a high risk falling outward, this is known as flowering. The tendency for a column stacked unitized load to flower is based primarily on the height of the load and foot print of the individual boxes. That is to say that a case or carton with a larger foot print and lower center of gravity is less likely to flower than packages with a smaller foot print and higher center of gravity. 


\subsection{Objective}

The objective of this study was to explore the use of a carton clamp lift truck for laboratory testing. Cases of water filled glass wine bottles were constructed into cross and column stacked patterned loads. The loads which consisted of 45 cases of wine, 12 bottles per case, were subjected to a modified version of the ISTA 3B handling course and the ASTM D 6055 handling course. The study intends to identify how differences in the two test methodologies affect the two differently stacked loads being carried. Load retention measured as slippage, shock intensity and duration, and load containment measured as measured by the film force will be observed. 


\subsection{Materials and Methods}

\subsection{Experimental Design}

To examine the differences between stacking pattern, obstacle course, and ride height, two unitized loads were constructed. The first load was built using a conventional column stack method in which each case is placed squarely on top of the case below it. The second load was built using a cross stacking method otherwise known as an interlock pattern in which each layer is mirrored 180 degrees from the layer below it. Column stack is known to have superior vertical compression or stacking strength. The cross stacked load is known to have superior stability. The two loads were subjected to ASTM D6055 and a modified version of ISTA 3B at a low ride height of six inches and a high ride height of twelve inches. Each treatment of stacking pattern, obstacle course, and ride height was repeated by three drivers. The study intended to identify a correlation between the obstacle course, ride height, pallet pattern and the resulting containment film force. Film force was measured for each test cycle using a portable film force kit. Similarly the study observed the effects of the factors on a load's tendency to slip during handling. Slippage was measured manually before and after each cycle. Shock was measured throughout the experiment with portable data recorders to quantify the effects of the obstacle courses on the unitized load. 
Table 1: Randomized Column Stack Test Schedule

\begin{tabular}{|c|c|c|}
\hline Driver / Time & Ride Height & Obstacle Course \\
\hline 1 & Low & ASTM \\
\hline 1 & High & ISTA \\
\hline 1 & Low & ISTA \\
\hline 1 & High & ASTM \\
\hline 2 & High & ISTA \\
\hline 2 & High & ASTM \\
\hline 2 & Low & ISTA \\
\hline 2 & Low & ASTM \\
\hline 3 & Low & ISTA \\
\hline 3 & Low & ASTM \\
\hline 3 & High & ISTA \\
\hline 3 & High & ASTM \\
\hline
\end{tabular}

Table 2: Randomized Cross Stack Test Schedule

\begin{tabular}{|c|c|c|}
\hline Driver / Time & Ride Height & Obstacle Course \\
\hline 1 & Low & ISTA \\
\hline 1 & High & ISTA \\
\hline 1 & Low & ASTM \\
\hline 1 & High & ASTM \\
\hline 2 & Low & ISTA \\
\hline 2 & High & ASTM \\
\hline 2 & Low & ASTM \\
\hline 2 & High & ISTA \\
\hline 3 & High & ASTM \\
\hline 3 & Low & ASTM \\
\hline 3 & Low & ISTA \\
\hline 3 & High & ISTA \\
\hline
\end{tabular}




\subsection{Constant Variables}

\section{Table 3: Constant Variables}

\begin{tabular}{|l|l|}
\hline Stretch Wrapper & Highlight Synergy 4 \\
\hline Wrap Pattern & Bottom to Top \\
\hline Top and Bottom Wrap Counts & 2 \\
\hline Pre-Stretch & $200 \%$ \\
\hline Film Force & 7.0 \\
\hline Turntable Speed & 12 RPM \\
\hline Carriage Speed & $45 \%$ \\
\hline Film Type & MP2 0.7 Mil \\
\hline Film Overlap & 4 in. \\
\hline Max Clamp Force & 2500 lbs. of Force \\
\hline
\end{tabular}

\subsection{Constructing the Unitized Loads}

Two unitized loads were used in this experiment. The first load was constructed as a conventional column stack. The second load was a cross (interlock) stack with the middle layer rotated 180 degrees relative to the top and bottom layer. Both loads used in this experiment comprised of top, middle, and bottom layers. Each layer consisted of 15 cases per layer for a total of 45 cases per unitized load.

Table 4: Load Specifications

\begin{tabular}{|l|l|}
\hline Product & Glass Wine Bottles $(750 \mathrm{ml})$ \\
\hline Bottles per Case & 12 \\
\hline Case weight & $29.8 \mathrm{lbs}$. \\
\hline Weight per layer & $450 \mathrm{lbs}$. \\
\hline Load weight & $1300 \mathrm{lbs}$. \\
\hline
\end{tabular}




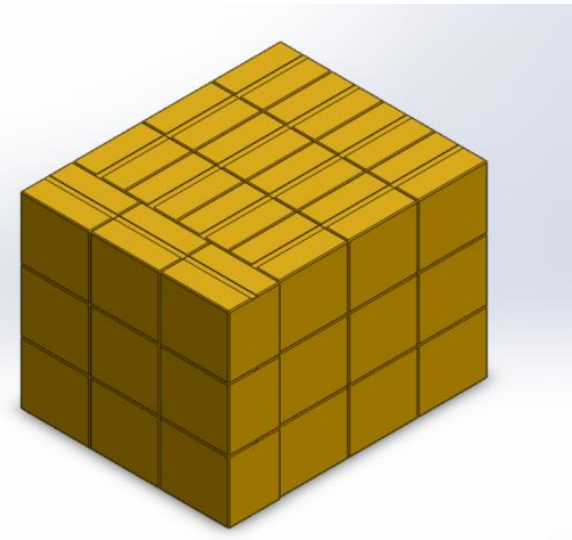

Figure 4: Cross Stacked Unitized Load

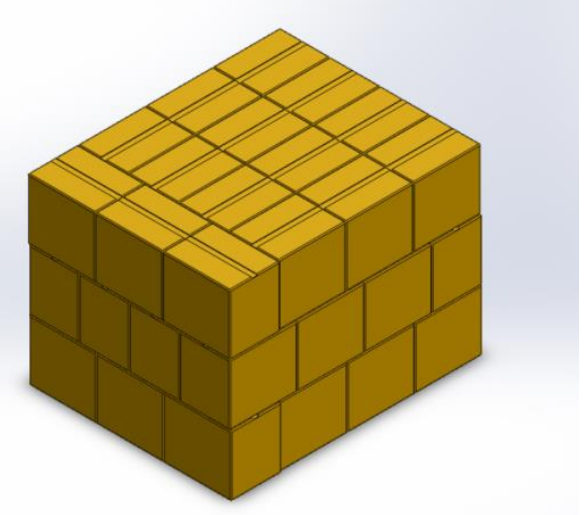

Figure 5: Column Stacked Unitized Load

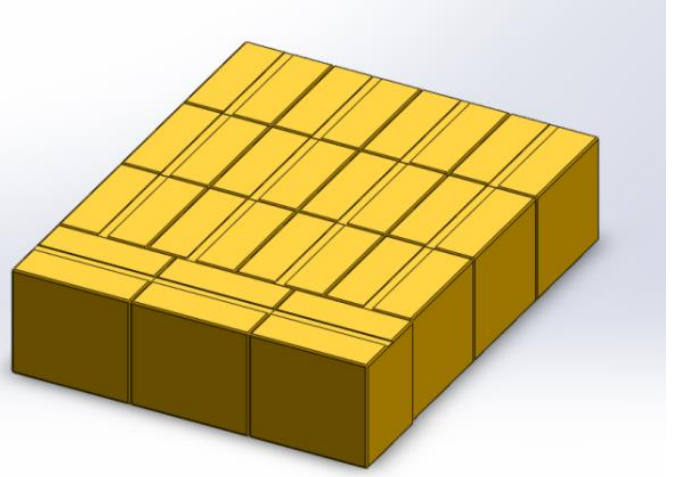

Figure 6: Unitized Load Layer 


\subsection{Shock Data Recorders}

Saver 3X90 data recorders were placed on either side of middle in the top and bottom layer of unitized load. Because there is no geometric middle of the load, the data recorders were placed on either side of mid line of the unitized load as shown below. Using 8020 aluminum framing, a rigid fixture was made for the 3X90 data recorders. The fixture was fabricated to the net size of the inside of inside dimensions of the wine case so that there was no room for the fixture to move and no air gaps. The sensors were placed in the top layer middle, bottom layer middle of the unitized load. For reference a data recorder was fitted to the fork truck rear end via a magnetic mount.

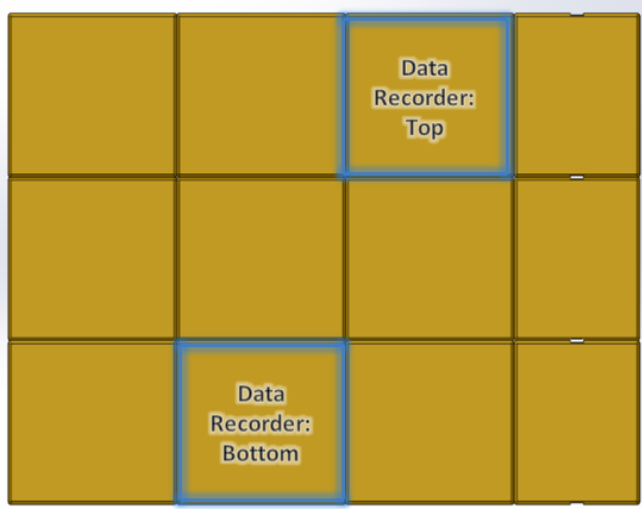

Figure 7: Data Recorder Position Column 


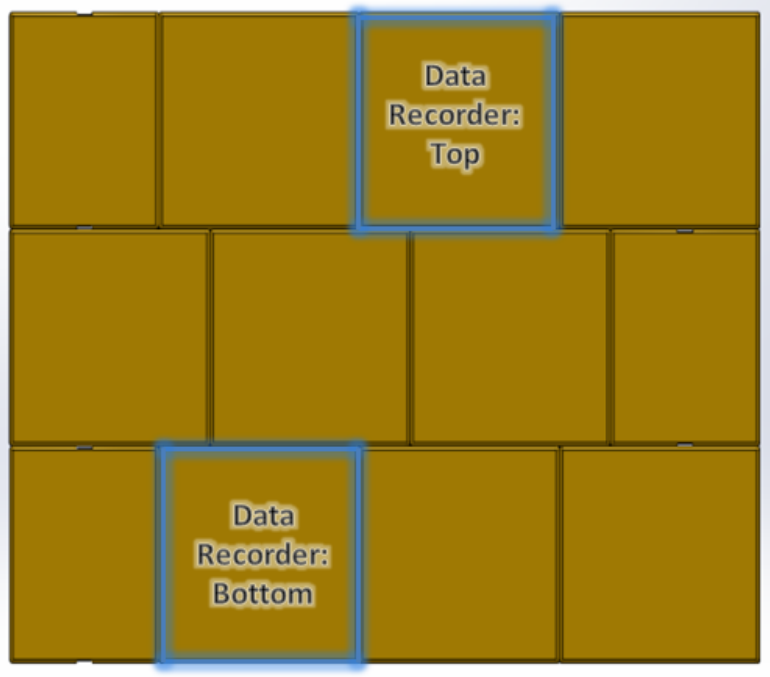

Figure 8: Data Recorder Position Cross

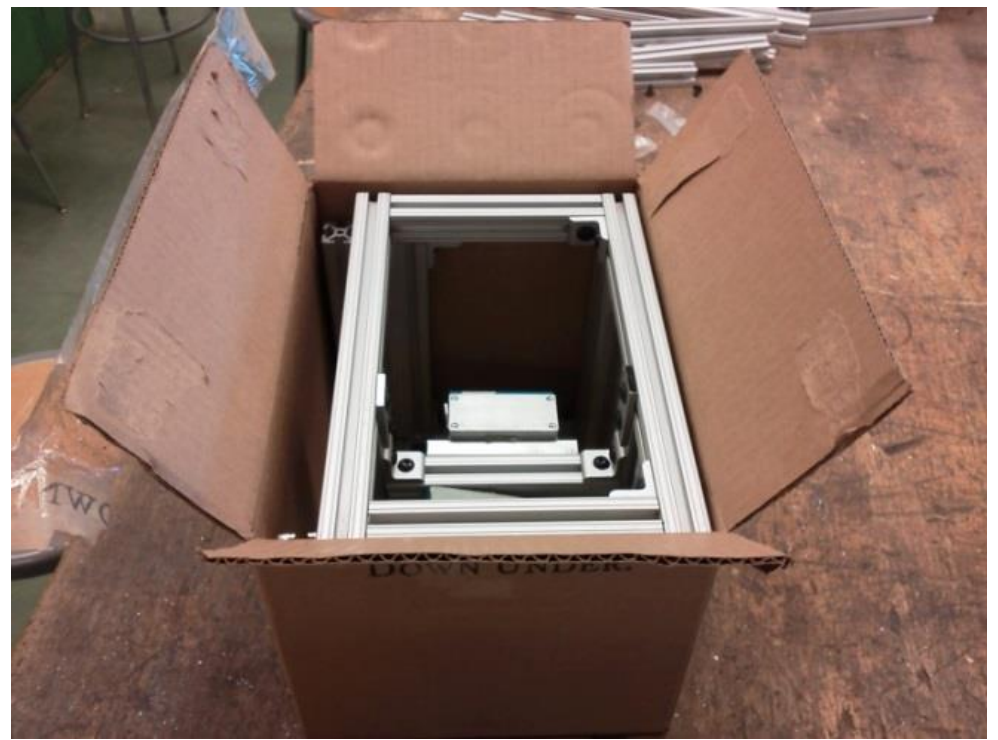

Figure 9: Extruded Aluminum Fixture in RSC 


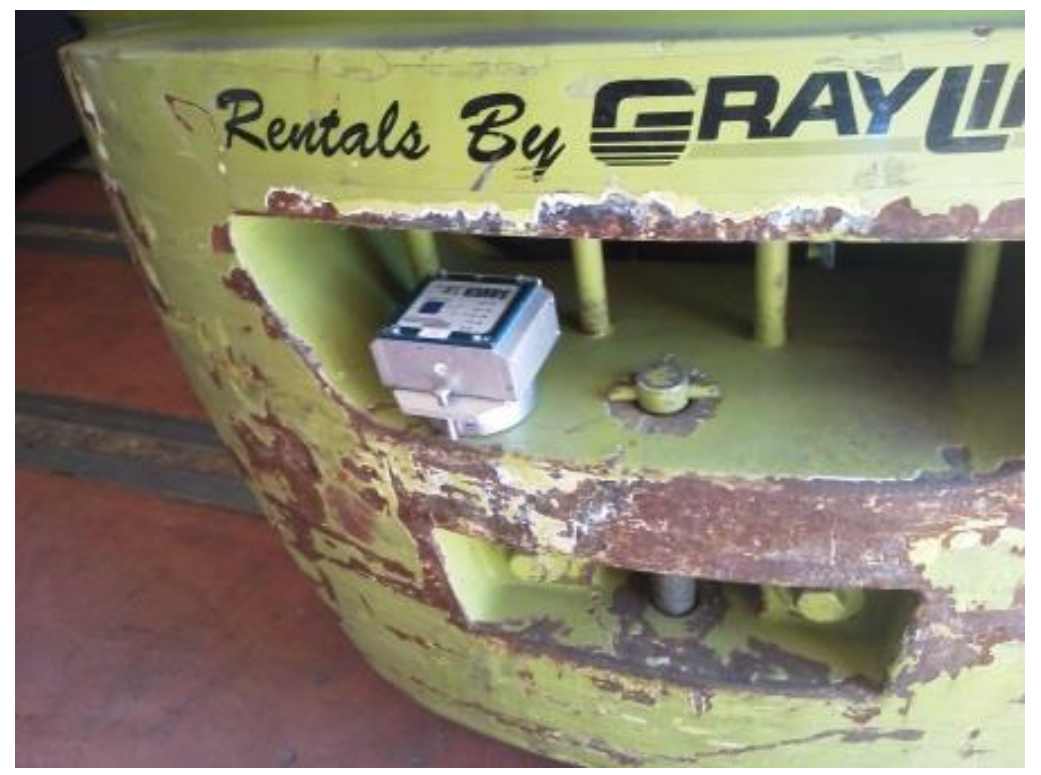

Figure 10: Data Recorder Position Truck

Table 5: Lift Truck Specifications

\begin{tabular}{|l|l|}
\hline Make & Clark \\
\hline Model & C25L \\
\hline Type & LP \\
\hline Serial Number & P2321-0043-9645 KF \\
\hline Weight & $8659+/-432 \mathrm{lbs}$. \\
\hline Capacity & 4200 lbs. \\
\hline Load Center & 24 In. \\
\hline Tire Width & 46.7 In. \\
\hline Tire Type & Pneumatic \\
\hline
\end{tabular}


Table 6: Carton Clamp

\begin{tabular}{|l|l|}
\hline Make & Cascade \\
\hline Model & 25D-CCS-35A \\
\hline Type & MTG II \\
\hline Serial Number & c-215873P \\
\hline Weight & $1,455 \mathrm{lbs}$. \\
\hline Capacity & $2500 \mathrm{lbs}$. \\
\hline
\end{tabular}

Table 7: Data Recorder

\begin{tabular}{|l|l|}
\hline Make & Lansmont \\
\hline Model & Saver 3X90 \\
\hline Accelerometer Type & Triax Piezoelectric \\
\hline Weight & $16.7 \mathrm{oz}$. \\
\hline Trigger Threshold & $1.5 \mathrm{G}$ \\
\hline Duration & $200 \mathrm{~ms}$. \\
\hline
\end{tabular}

Table 8: Load Cells

\begin{tabular}{|l|l|}
\hline Make & Highlight \\
\hline Model & Portable Film Force System \\
\hline Serial Number & MCJ\# 16810 \\
\hline Rating & 0 -100lbs. \\
\hline
\end{tabular}

Table 9: Carton Clamp Force Indicator

\begin{tabular}{|l|l|}
\hline Make & Cascade \\
\hline Rating & $0-6000 \mathrm{lbs}$. \\
\hline
\end{tabular}




\subsection{Construction of the Handling Courses}

\subsubsection{ISTA 3B-2013}

Tools and Equipment:

- (4) Sheets OSB Chip Board (3/4 thickness)

- (10) Steel Plate Obstacles (ISTA 3B 2013)

- (1)Hand Drill Corded or Battery Power $3 / 8$ chuck or $1 / 2$ chuck

- (1)1/2 wood cutting drill bit ( $3 / 8$ or $1 / 2$ shank)

- (1)5/16 Hex Wrench

- (1)15 ft. Tape Measure

- (1)Layout Square

- (1)Carpenters Chalk Line

- (100) Wood Purpose T-Nuts (3/8-16)

- (100) Socket Head Cap Screws (3/8-16)

- (1) Transfer Punch (3/8 diameter)

- (1)Permanent Marker

\section{Description}

ISTA specifies 11 plate obstacles for the 3B handling course. The quantity of obstacles can be reduced from 11 to 10 if the two $\mathrm{C}$ plates are combined into one double plate double wide. The material specified for the hazard plates is CRS (cold rolled steel) or a material with similar density and mechanical properties.[ISTA] Plate A is specified as $1 / 2$ inch thick steel bar stock 2 inches in width and 32 inches in length. Plate B is specified as $1 / 2$ inch thick steel bar stock 5 inches in width and 32 inches in length. Plate $\mathrm{C}$ is Specified as $3 / 4$ inch thick steel bar stock $5 \frac{1 / 2}{2}$ inches in width and 36 inches in length. All drawings indicate multiple $3 / 8$ inch through-holes with corresponding counter-bores to an unspecified diameter and depth. A callout is given for all plate obstacles to round all sharp edges. The rectangular hole-patterns and implied accuracy would necessitate a milling machine or drill press and $\mathrm{X}-\mathrm{Y}$ fixturing for adequate processing. 
Note: Milling thick steel plate necessitates a heavy casting milling machine for acceptable results. For the study, the machining of the steel plate obstacles was outsourced to Central Coast Fabrication. The through holes were counter bored at 9/16 of an inch to a depth of 3/8 of an inch. With this counter bore, the socket head cap screw sits just below the surface of the material. A linear tolerance of +/-.005 inches was held throughout the processing.

\section{Layout and Assembly}

1. Using a tape measure, square, and chalk line, lay out the course on (4) $4 \times 8$ sheets of OSB chip board. Position the plate obstacles as indicated in the ISTA 3B 2013 Standard.

2. Transfer punch the corresponding plate obstacle hole pattern onto the OSB and marked for visibility with a permanent marker.

3. Using a $1 / 2$ inch drill bit, through-drill the corresponding hole pattern into the OSB.

4. Insert 3/8-16 wood purpose T-nuts into the underside of each of the holes.

5. Using 3/8-16 socket head cap screws and a 5/16 hex wrench, fasten the plate obstacles onto the OSB. Note: The T-nuts should be set firmly enough to stay set in the OSB without fasteners, this allows the plates to be removed to facilitate easier transportation and storage. 


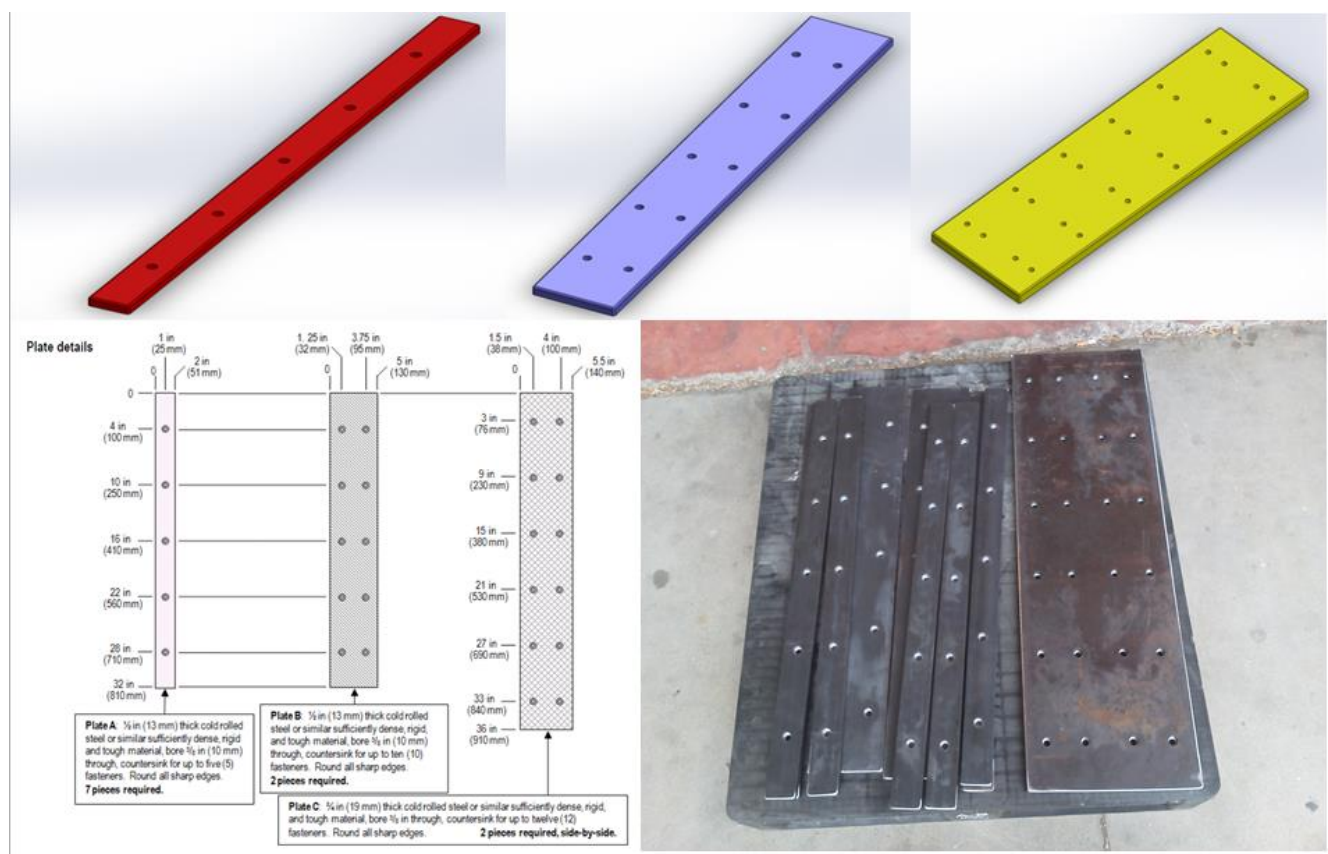

Figure 11: Modeling and Construction of Plate Obstacles

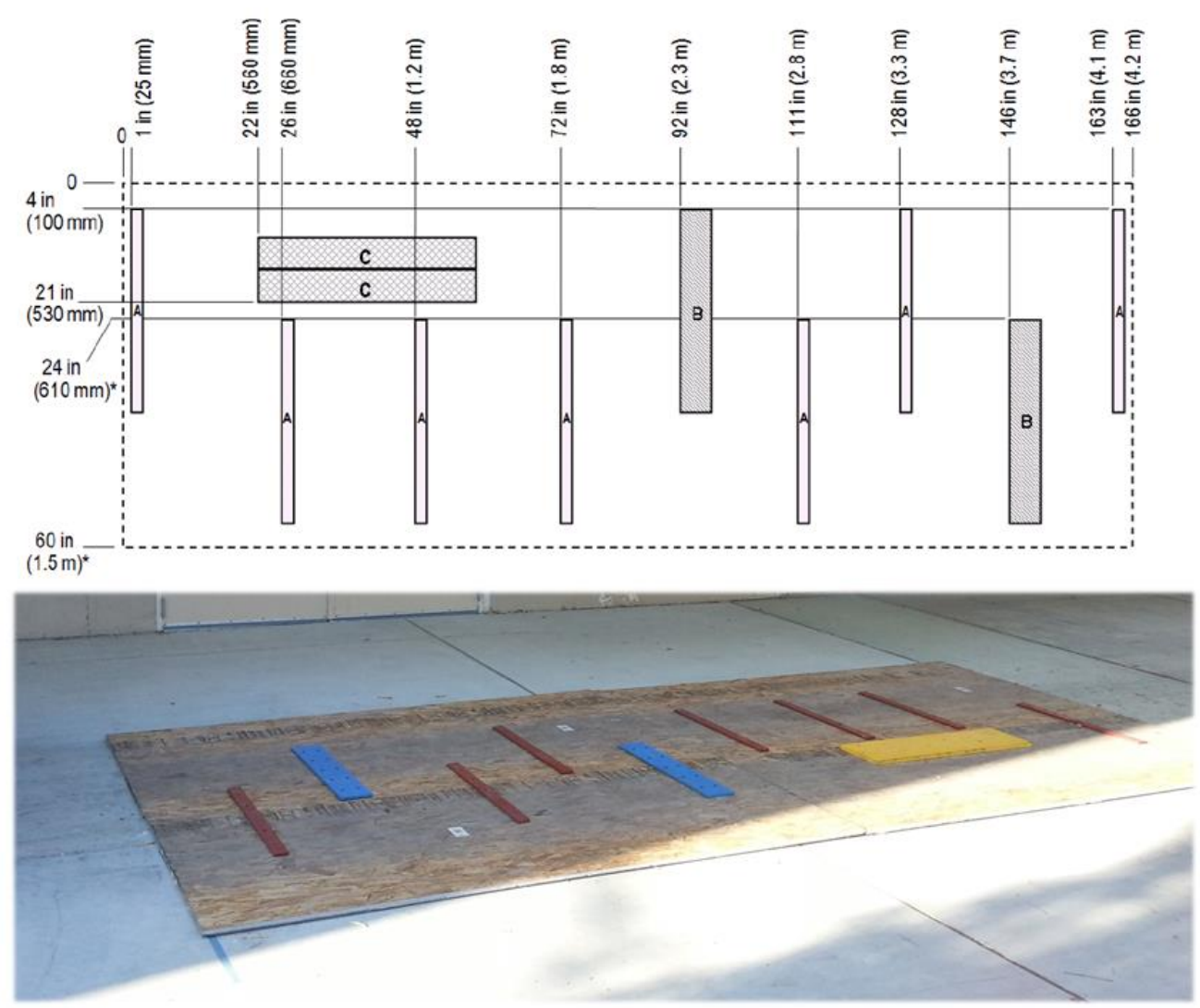

Figure 12: Plate Obstacle Course ISTA 3B-2013 


\subsubsection{ASTM 6055-2013}

\section{Tools and Equipment:}

- Sheets of OSB chipboard (3/4 thickness)

- Lengths of Select Pine Common Board (1x6)

- Chop Saw

- Router Table

- 3/4" 45 Degree Angle Carbide Tipped Chamfer Cutting Bit

- Electric Drill Corded or Battery powered

- \# 1 Screwdriver Hex Bit

- Wood Screws (1 1 $1 / 2$ length)

\section{Description}

In ASTM 6055 the use of hazard obstacles is entirely optional and user defined. The standard specifies however, that if road hazards are to be used, that they should be made of 1 by 6 inch lumber boards. While the length of the board is not specified, obstacles are detailed to have a 45 degree chamfer on both top edges. The depth of the chamfer is not defined in the standard, a cutting depth of $3 / 4$ inch was chosen as it was the maximum depth of cut allotted by the tooling. Select Pine common board was selected for this experiment at lengths of 48 inches. This length was chosen to minimize the possibility of the lift truck only hitting one of the obstacles. When considering the lift trucks wheel span, this method provides a maximum of 48 inches of deviance from center ( 24 inches on either side) without compromising the test results. In an attempt to replicate the test specified as accurately as possible, the obstacle course was laid out exactly as drawn in the ASTM D6055 example with two staggered wooden hazards. 


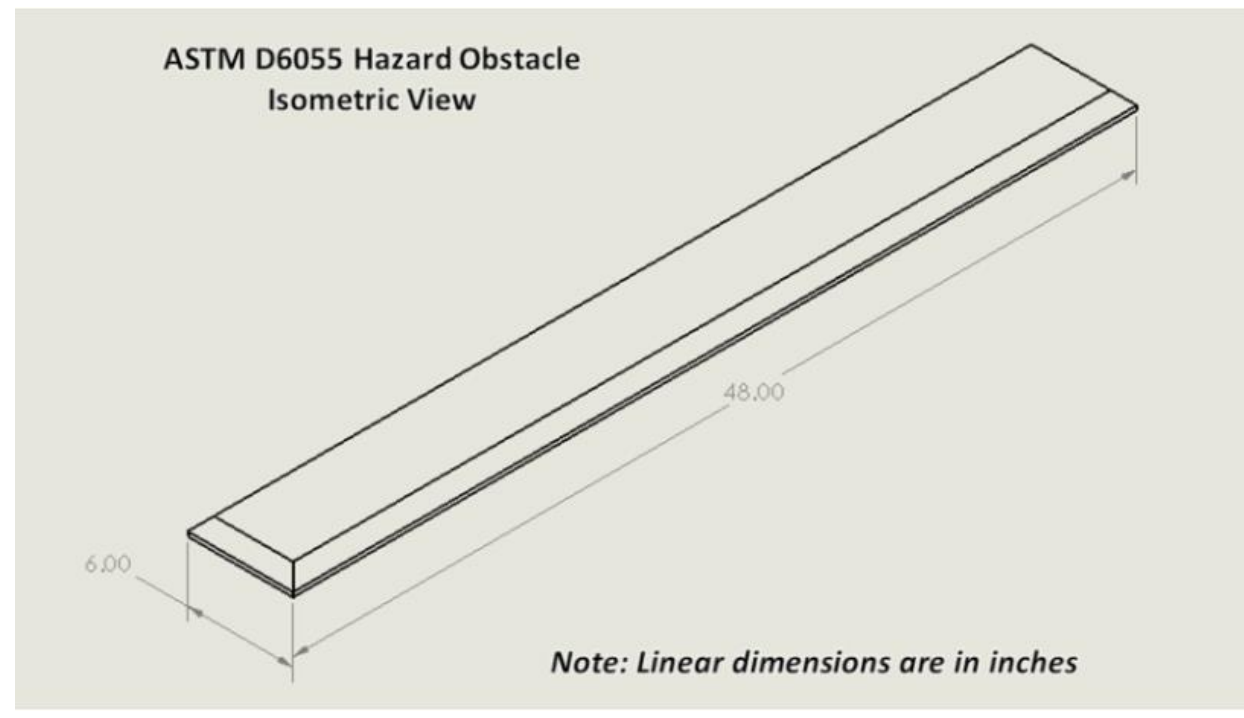

Figure 13: Wooden Obstacle Isometric

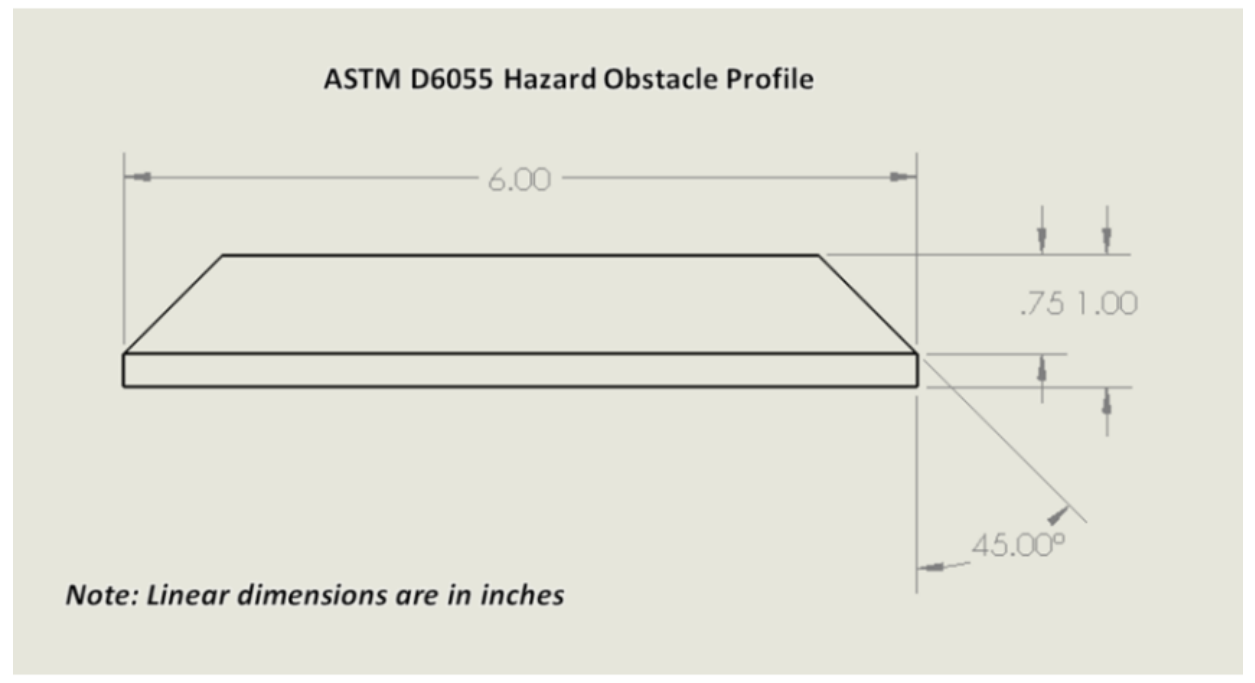

Figure 14: Wooden Obstacle Profile 


\section{Cutting the Wooden Obstacles}

1. Using a chop saw cut the common board to 48 inch lengths. Note: Duplicate obstacles may be desirable for preliminary testing or replacements in the event of severe cracking.

2. Using a router table and $3 / 4$ inch carbide tipped chamfer bit, bevel all edges top edges of the common board obstacle.

Note: The depth of cut should be set to 3/4 inches with a steel rule. Run scrap board until the router table is cutting to the proper depth without a step.

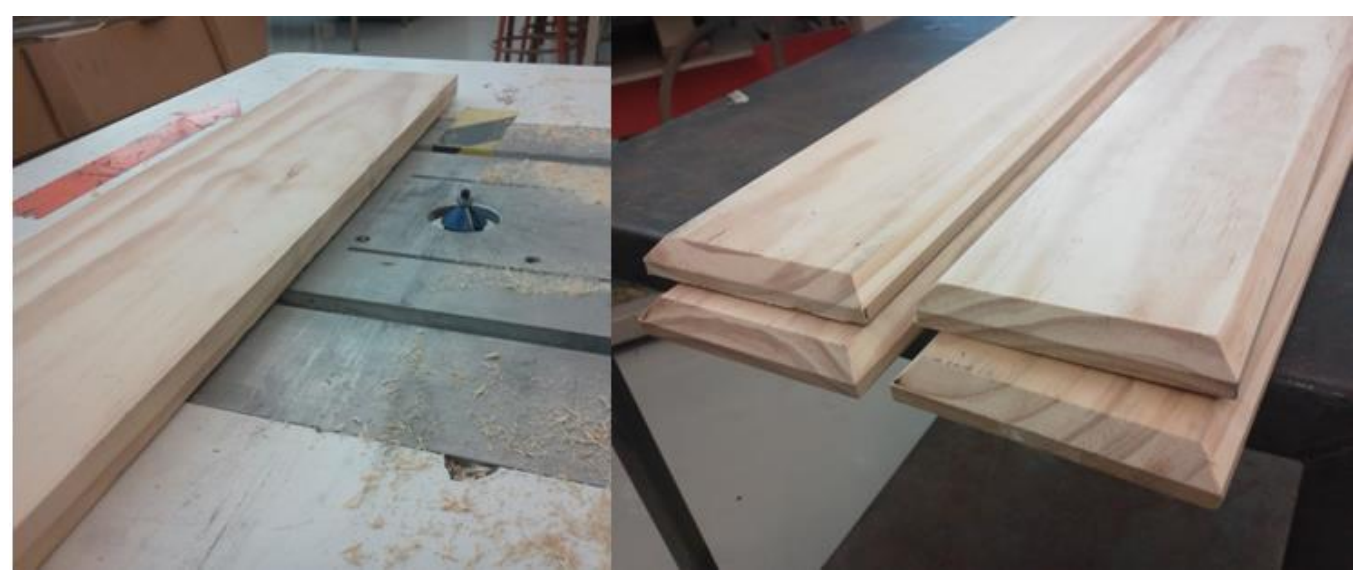

Figure 15: Using Router Table

\section{Layout and Assembly}

3. Using a tape measure, square, and chalk line, lay out the wooden obstacles on two 4 by 8 foot sheets of OSB so that the long side of the obstacle is parralel to the long side of the OSB as shown.

4. With the electric drill, screw driver bit, and wood screws, fasten the wooden obstacles to the two sheets of OSB chipboard. 


\subsection{Portable Film Force System}

The apparatus for measuring film containment force consists of three load cells and a wireless transmitter. The load cells are attached to force plates 6 inches in diameter. The cells are placed to measure film force in the top, middle, and bottom of the unitized load. The load cells are linked with a 2 inch wide length of nylon webbing. To keep the cells in place, three counter weights are attached to the opposite side of the webbing.

\subsubsection{Portable Film Force System Set Up}

1. Attach the main load cell and the two secondary load cells to a length of 2 inch nylon webbing.

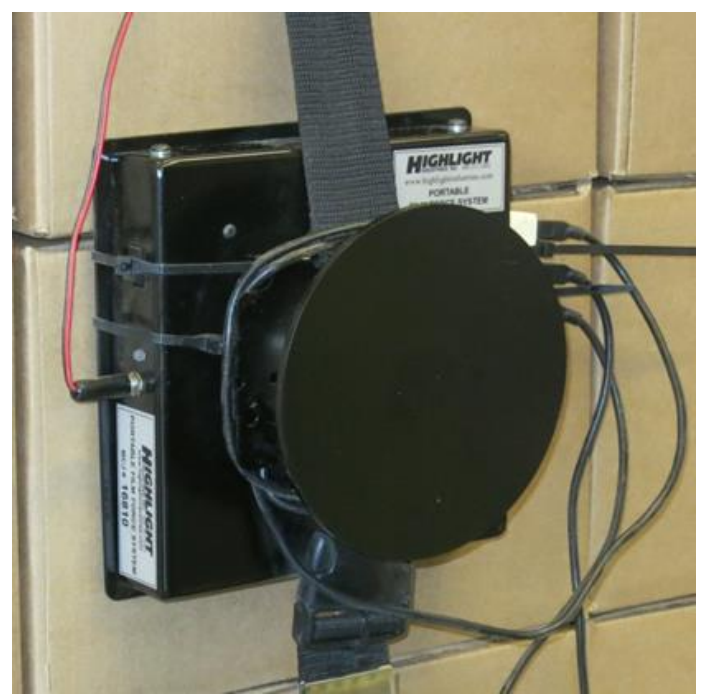

Figure 16: Primary Load Cell

2. Plug the two secondary load cells into the primary load cell via the mini USB cables.

Note: The mini cable attaches via a USB adapter with proprietary circuitry and are required for functionality.

3. Attach three load cell counter weights to the webbing strap with 2 inch buckles. 
4. Drape the three load cells over face 5. Arrange primary load cell so that it is 18 inches inward from the left face of the unitized load, with each load cell centered on the respective case face for top, middle, and bottom.

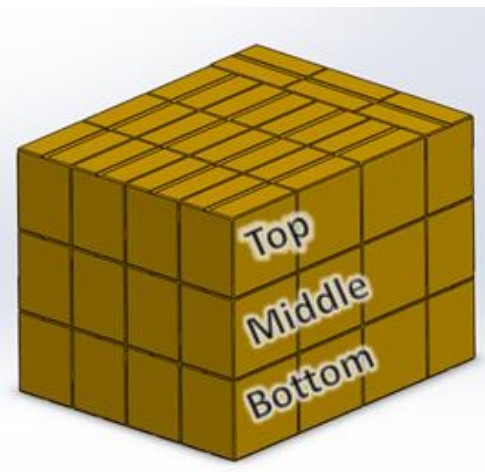

Figure 17: Load Cell Positions

5. Drape attached counter weights over load face.

6. Note: keep the counter weights flat against the unitized load; unseated counterweights may influence the stretch film force.

7. Plug the DC battery charger into the primary load cell and supply power via a 120VAC 15A outlet. Note: an inverter may be used to pull charging power off of the 12 VDC lift truck battery.

8. Turn on primary load cell with the black rocker switch on the top right of the load cell.

9. Using the wireless laptop, connect the software to the load cells with the Launch utility. 


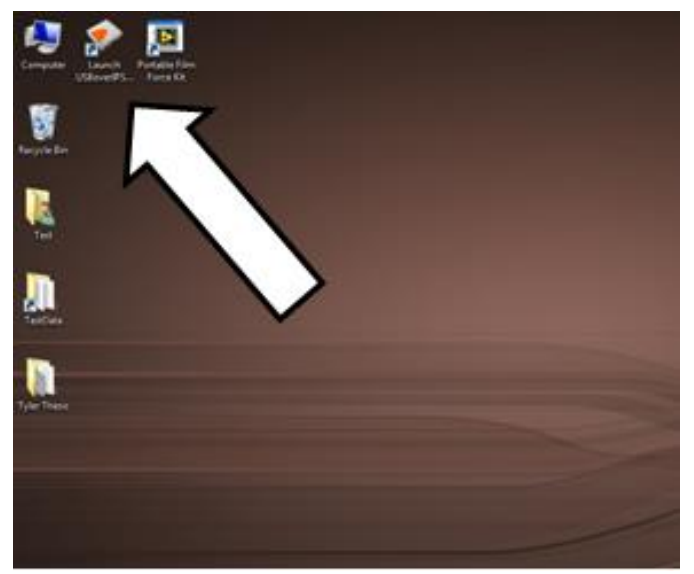

Figure 18: Wireless Launch Utility

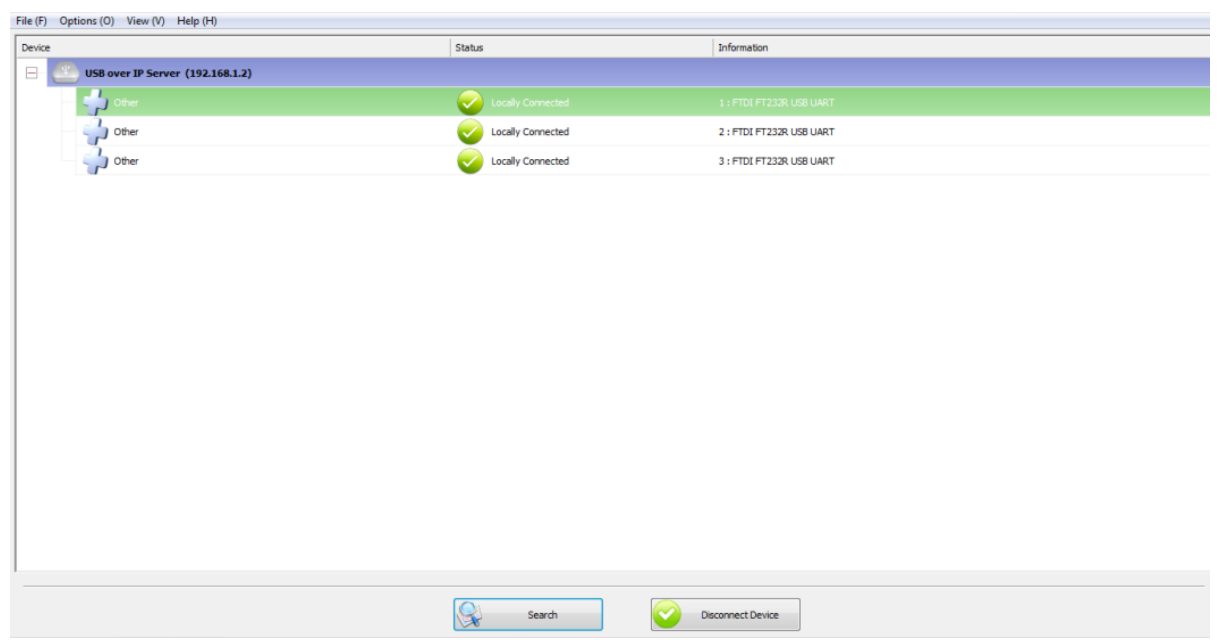

Figure 19: Verifying Communication to Load Cells 
10. Verify that all three load cells are communicating.

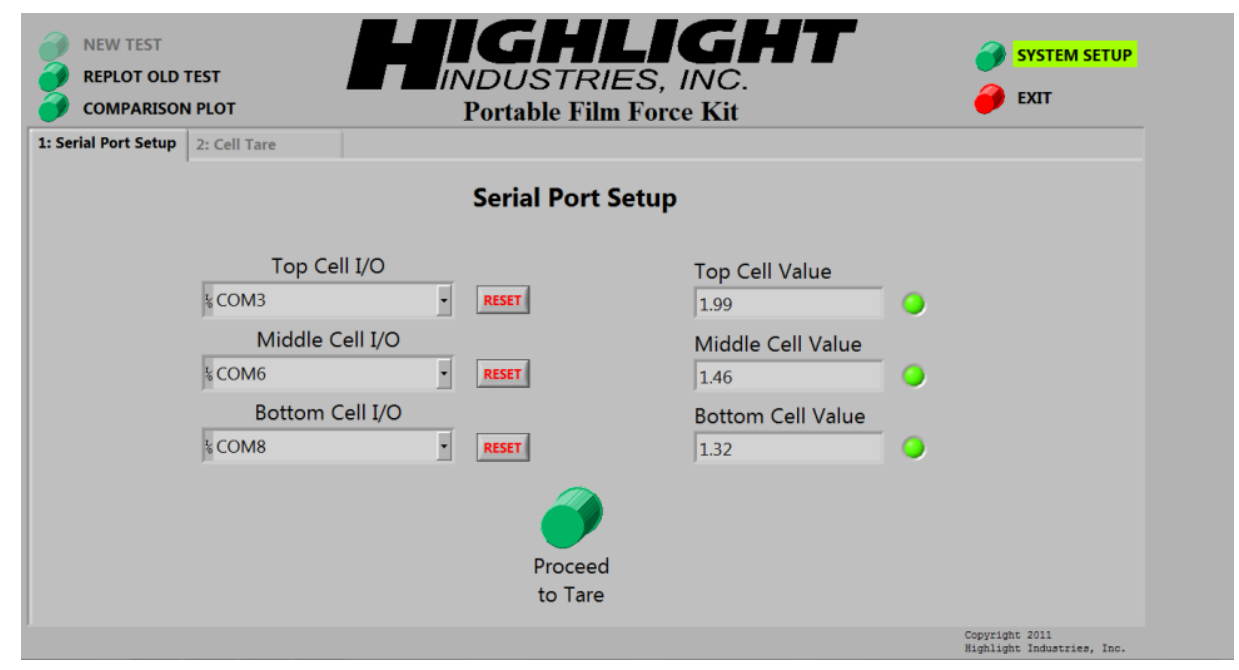

Figure 20: COM Settings

11. In the Highlight software, select the correct COM port for each load cell.

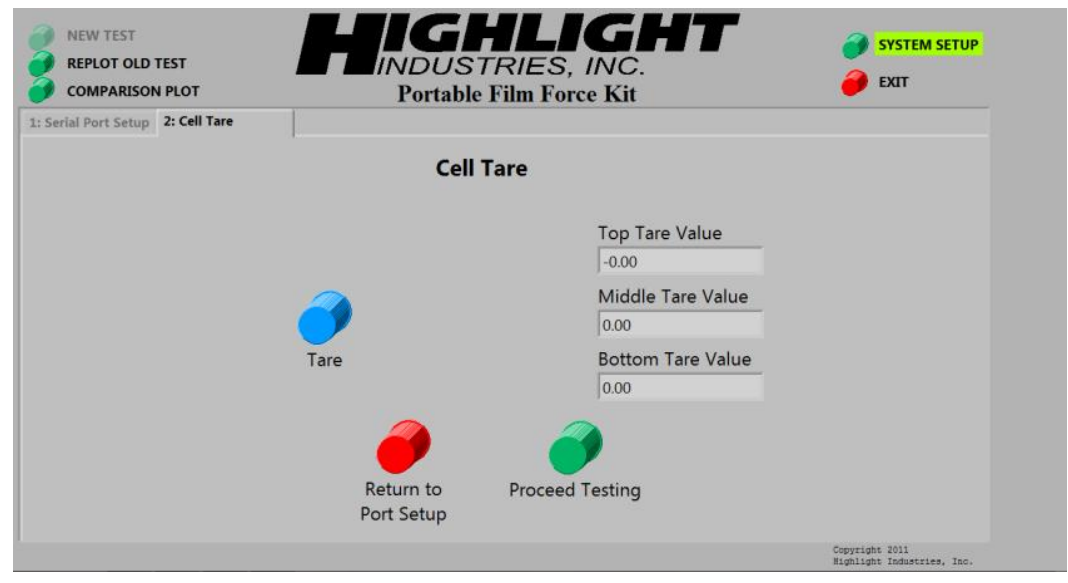

Figure 21: Zeroing the Cells

12. Use the Cell Tare utility to zero the load cells. 


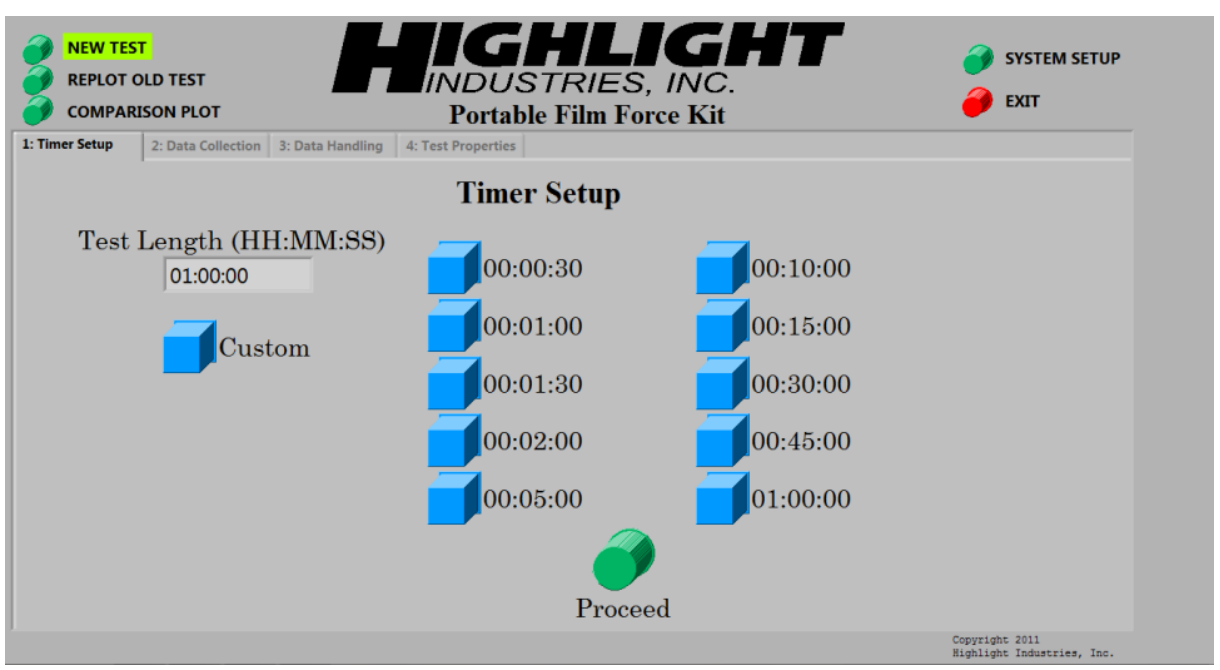

Figure 22: Setting Test Duration

13. Select 1:00:00 for test duration.

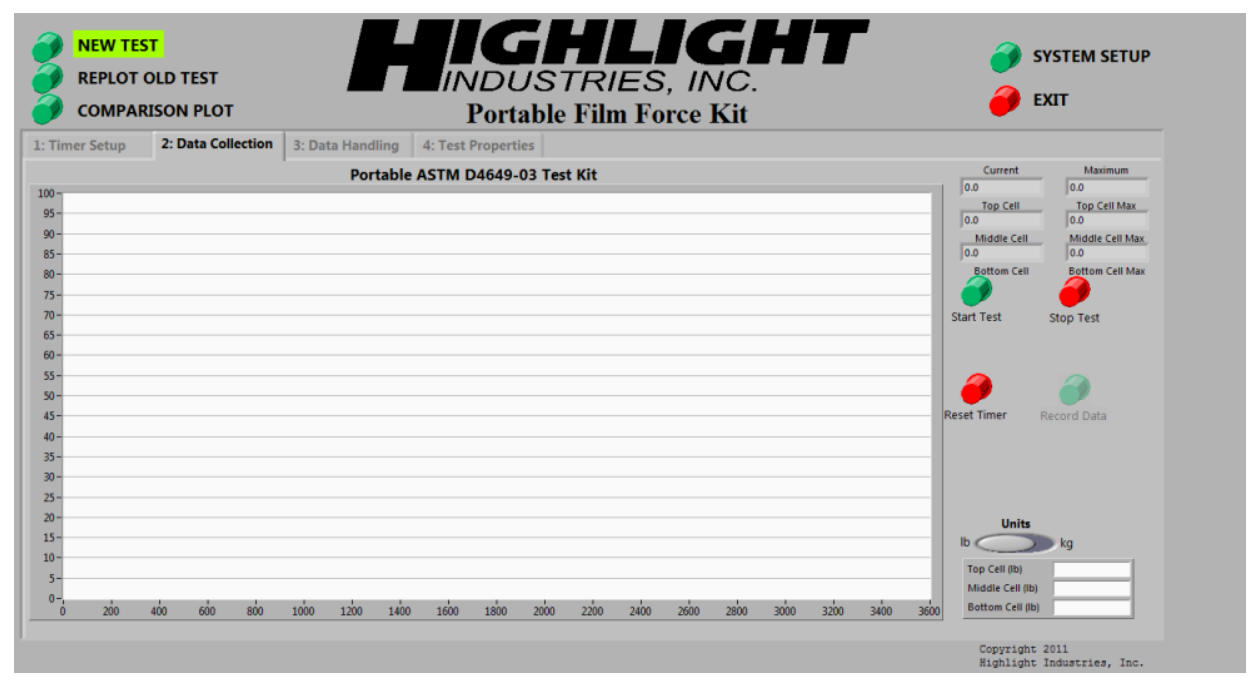

Figure 23: Starting the Test

14. Press Start Test when ready 


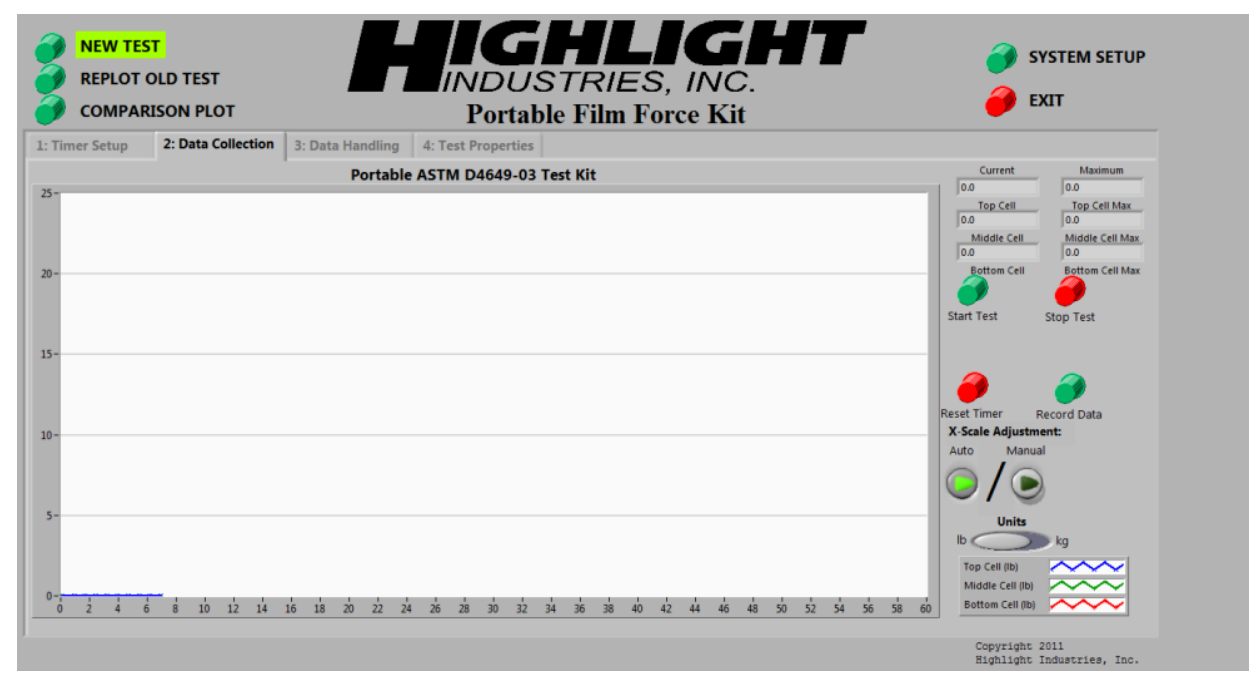

Figure 24: Stopping the Test

15. Press Stop Test when the test is complete

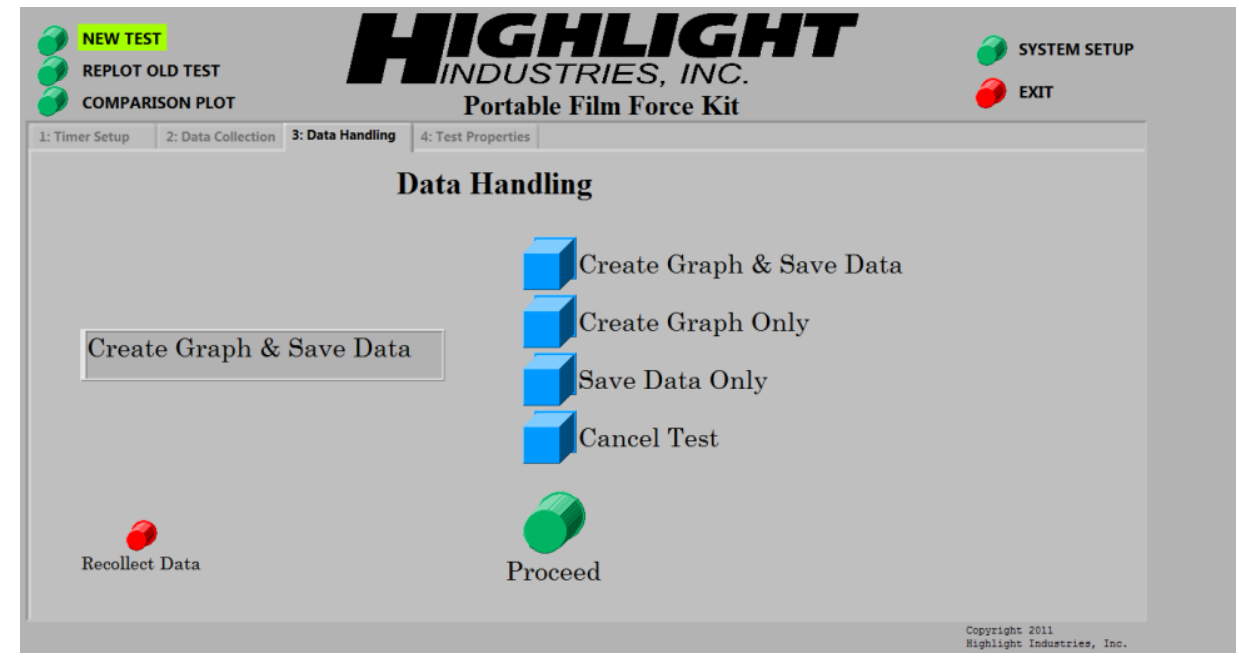

Figure 25: Creating Graph and Saving Data 


\subsection{Disconnecting the Fork Lift Assembly}

1. For this experiment the Cascade Carton Clamp ties into the hydraulic supply for a conventional side shift fork truck mechanism.

2. Both the hydraulic input pressure and return line must be disconnected from the forklift side shift manifold block.

3. A $13 / 16$ open end wrench should be used to turn the hydraulic fittings counterclockwise. Loosen the fittings slowly as residual pressure may be present in the hydraulic lines.

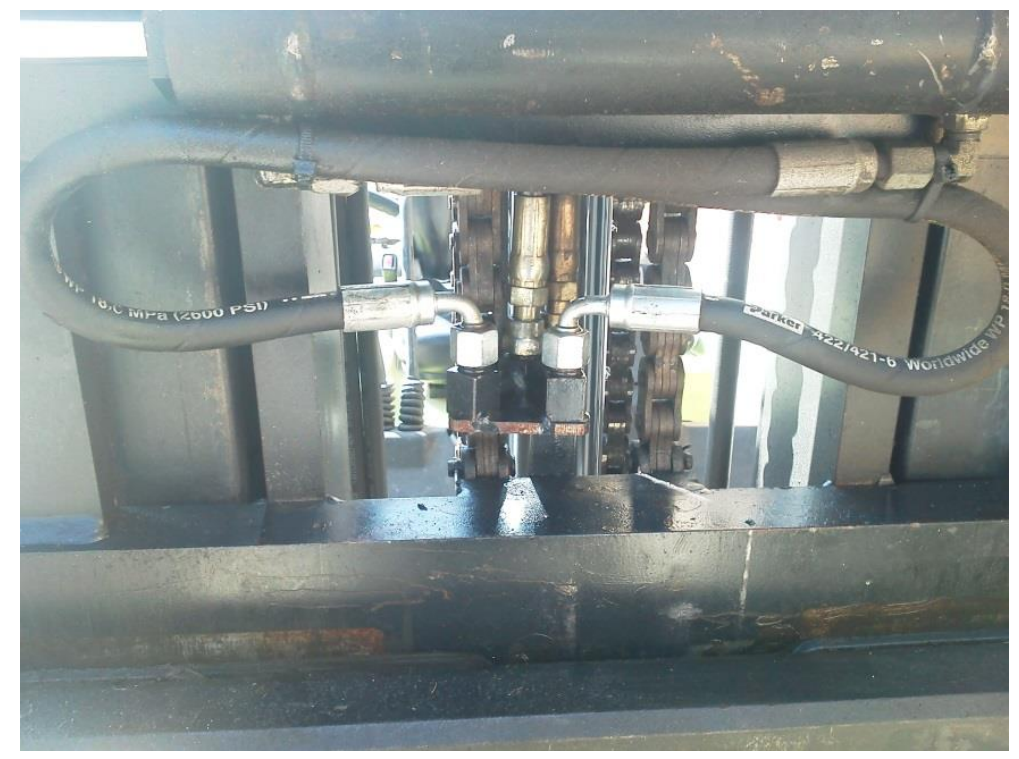

Figure 26: Side Shift Fittings

4. Use a shop rag or similar to wrap the bottom of the fitting as Hydraulic fluid may leak or spray from the fittings.

5. Note: Care should be taken to assure that the internal O-ring seals do not fall off the top male threaded portion of the BC fittings. The hydraulic lines will not seal properly without these two (one per fitting) $O$-rings. 
6. Using a 1" box end wrench or a 1" $1 / 2$ " drive socket, loosen the toe clamps that hold the forklift front end to the mast. To loosen the clamps turn the screws counter-clockwise.

7. Remove the toe clamps from driver and passenger side of the mast.

8. With the toe clamps removed, pull the lowering lever to slowly lower the forklift assembly onto a pallet or similarly elevated and sturdy structure.

9. As the forklift front end lowers onto the pallet, the top most hooks should unseat from the rack.

10. If there is at least $1 / 8^{\text {th }}$ inch of clearance between the rack and the newly unseated forklift attachment the fork truck may be safely reversed and uncoupled from the forks.

11. Using a shop rag, twine, or equivalent, tie the hydraulic input pressure and return lines into a vertical position to prevent residual oil from leaking out of the lines.

\subsection{Attaching the Carton Clamp}

1. The fork truck must be positioned such that the centering pin on the carton clamp assembly mates with the center most notch on the fork truck rack. Note: a second operator is beneficial as the primary operator may have limited visibility while driving the lift truck.

2. With the respective pin and notch aligned, use the raising lever to lift the carton clamp vertically. Note: the top most hooks of the assembly must be completely seated on the rack of the lift truck.

3. With the carton clamp fully seated on the lift truck rack, use a 1" box end wrench or a $1 " 1 / 2 "$ drive socket to fasten the bottom toe clamps to the driver and 
passenger sides of the attachment. Toe clamps must be torqued to approximately 30 ft.-lbs. Safety Note: Jack stands or a sturdy frame should be placed under the clamp assembly to protect the operator in the event of falling.

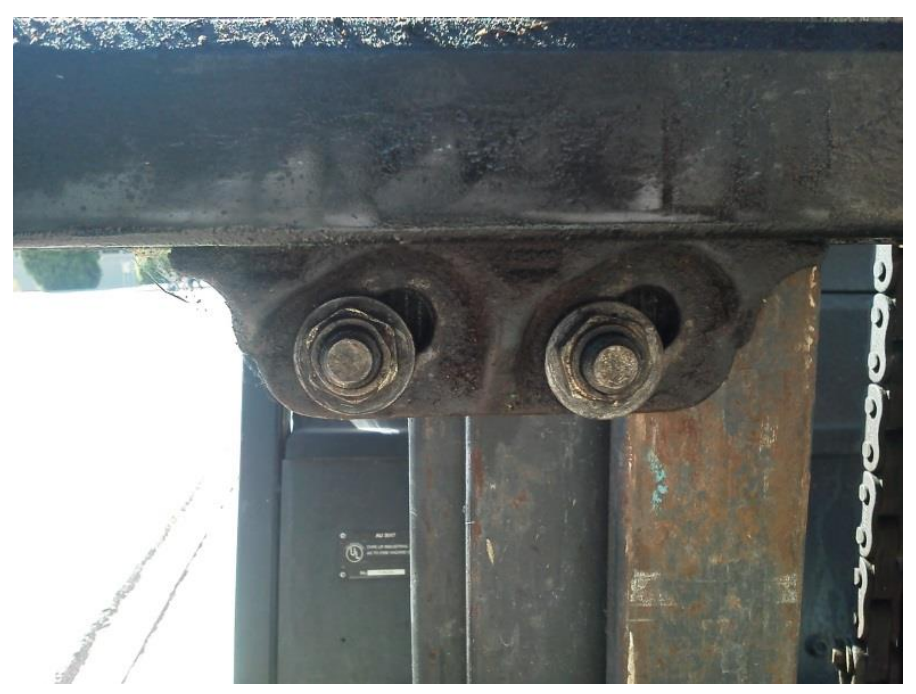

Figure 27: Fork Lift Clamps

4. Using the 13/16 open end wrench, fasten the hydraulic input pressure and return lines to the carton clamp manifold block.

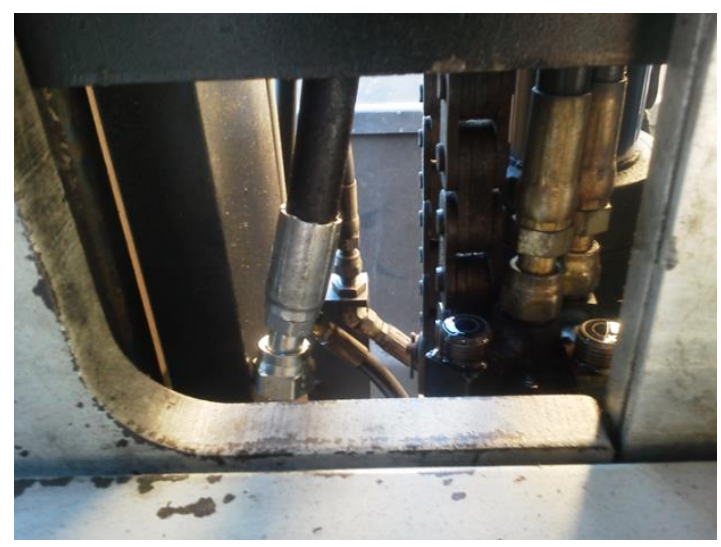

Figure 28: Carton Clamp Connections

5. With the attachment seated correctly in the rack, the toe clamps securely fastened to $30 \mathrm{ft} .-\mathrm{lbs}$. and the side shift hydraulic lines fitted to the carton clamp manifold block, it is now safe to attempt to operate the carton clamp. 
6. Push or pull on the side shift lever on the dash of the fork truck to open and close the carton clamp respectively.

\subsubsection{Adjusting Maximum Clamp Pressure}

1. Start the lift truck in a well-ventilated area and allow the engine temperature to warm to its normal operating temperature.

2. Check the hydraulic fluid levels and verify proper levels on the dipstick.

3. Position the Cascade Clamp Force Indicator as per ASTM D 6055 at the geometric center of the clamping arms.

4. Locate the pressure adjusting screw on the carton clamp manifold block.

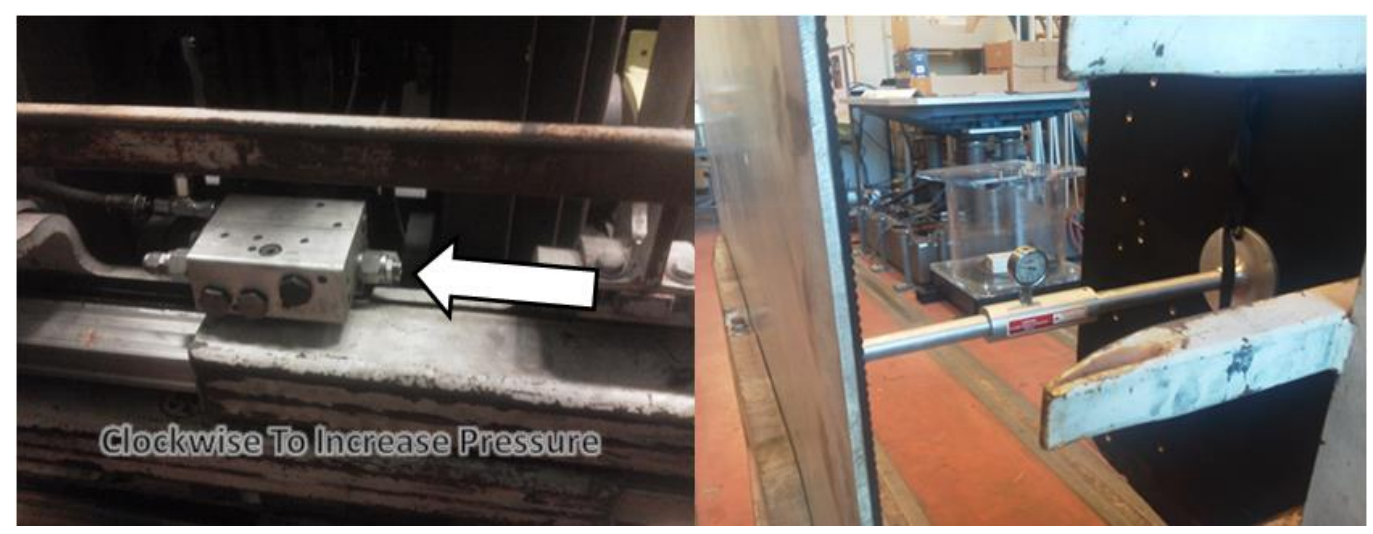

Figure 29: Adjusting Maximum Clamp Force Pressure

5. Using a 5/16 hex wrench, turn the pressure adjusting screw clockwise to increase the maximum clamp force or counter-clockwise to decrease the maximum clamp force. ( Force required is dependent on the size and weight of the load)

6. Using the side shift lever close the carton clamp pads on the force indicator and measure the maximum dial reading. 
Note: Previous studies have shown that a clamping force twice the loads weight should be used for dynamic handling. [Citation]

\subsection{Stretch Wrapper}

1. Locate the power cable and plug it in to a suitable 120VAC, $20 \mathrm{~A}$ outlet. Energize the wrapper by turning the main powers disconnect clockwise. Note: the power disconnect is on the back of the wrapper the side opposite the film carriage.

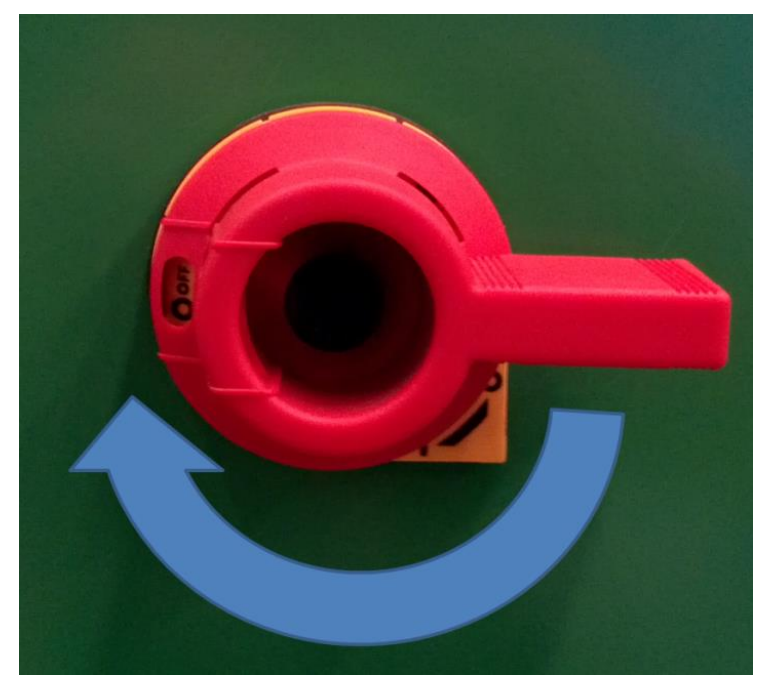

Figure 30: Main Wrapper Power

2. On the control panel, pull the Emergency Stop button fully out and release to clear the Emergency Stop Condition indicated on the Human Machine Interface (HMI)

3. From the main page, select OPERATOR CONTROL SCREEN. 


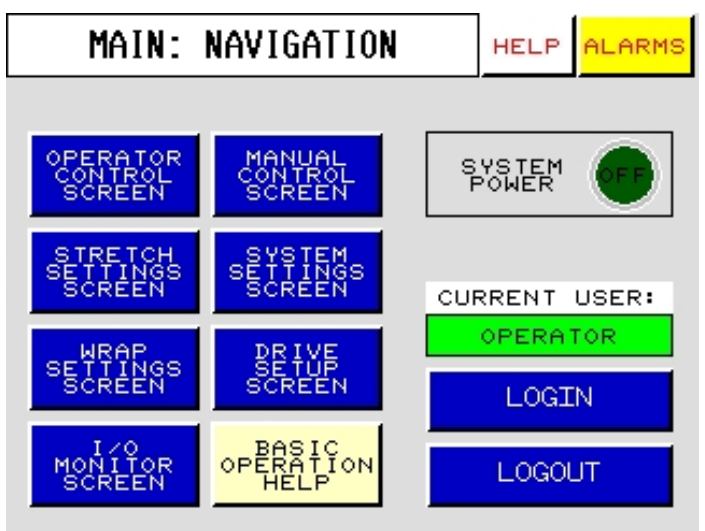

Figure 31: Navigation Screen

4. Use the System Reset button to reset the wrapper drives for use.

5. On the Operator Screen of the HMI select Wrap Pattern 2: BOTTOM WRAPS FIRST

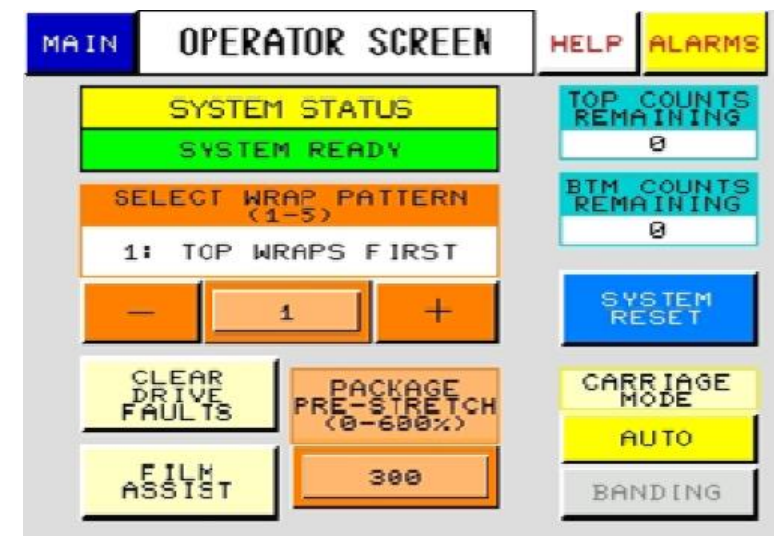

Figure 32: Operator's Screen

6. Set film Pre-Stretch to $200 \%$

7. Set Film Force to 7.

8. On the Operator Screen of the HMI select FILM ASSIST. Film can now be fed from the carriage for 10 seconds.

9. With the film as flat and as low as possible on the unit load, wedge the film tail beneath the left bottom most case and the turn table surface. 
10. With the film tail in position, activate Test Start on the load cell lap top.

11. With the lap top recording data, press CYCLE START on the operator screen to initiate the wrap cycle.

12. Record the Wrap Start time on the data collection sheet.

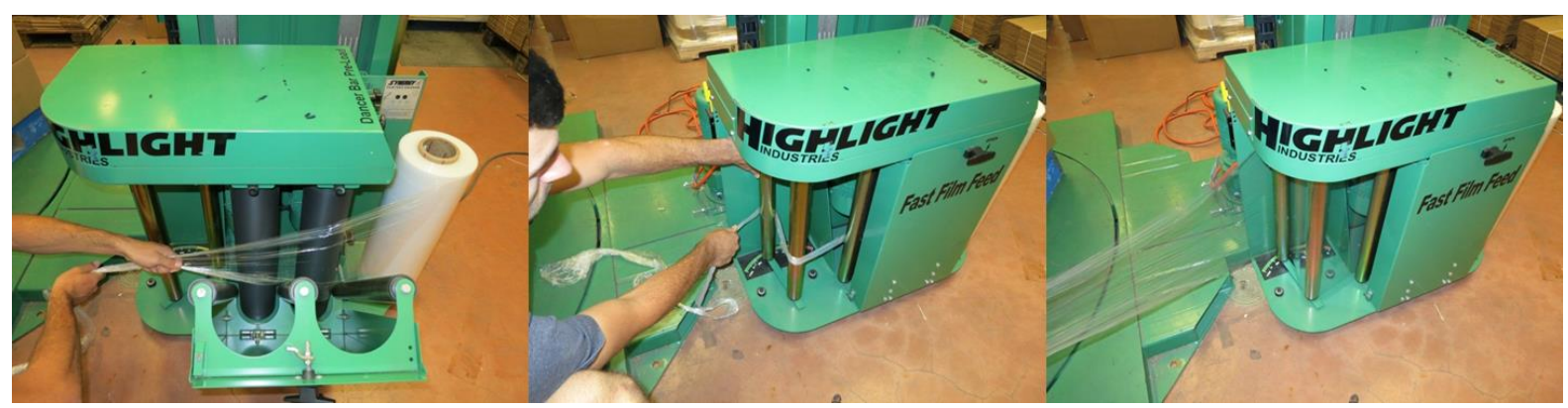

Figure 33: Feeding the Film between Rollers [7] 


\subsection{Handling}

1. Allow the wrapper to finish the wrap cycle.

2. Once the wrap cycle is complete, all the pallet load to sit undisturbed for the next 5 minutes as per ASTM D 4649 [2]

3. After the elapse of 5 minutes the carton clamp should be positioned on both 40 " sides of the unit load with the load cells facing away from the lift truck mast.

4. The unit load should be positioned so that the center of the load is aligned with the

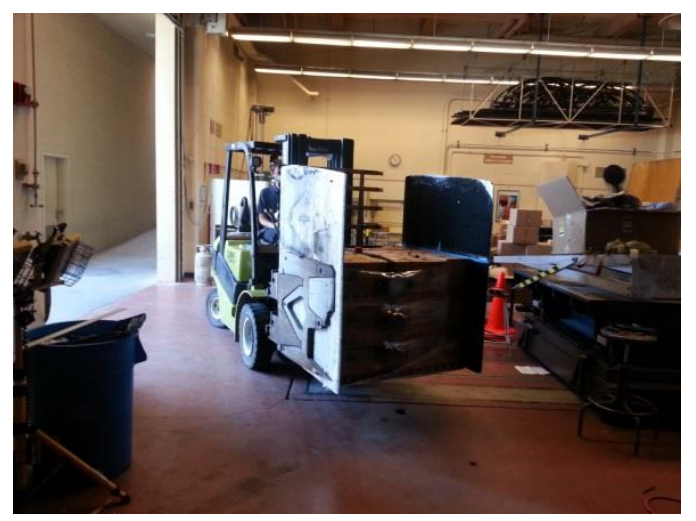

Figure 34: Load Positioning center of the carton clamp pads.

5. The carton clamps should compress the load as low to the ground and as level as possible.

6. Use the side-shift lever to exert the maximum compression force on the product load as was set in section "Adjusting Maximum Clamp Pressure".

7. Record Pick up Time on the data collection sheet.

8. Elevate the load so that the bottom is not dragging on the stretch wrapper turn table.

9. Back up the lift truck from the wrapper and proceed to the specified route.

10. The film force laptop must stay within 30 yards of the lift truck at all times. 


\subsection{ISTA 3B Handling Course}
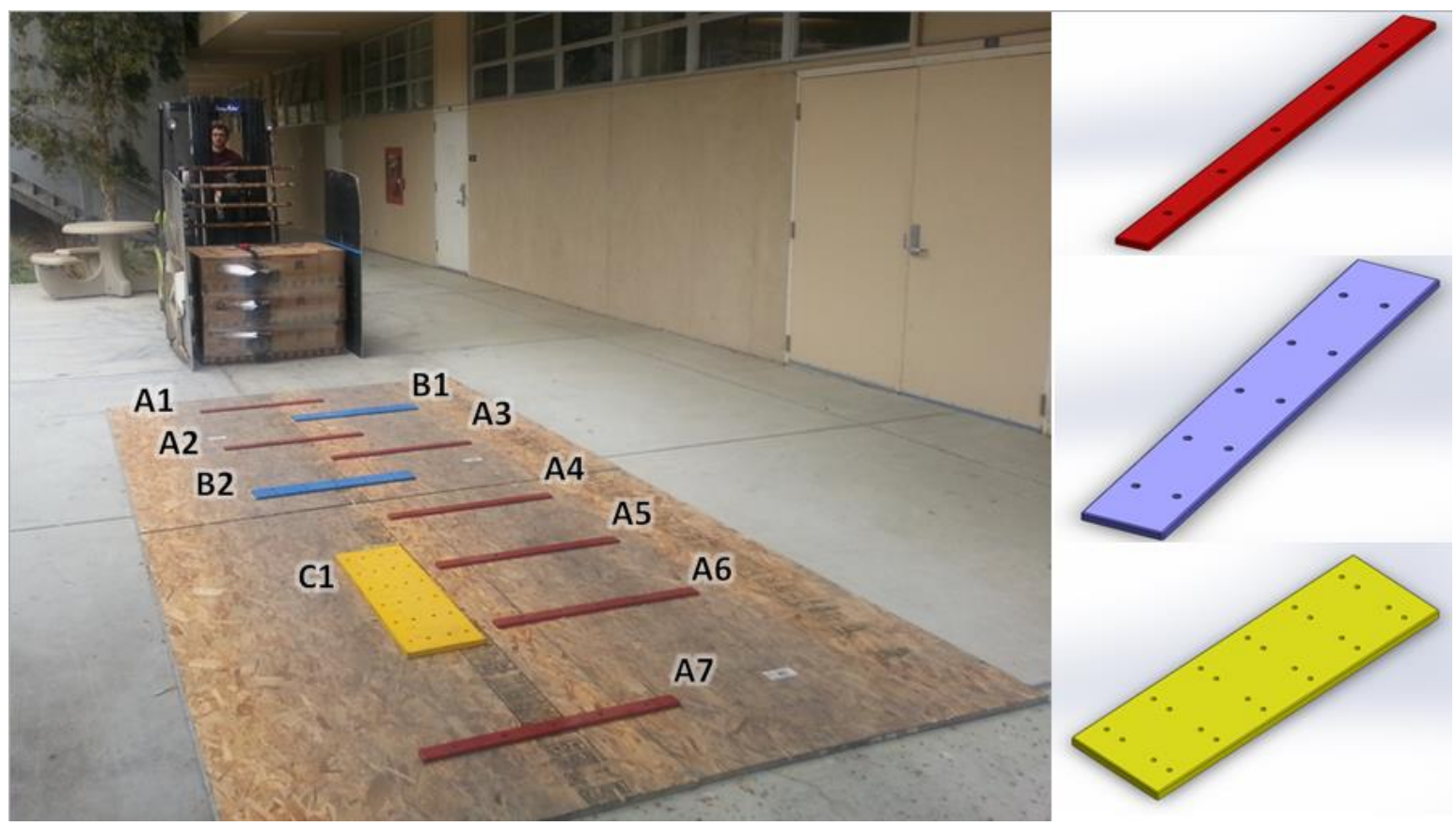

Figure 35: ISTA 3B-2013 Course with Plate Obstacles Identified

\section{Description}

The 3B handling course as it is written was not intended for carton clamp handling. It is designed to simulate the effects of handling using a conventional fork truck apparatus. Preliminary testing revealed that even at a velocity less than $1 \mathrm{~m} / \mathrm{s}$ the clamp truck was unable to retain the unitized load. The bottom layer of the unitized load began to dislodge before the specified four repetitions could be completed. The test procedure was shortened to one forward traverse of the obstacle course and one rearward traverse of the obstacle course. This abbreviated test methodology provided consistent load retention. Likewise, the test standard suggests that the plate obstacles be bolted into the ground to prevent the plates from moving during testing. The plate obstacles were fitted to (4) 4 by 8 foot sheets of $3 / 4$ inch OSB flake board. The construction of these sheets is detailed in 
section Construction of The Handling Courses. With the weight of the fork truck atop the boards the plate obstacles cannot move relative to one another.

1. Position the carton clamp assembly approximately 10 yards in front of plate obstacle A1.

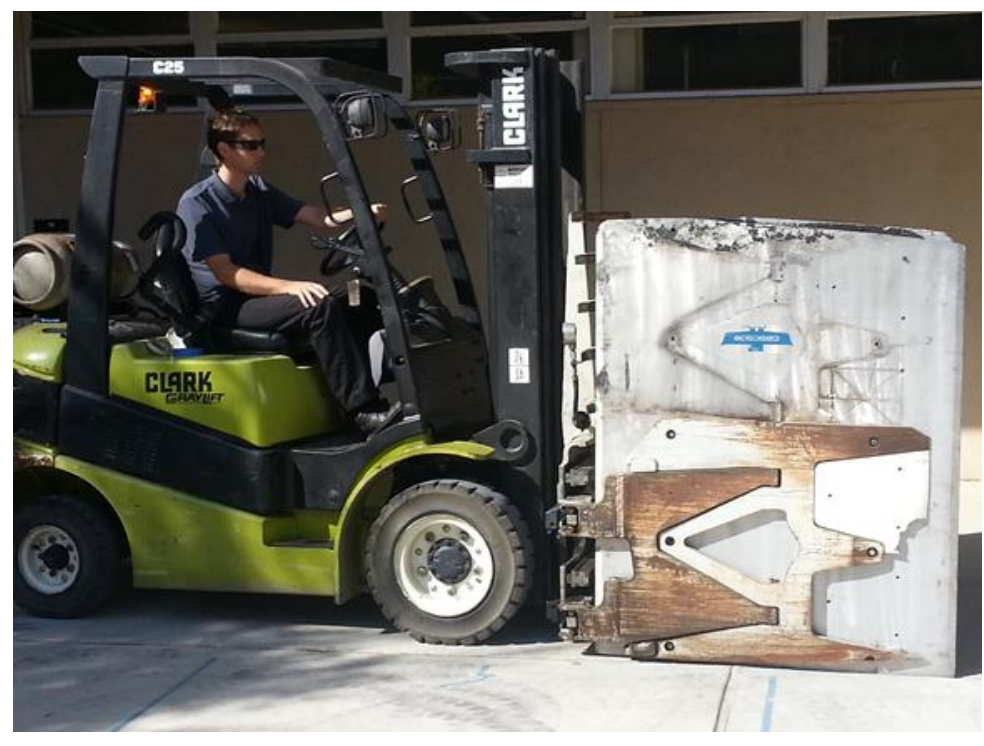

Figure 36: ISTA 3B-2013 Start Position

2. Set the unit load ride height depending on the treatment needed as indicated in the test schedule. 


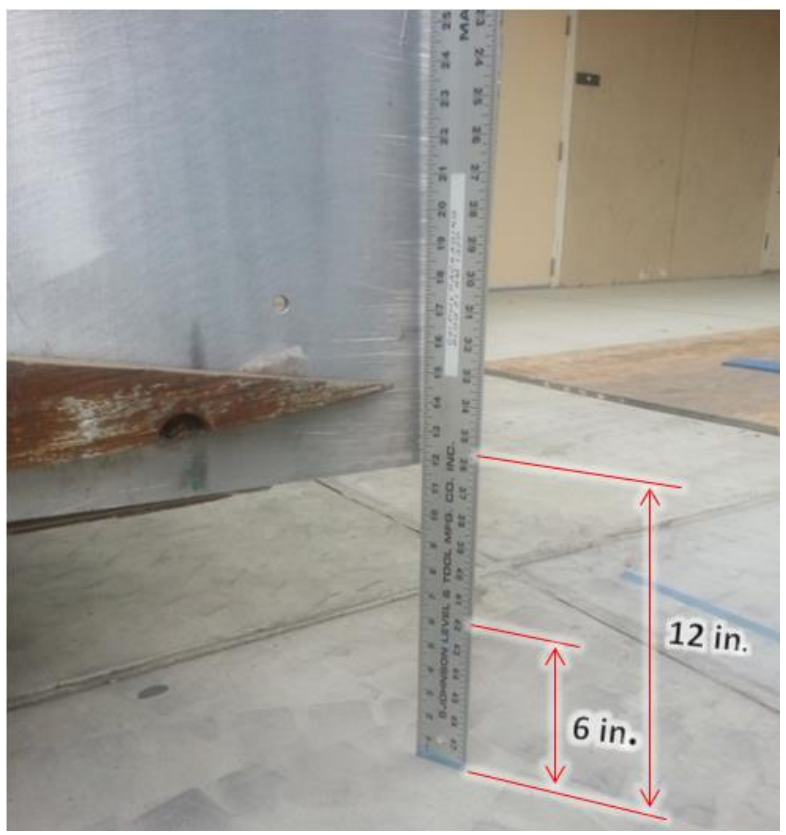

Figure 37: Setting the Correct Ride Height

3. Measure the unit load in the back, middle, and front in reference to the top of the driver side clamp pad.

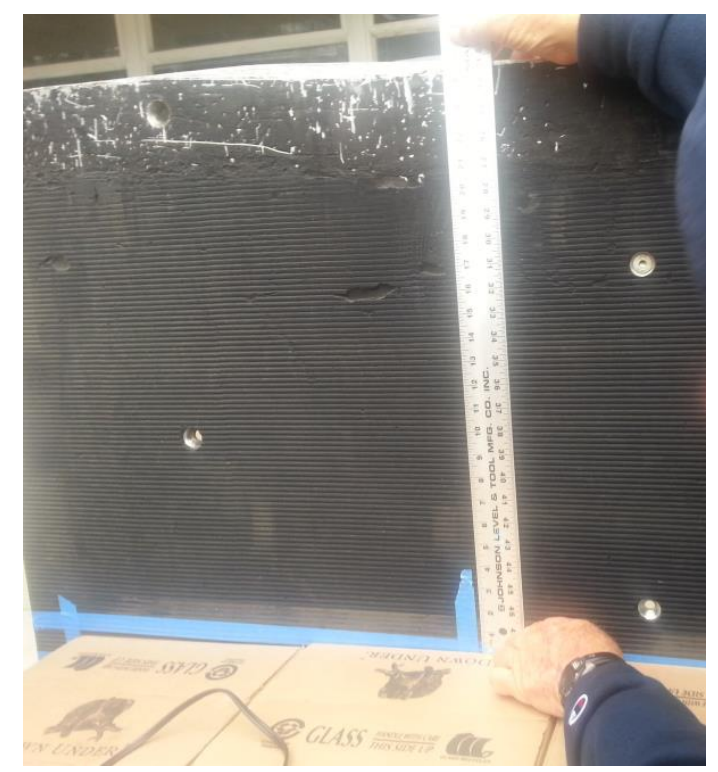

Figure 38: Measuring Load Position between Clamp Pads 
4. Using the 1 meter tape lines on the ground, establish a velocity of approximately $1 \mathrm{~m} / \mathrm{s}$.

5. Proceed over the plate obstacles while maintaining a safe velocity not to exceed 1 $\mathrm{m} / \mathrm{s}$.

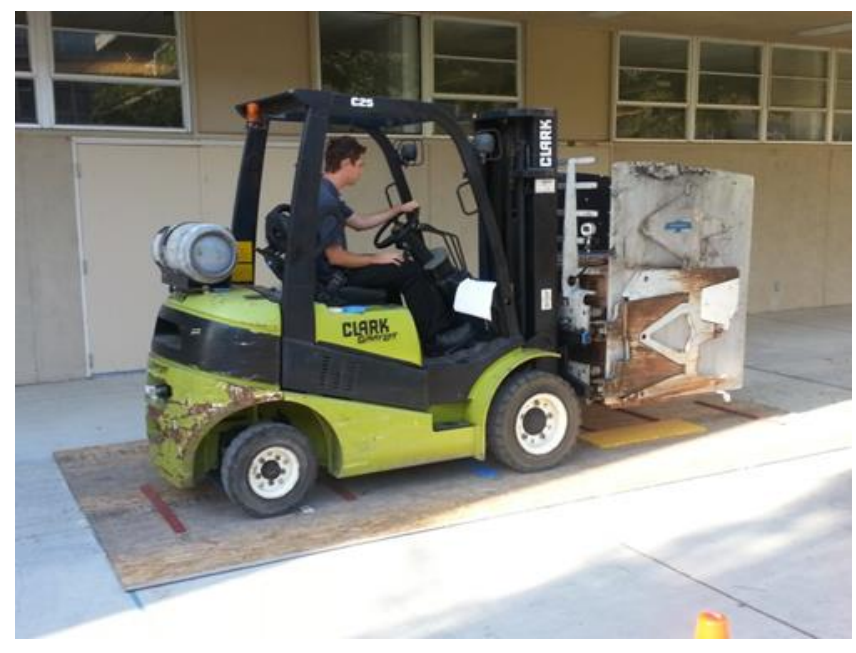

Figure 39: Progression through Obstacle Course

6. Stop the lift truck after the rear wheel has cleared the last plate obstacle (A7).

7. Reverse the lift truck and proceed over the plate obstacles backwards until the fork truck returns to its original starting position. 


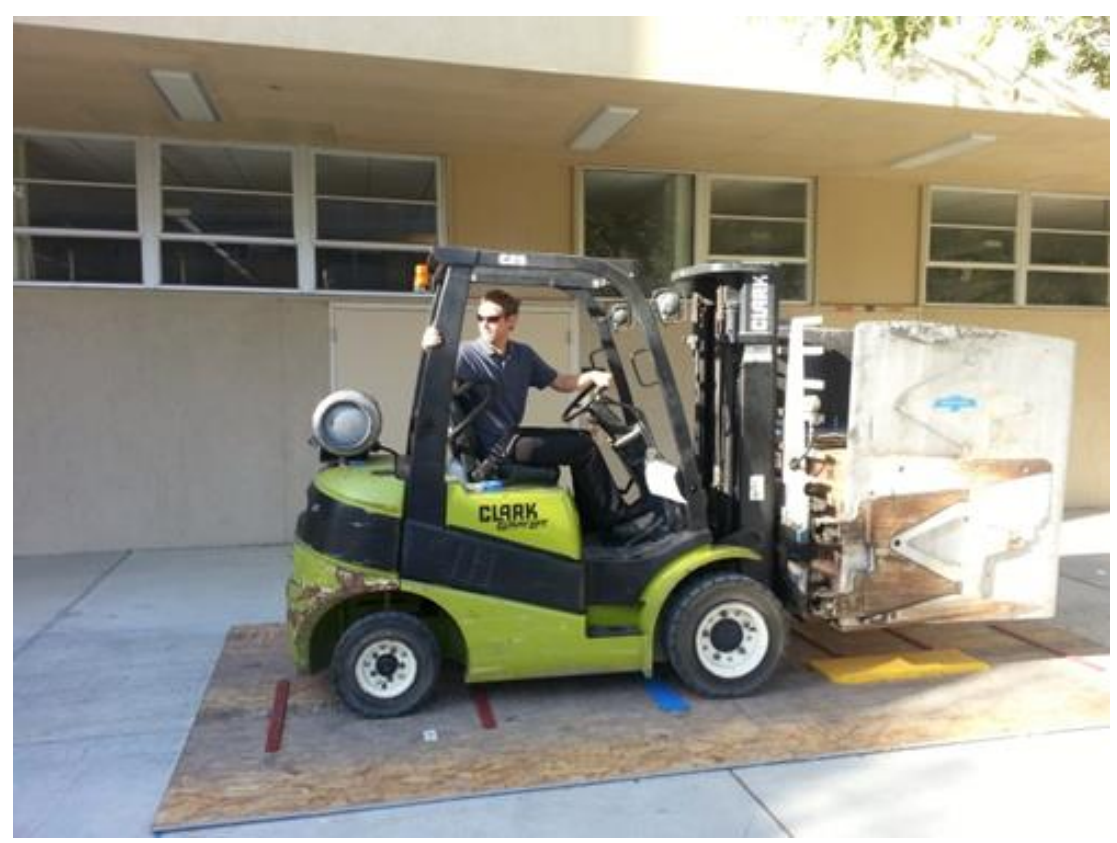

Figure 40: Reverse

8. Measure the unit load in the back, middle, and front in reference to the top of the driver side clamp pad.

9. Set the unit load down on level ground and allow the stretch film to relax undisturbed for 5 minutes.

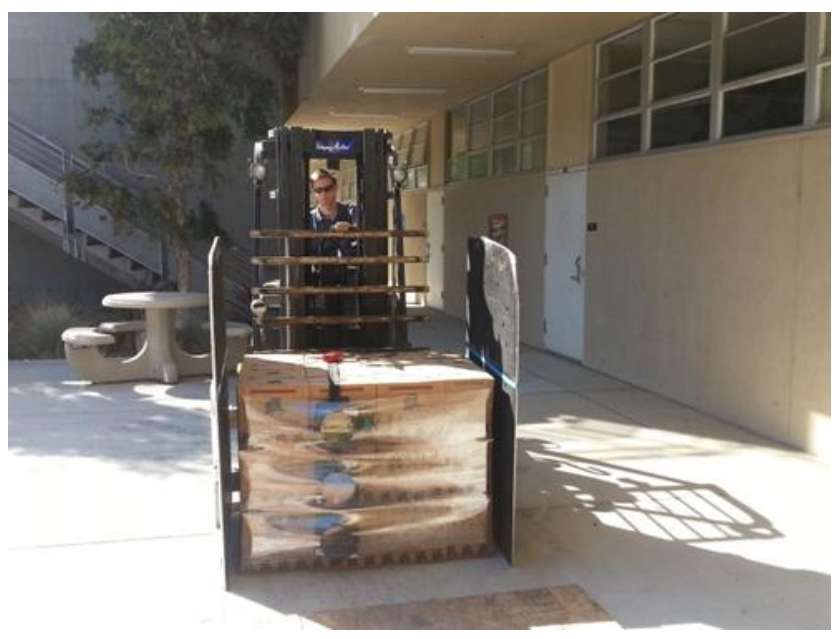

Figure 41: Relax Time 
10. Record Relax Time on the data collection sheet.

\subsection{ASTM D6055-2013 Handling Course}

The driving course specified in ASTM D6055 allows the user to specify the quantity and intensity of the road obstacles. According to the standard, the obstacles can be omitted entirely. The obstacle course used in this study replicates the obstacle course as drawn in the ASTM D6055 standard. Due to the constraint of adequately smooth concrete, the obstacles have been shifted to the far end of OP 2 for maximum acceleration and

deceleration room. The plate obstacles were fitted to (2) 4 by 8 foot sheets of $3 / 4 \mathrm{in}$. OSB chip board. The construction of these sheets is detailed in section Construction of The Handling Courses. With the weight of the fork truck atop the boards, the wooden obstacles cannot move relative to one another. 


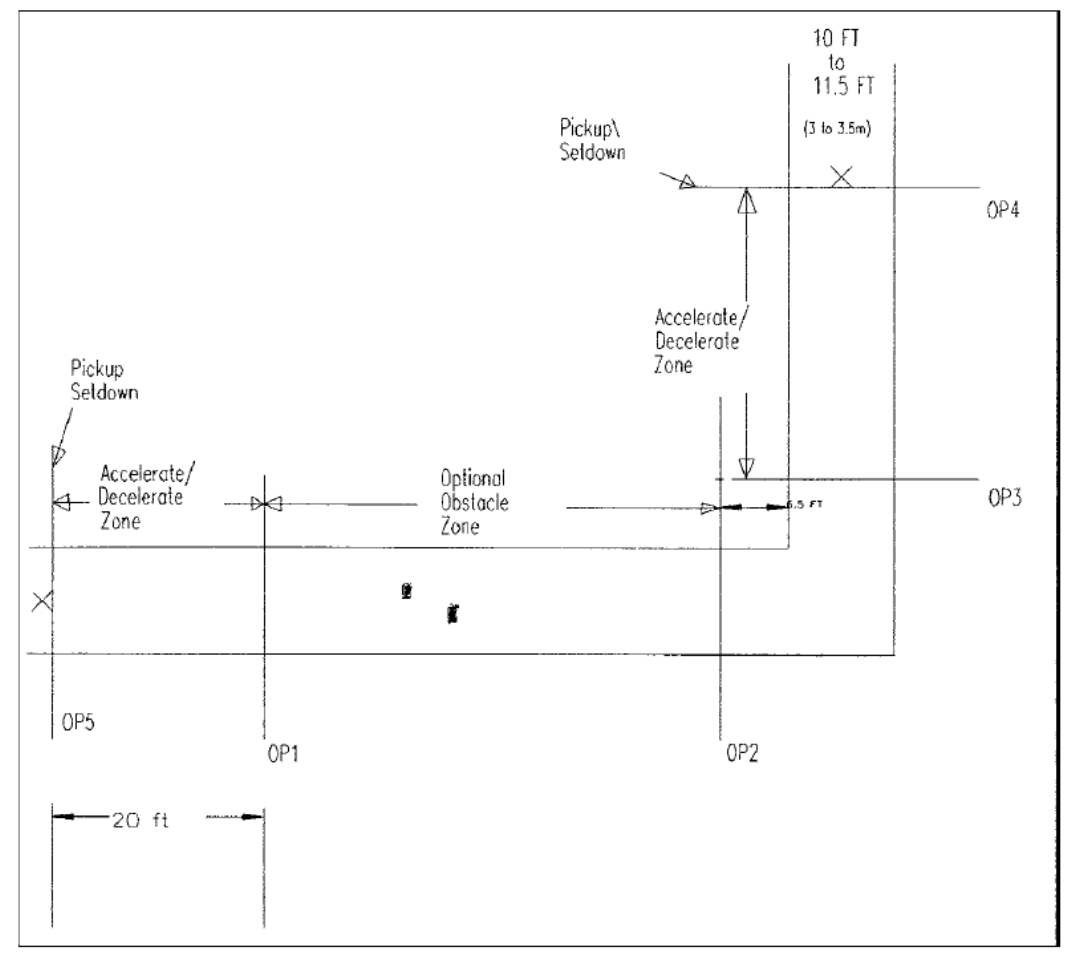

Figure 42: ASTM D6055 as Suggested

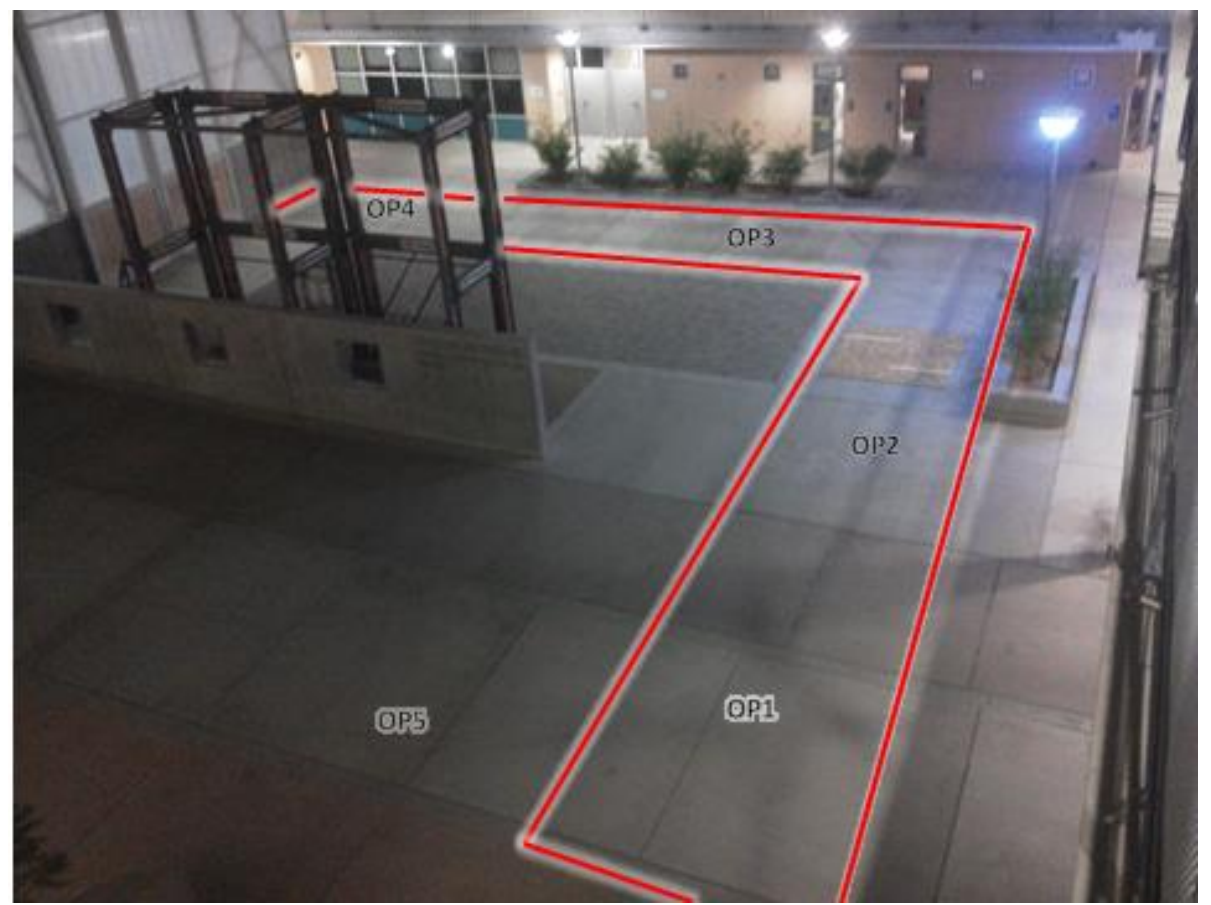

Figure 43: Handling Course as Performed

1. 


\subsubsection{ASTM Handling Procedure}

2. Position the lift truck with the unit load approximately 60 feet from the two wooden obstacles in Observation Point 1.

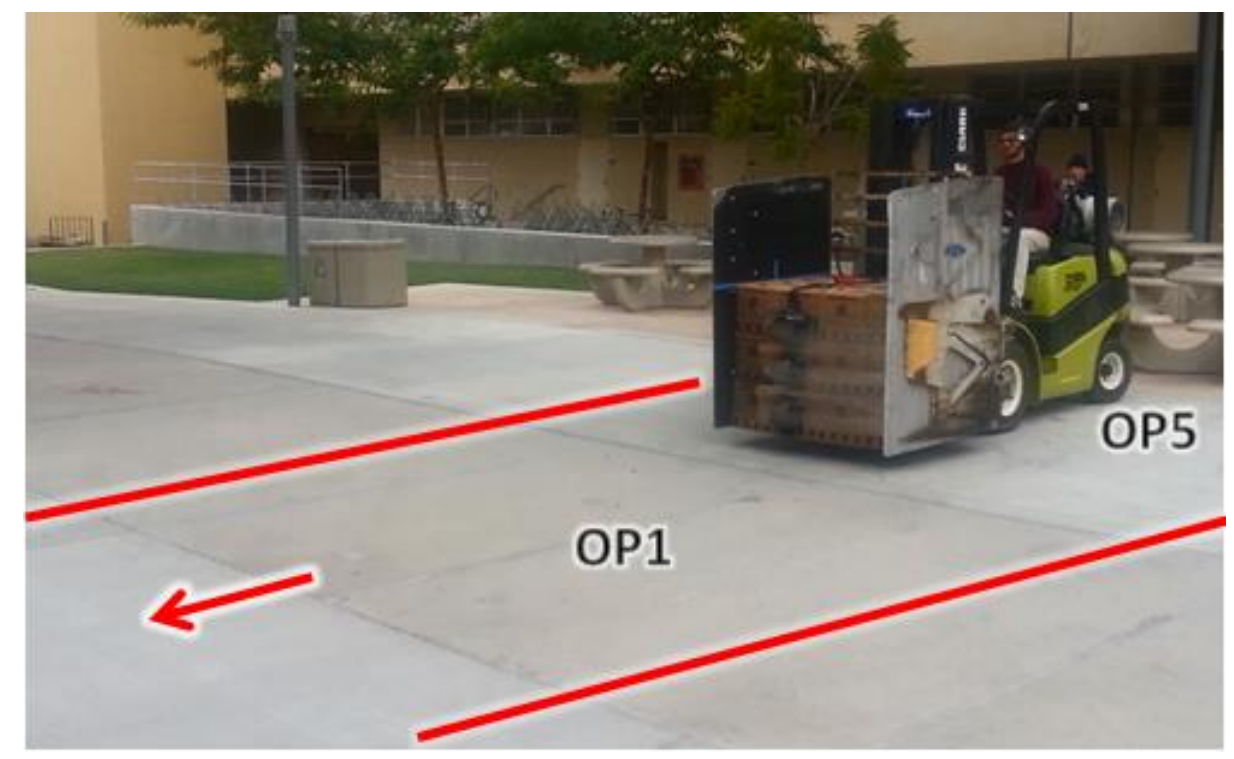

Figure 44: Pick-Up and Set-Down

3. Set the load down and pick up the load as flat off the ground as possible. The center of the load must be in line with the center of the compression pads.

4. Pick up the load to the appropriate load right height depending on the treatment needed as indicated in the test schedule.

5. Measure the unit load in the back, middle, and front in reference to the top of the driver side clamp pad. 
6. Using the one meter tape lines on the ground, establish a velocity of approximately $1 \mathrm{~m} / \mathrm{s}$.

7. Proceed over the plate obstacles while maintaining a safe velocity not to exceed 1 $\mathrm{m} / \mathrm{s}$.

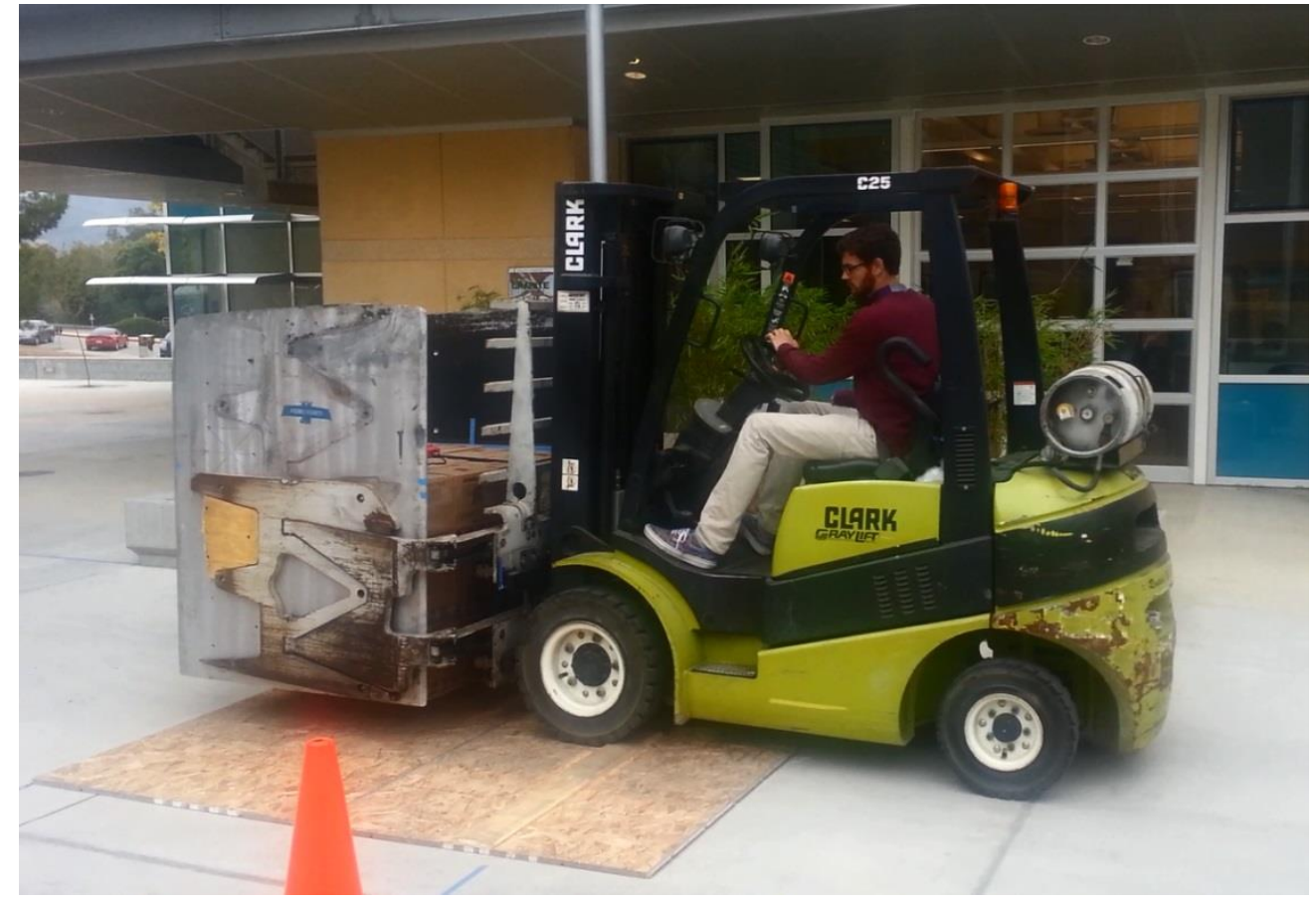

Figure 45: Progression over the Wooden Obstacles

8. After the lift truck passes the last wooden obstacle (Observation Point 2) turn 90 degrees to the left and accelerate back to approximately $1 \mathrm{~m} / \mathrm{s}$ then decelerate to a stop at Observation Point 4 


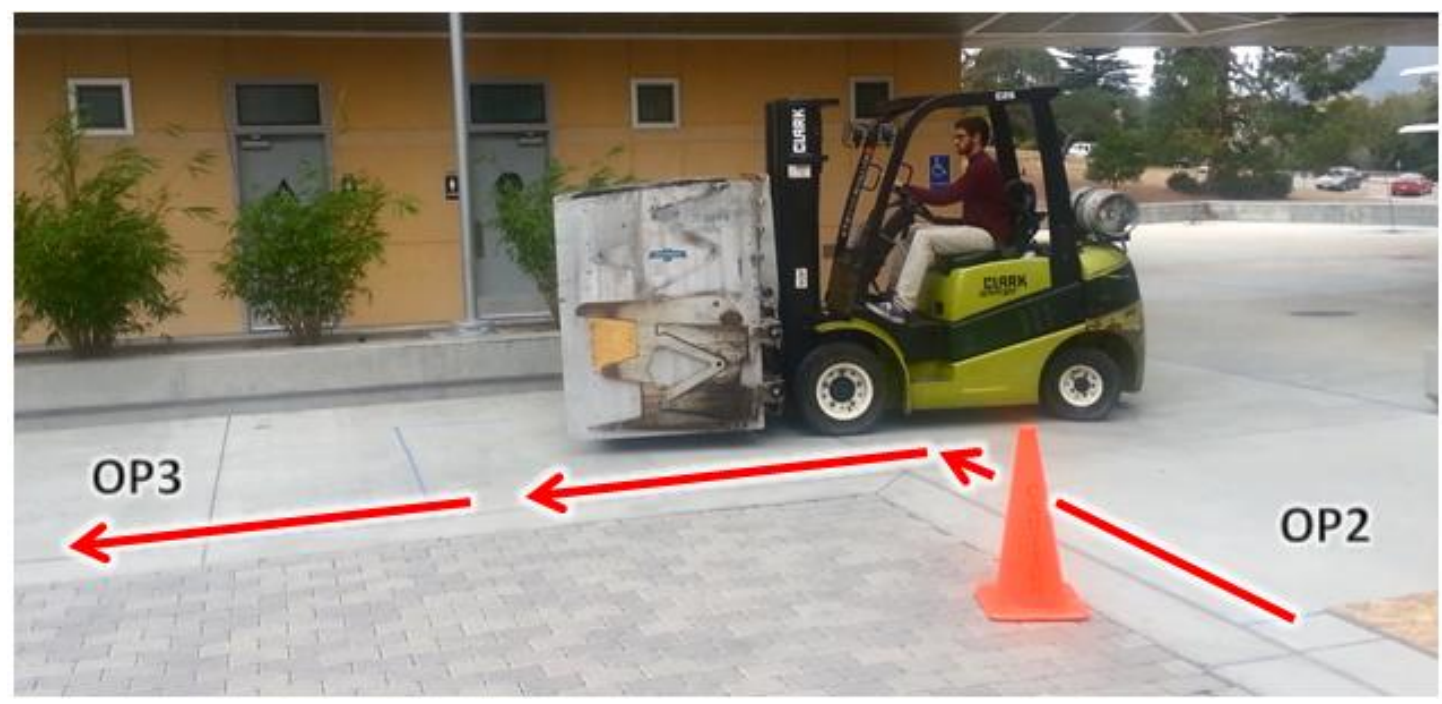

Figure 46: Left Turn after Wooden Obstacles

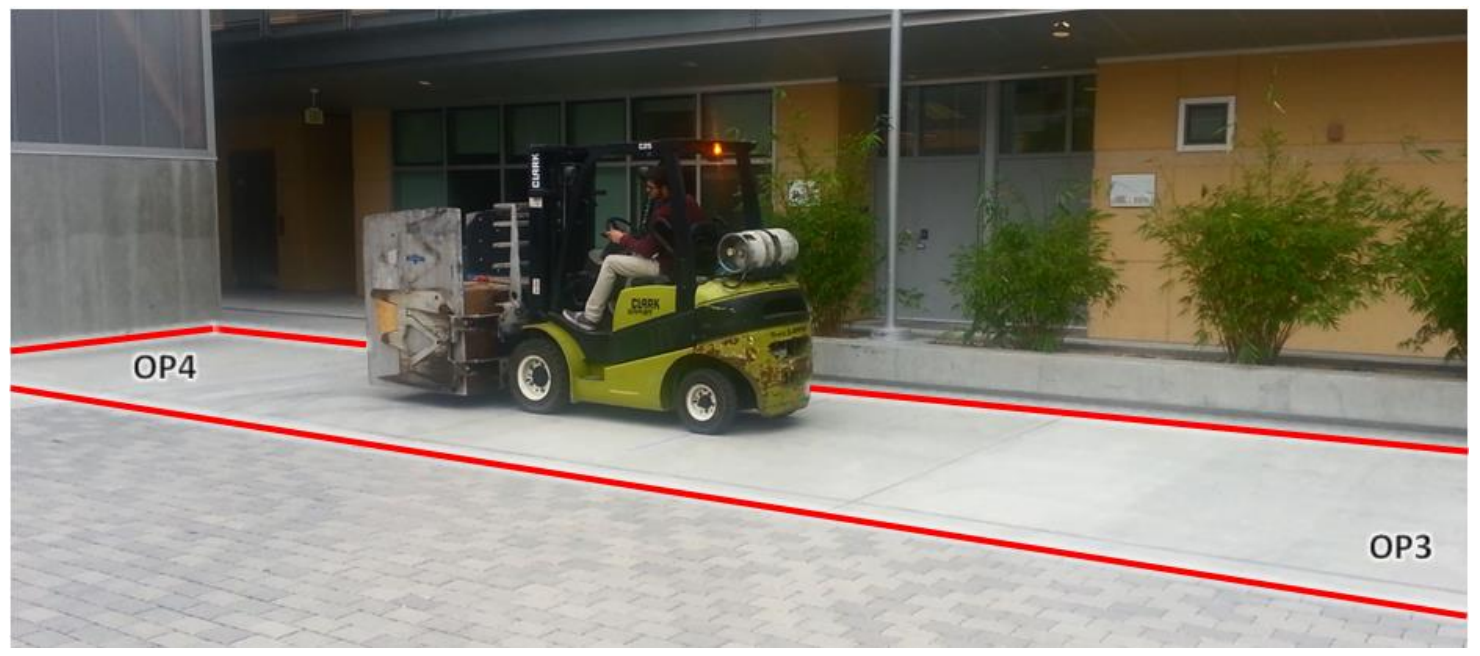

Figure 47: Pick-Up and Set-Down

9. Measure the unit load in the back, middle, and front in reference to the top of the driver side clamp pad. 
10. Set the load down and pick up the load as flat off the ground as possible. The center of the load must be in line with the center of the compression pads.

11. Set the load down and begin the stretch film relax time.

12. Record Relax Time on the data collection sheet.

\subsection{Post-Handling}

1. Once the 5 minute Relax Time has elapsed, pick up the unit load and return to the stretch wrapper.

2. Be diligent to follow the exact path back to the wrapper to eliminate unwanted variance in the handling.

3. Using a second operator, position the unit load in the geometric center of the turntable.

4. Set the unit load down onto the turntable.

5. Release the unit load from the carton clamp pads

6. Raise the carton clamp pads slightly above the stretch wrapper turn table.

7. Back up the lift truck.

8. Plug the load cell charger into a suitable 120VAC 15A outlet.

9. Cut the stretch film from the unitized load with the stretch film hook knife.

10. Record Cut Time on the data collection sheet.

\subsection{Stretch Film Laptop}

11. Stop Test, Create Graph and Save Data, save the text file and the graphic PDF to a specified folder. 


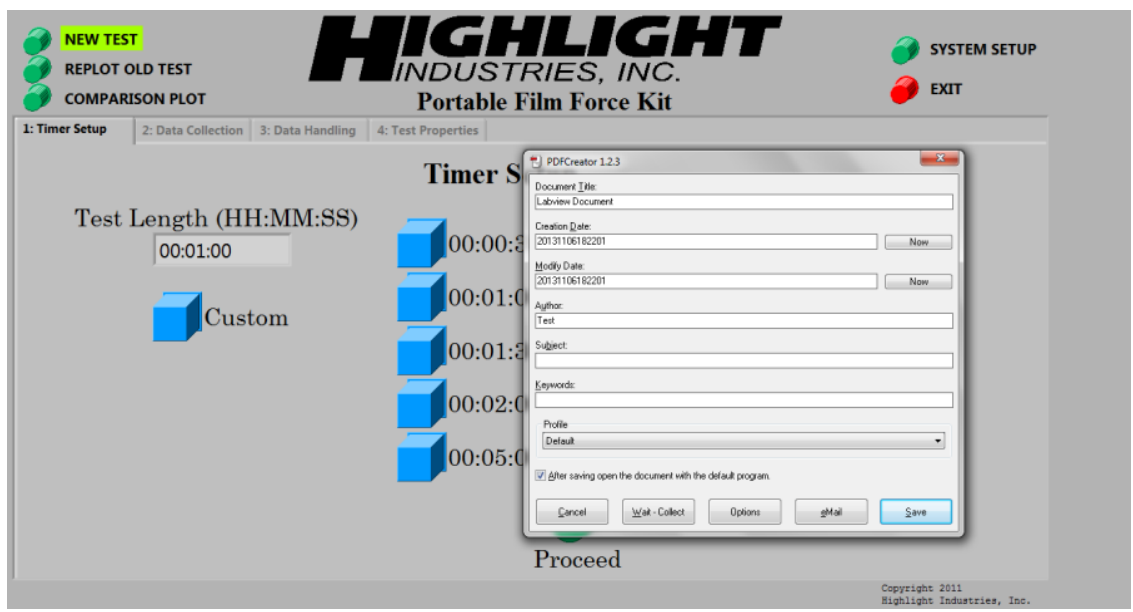

Figure 48: Exporting and Saving Data

12. Go to device set up and re-tare the load cells prior to each test

13. Proceed to Test

14. Select 1 hour for test duration.

15. Prepare the test for the next cycle. 


\subsection{Results and Discussion}

The generalized stages of the handling test cycle are shown in figure 49.

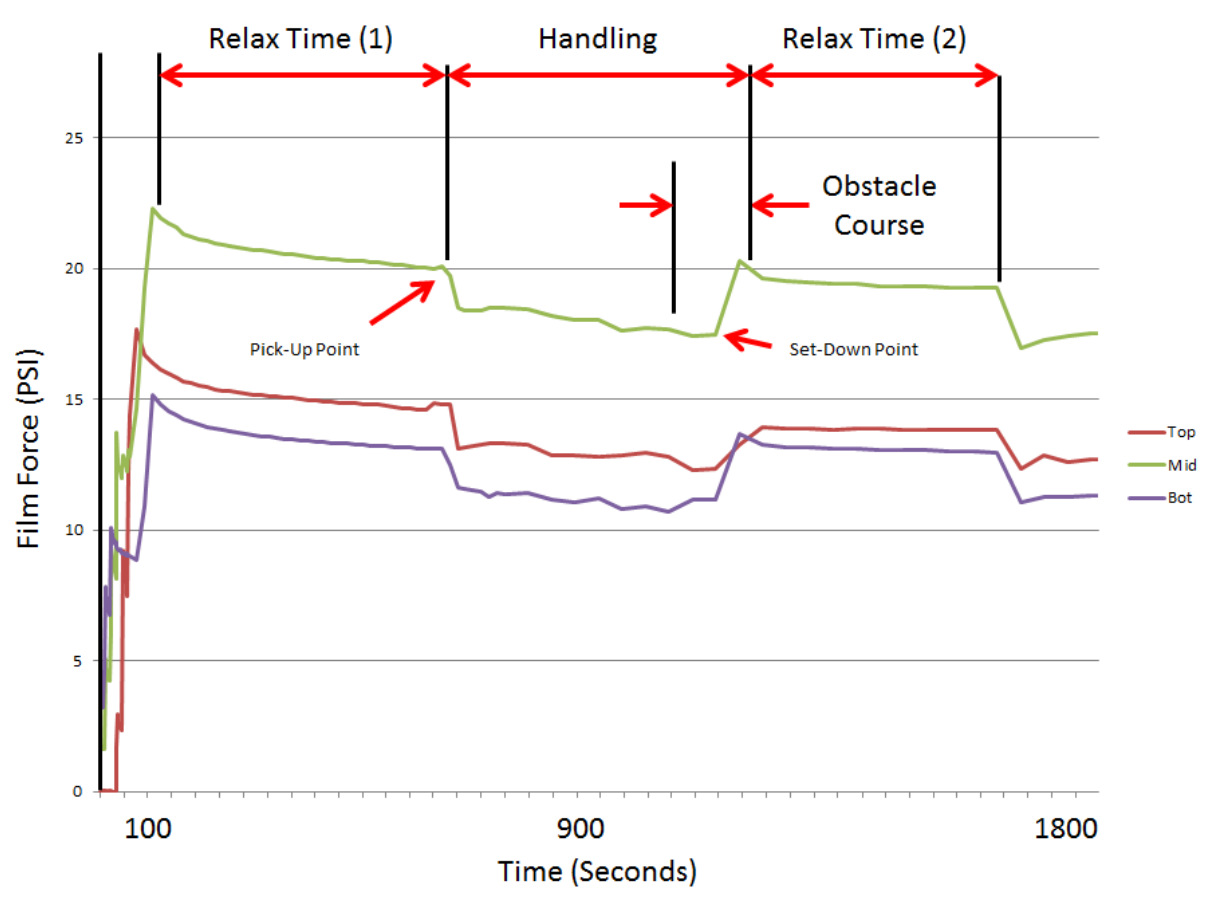

Figure 49: Handling Time Intervals

After the unit load is wrapped, the maximum film containment force degrades over time. As handling of the load begins, the film containment force fluctuates rapidly as the lift truck encounters unevenness in the road, changes in acceleration, and various environmental factors. As the lift truck traverses the multiple steel plate obstacles of ISTA 3B, or the two wooden obstacles of ASTM (with repeated pick-up and set-down procedure), the unit load experiences sharp spikes in acceleration causing more temporary fluctuation in the containment force. Once the handling course is complete, the clamping pressure is released and the film containment force recovers expediently. Once 
the stretch film recovers from the effects of the carton clamp, the film containment force again continues to degrade over time.

Figure: Detail view of the road hazards temporary effect on the film force

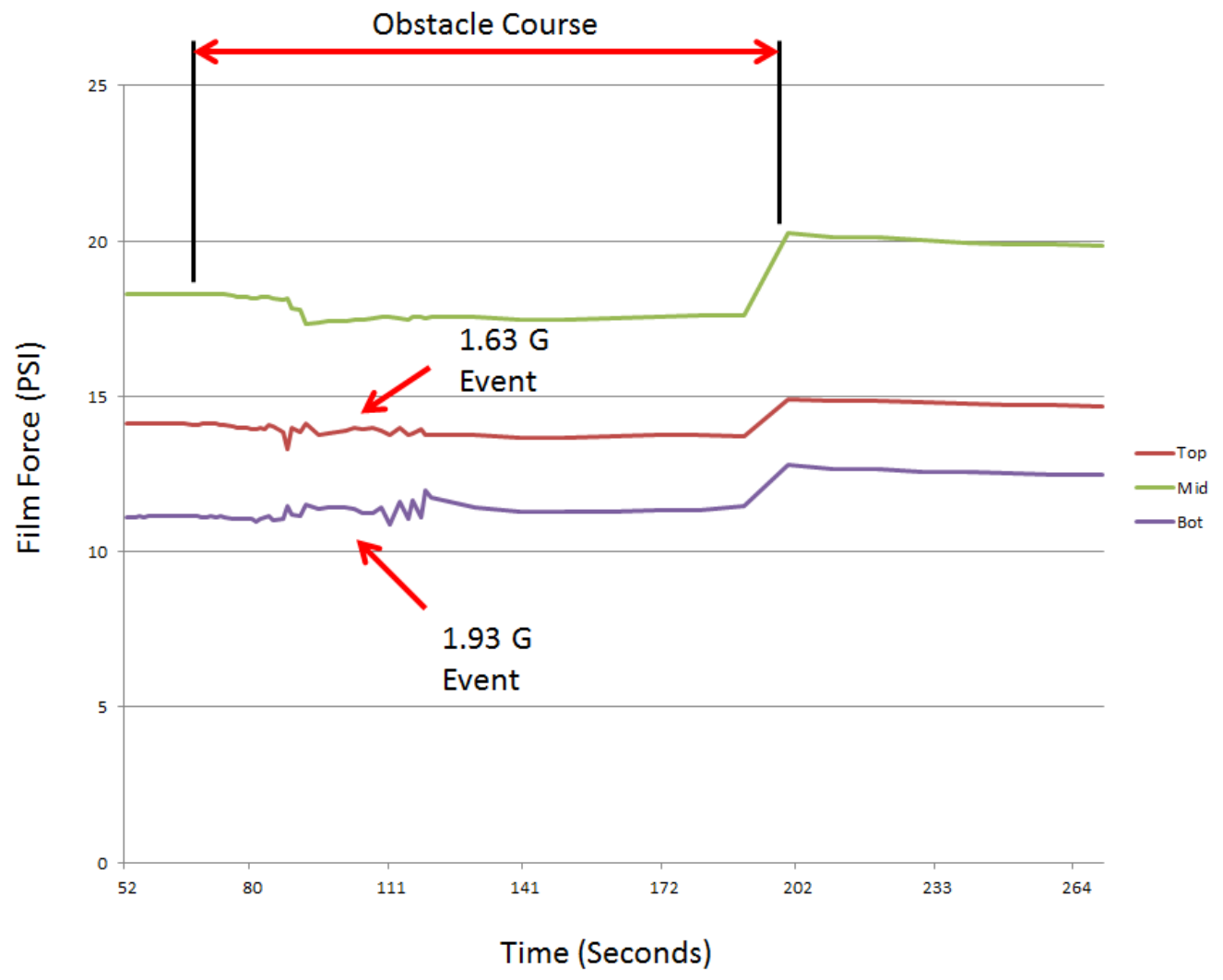

Figure 50: Detail View of Shock Events 
Table 10: Mean shock (SE) values for column stack pattern by factor.

\begin{tabular}{cc} 
Factors & Mean Shock \\
\hline Obstacle Course & \\
ASTM & $1.312(.165)$ \\
ISTA & $1.729(.165)$
\end{tabular}

Ride Height

.7214

Low $\quad 1.562(.165)$

High $\quad 1.478(.165)$

Recorder Location

.1757

Top $\quad 1.448(.202)$

Bottom $\quad 1.823(.202)$

Truck $\quad 1.289(.202)$

Driver (Random Effect)

Driver 1

Driver $2 \quad 1.305(.202)$

Driver $3 \quad 1.766(.202)$

$$
\begin{aligned}
& \mathbf{F}=1.6121 \\
& \text { P-value }=.1795
\end{aligned}
$$

Results: In regard to the mean shock values obtained by the data recorders, none of the factors were considered to be significant for the column stack pattern. The null hypothesis that the factors have no effect on the average acceleration of the shock event cannot be rejected. 
Table 11: Mean shock (SE) values for cross stack pattern by factor.

Factors

Obstacle Course

ASTM $2.022(.481)$

ISTA $\quad 1.279(.481)$

Ride Height

Low

High

Recorder Location

Top

$2.172(.589)$

Bottom

Truck
Mean Shock (G's) (SE) P-value

.2842

.1903

$1.194(.481)$

$2.106(.481)$

.1039

Driver (Random Effect)

.3231

Driver $1 \quad 2.388(.589)$

Driver $2 \quad 1.303(.589)$

Driver $3 \quad 1.262(.589)$

$$
\begin{aligned}
& \mathbf{F}=1.7065 \\
& \mathbf{P} \text {-value }=.1551
\end{aligned}
$$

Results: In regard to the mean shock values obtained by the data recorders, none of the factors were considered to be significant for the cross stack pattern. The null hypothesis that the factors have no effect on the average acceleration of the shock event cannot be rejected. 
Table 12: Quantity of shock events for column stack patterns by factor.

Factors

Obstacle Course

ASTM

ISTA

Ride Height

Low

High

Recorder Location

Top

$1.333(.371)$

Bottom

Truck

$2.250(.371)$

$0.833(.371)$ Mean Quantity of Shock Events (SE)

$\mathbf{8 9 7 7}$

$1.500(.303)$

$1.444(.303)$

.7001

$1.389(.303)$

$1.556(.303)$

.0356

Driver (Random Effect)

.4939

Driver 1

Driver $2 \quad 1.333(.371)$

Driver $3 \quad 1.833(.371)$

Results: When looking at the average quantity of shock events recorded above a $1.5 \mathrm{G}$ threshold, recorder location was found to be a significant factor ( $p$-value $<0.05)$ for the column stack pattern. The recorder on the bottom front of the unit load experienced almost twice as many shock events over $1.5 \mathrm{G}$ as the top recorder and nearly three times as many events as the truck recorder. 
Table 13: Quantity of shock events for cross stack pattern by factor.

Factors

Obstacle Course

ASTM

ISTA

\section{Mean Quantity of Shock Events (SE)}

.5751

$1.389(.346)$

$1.667(.346)$

Ride Height

Recorder Location

Driver (Random Effect)

Low

$1.056(.346)$

High

$2.000(.346)$

Top

$1.250(.424)$

Bottom

$2.667(.424)$

Truck

$0.667(.424)$

.0637

.0072

Driver $1 \quad 1.083(.424)$

Driver $2.583(.424)$

Driver $3 \quad 0.917(.424)$
.0173

$$
\begin{aligned}
& \mathbf{F}=4.1925 \\
& \mathbf{P} \text {-value }=0.0037
\end{aligned}
$$

Results: When looking at the average quantity of shock events recorded above a $1.5 \mathrm{G}$ threshold, driver and recorder location were found to be significant factors p-value $<0.05)$ for the cross stack pattern. It is worth noting that ride height was nearly significant. In regard to recorder location, the recorder on the bottom experienced more than twice the shock events of the recorder on the top and approximately four times as 
many events as that mounted to the truck. Driver is a random effect variable and cannot be correlated to any definitive study, but driver 2 induced more than twice the shock events of driver 1 and nearly 3 times as many events as driver 3 . The high ride height condition performed at 12 inches off the ground induced approximately twice as many shock events as the low ride height performed 6 inches off the ground. Due to the P-value over .05 , it cannot be proven that these events were not recorded by chance.

Table 14: Slippage for column stack pattern by factor.

ASTM

$0.174(.080)$

ISTA

\section{Ride Height}

.6697

Low

$.219(.080)$

High

$.170(.080)$

Sector

.0003

Front $\quad .026(.098)$

Middle $\quad .042(.098)$

Back $\quad .568(.098)$

Driver (Random Effect)

Driver 1

$.245(.098)$

Driver 2

$.245(.098)$

Driver 3

$.078(.098)$

$\mathbf{F}=4.1004$

$$
\text { P-value }=.0042
$$


Results: For the column stack pattern, sector is the only significant factor. The unitized load slips considerably more in the back (closest to the driver) than in the middle or front of the load. The middle indicates more slippage than the front of the load.

Table 15: Slippage for cross stack pattern by factor.

Factors

Obstacle Course

ASTM

ISTA
Mean Slippage Delta (in.) (SE)

P-value

0.1276

$.010(.049)$

$.120(.049)$

Ride Height

Low

$.019(.049)$

High

$.111(.049)$

Sector

Front

$.011(.060)$

Middle

$.013(.060)$

Back

0.1962

Driver (Random Effect)

Driver 1

$.073(.060)$

Driver 2

.073 (.060)

Driver 3

$.003(.060)$

.0471

.3954

$$
\mathbf{F}=2.1550
$$

P-value $=.0770$

Results: For the cross stack pattern, sector is the only significant factor. The unitized load slips considerably more in the back (closest to the driver) than in the middle or front of the load. The middle indicates slightly more slippage than the front of the load. 
Table 16: Stretch film containment force on column stack pattern by factor.

Factors Mean Film Containment Force (SE) P-value

Obstacle Course

$\mathbf{0 . 6 4 2 6}$

ASTM $\quad 16.816(0.109)$

ISTA $\quad 16.744(0.109)$

Ride Height

0.1227

Low $\quad 16.899(0.109)$

High $\quad 16.661(0.109)$

Handling

$<.0001$

Before $\quad 17.663(0.109)$

After $\quad 15.897(0.109)$

Load Cell Position

$<.0001$

Top $\quad 17.014(0.134)$

Middle $\quad 22.145(0.134)$

Bottom $\quad 11.182(0.134)$

Time (Parameter Estimate) $-0.004172(.001) \quad<.0001$

Driver (Random Effect) $\quad<.0001$

Driver $17.091(0.134)$

Driver $215.993(0.134)$

Driver $317.091(0.134)$

$$
\begin{aligned}
& \mathbf{F}=448.654 \\
& \mathbf{P} \text {-value }=<.0001
\end{aligned}
$$


Results: For the column stack pattern, handling, load cell position, time and driver are all significant factors affecting film containment force ( $\mathrm{p}$-value $<0.05$ ). Handling the unit load, that is clamping the load, moving the load to an obstacle course, traversing the course, and unclamping the load has a significant effect on the containment film force. The data however, shows no significant difference in the effects of the two obstacle course methodologies or in the two ride heights at which the tests performed. Time has a constant effect on the film containment force, reducing at a rate of .004 PSI per second. Load cell position also effects film force; however the starting containment force is highly dependent on the wrap pattern selected for testing. 
Table 17: Stretch film containment force on cross stack pattern by factor.

Factors

Obstacle Course

ASTM $\quad 16.778(0.091)$

ISTA $\quad 16.998(0.095)$

Ride Height

Low

High

Handling

Before

After

Load Cell Position

Top

$14.254(0.114)$

Middle

$21.024(0.114)$

Bottom

$15.386(0.114)$

$16.886(0.091)$

$16.889(.095)$

$17.842(0.095)$

$15.934(0.091)$
0.9837

$<.0001$

$<.0001$

$<.0001$

$<.0699$
Driver 1

Driver 2

Driver 3
$16.780(0.120)$

$16.784(0.111)$

$17.100(0.111)$

$$
\begin{aligned}
& \mathbf{F}=289.4598 \\
& \mathbf{P} \text {-value }=<.0001
\end{aligned}
$$


Results: For the cross stack pattern, handling, load cell position, and time are all significant factors affecting film containment force ( $\mathrm{p}$-value $<0.05$ ). Handling the unit load, that is clamping the load, moving the load to an obstacle course, traversing the course, and unclamping the load has a significant effect on the containment film force. The data however, shows no significant difference in the effects of the two obstacle course methodologies or in the two ride heights at which the tests performed. Time has a constant effect on the film containment force, reducing at a rate of .004 PSI per. The data shows no significant difference in the effects of the two obstacle course methodologies. The driver random effect variable is insignificant in this scenario ( $p$-value $>0.05$ ). 


\subsection{Conclusion}

When examining the average acceleration of shock events for the cross and column stacked unit loads, no evidence was found to support a relationship between the average intensity of the event and the obstacle course, ride height, data recorder position, or driver. There is evidence however of a relationship between the quantities of shock events sustained and position of the data recorder. The data recorder position towards the bottom of the unit load sustained significantly more shock events than the recorder positioned at the top of the unit load. This relationship was found to be significant for both the cross and column stack patterns.

After looking at the column and cross stack loads' tendencies to slip between the clamp pads during transit, there is no evidence of a relationship between the amount of slippage and the obstacle course, ride height, or driver. Only the sector factor: back, middle, or front of the load was found to be significant. The back most cases, closest to the driver are the most prone to slippage during handling, followed by the front most cases and finally the middle most cases.

The study has found that in regard to film force the natural decay of film force over time, load cell position and handling of the unit load by clamp truck have the most noteworthy effect on film containment force for both the column stack and cross stack patterns. The film force sustained no distinguishable difference between the ASTM 6055 handling course and the modified ISTA 3B-2013 handling course. 


\subsection{Significance of Results}

- When using a carton clamp attachment, cases towards the bottom of the load experience more shock events than those at the top.

- Cases towards the back of the unitized load, closest to the operator are more likely to slip than those in the front or middle of the clamp pads during repeated shock events.

- While effected by time, clamp truck handling, and presence of road hazards in general; in this study, film containment force was not found to be affected by the differences in the quantity or material of the hazards.

- In this study, ride height was not found to be a significant factor for shock, containment, or retention between the heights of six and twelve inches.

\subsection{Suggested Future Research}

There is evidence presented in this experiment that cases at the front-bottom of the unit load experience more shock events than cases at the front-top. A follow up study could be conducted to determine exactly how shock events are transmissible through a carton clamped load. Column stack and cross stack unitized loads should be built with data recorders at each corner and geometric middle of the load. Dummy weight should be used to simulate a realistic unit load weight. This will allow patterns of shock transmissibility to be determined for each stack pattern.

The study could be repeated with a different type of product, an agricultural product such as produce may behave entirely differently as it is light weight and has substantially more give than a case of rigid glass bottles. 
As there is no significant difference between the two obstacle courses, a study should be conducted to determine if the ISTA-3B handling course can be constructed of lumber instead of cold rolled steel. This will allow more operators and practitioners the ability to construct the handling course without the cost preventative processing required for fabricating steel plate obstacles.

To achieve a more thorough understanding of how each individual carton moves or shift during clamp truck handling, string potentiometers could be implemented to measure individual case displacement. The string potentiometers could be fastened to a fixed datum point on the clamp pad and run to a fixture in each case. As the cartons shift and slip between the clamp pads, the string potentiometer would change length and send a corresponding electrical signal to a data recorder. The electrical signal (change in voltage or current) could then be plotted over time. This would allow better resolution as to how individual plate obstacles or obstacle courses affect slippage. 


\section{Bibliography}

1. ATSM "D 6055-2007 Standard Test Methods for Mechanical Handling of Unitized Loads and Large Shipping Cases and Crates" American Society for Testing and Materials (2007): 1-5. Print

2. ASTM "D 4649: Selection and Use of Stretch Wrap Films." American Society for Testing and Materials 03 (2009): 1-11. Print

3. ISTA "3B-2013: Packaged-Products for Less-Than-Truckload LTL Shipment” International Safe Transit Association (2013): 11, 32. Print.

4. ISTA “6 SAMSCLUB-2010: Packaged-Products for Sam's Club® Distribution System Shipment" International Safe Transit Association (2010): 20, 39. Print.

5. Avery, Fred J. Clamp for Lift Trucks. Avery, Fred J, assignee. Patent US2475367A. 5 July 1949. Print.

6. Cascade Corp. "History." Cascade Corporation. N.p., 2013. Web. 10 Nov. 2013.

7. Cernokus, Evan A. "The Effect of Stretch Wrap Pre-Stretch on Unitized Load Containment." Thesis. California Polytechnic State University San Luis Obispo, 2012. Print.

8. Chen, Zhangjing, Marshall White, and Yiqiang Wu. "Vacuum-Steam Phytosanitation of Hardwood Pallets and Pallet Stringers." Forest Products Journal 62.5 (2012): 378-79. ProQuest International Academic Research Library. Web. 7 Nov. 2013.

9. Ehmann, Leslie G. Load Gripping Means for Lift Trucks. Hyster Co, assignee. Patent US2681162 A. 15 June 1954. Print.

10. Ehmann, Leslie G. Material Handling Equipment for Industrial Trucks. Hyster Co, assignee. Patent US2571550. 16 Oct. 1951. Print.

11. Ehmann, Leslie G. Material Handling Equipment for Industrial Trucks. Hyster Co, assignee. Patent US2706061 A. 12 Apr. 1955. Print.

12. Guadagnini, David, Jay Singh, Dr., Koushik Saha, Dr., and Paul Singh, Dr. "Shock Transmissibility of a Palletized Load Caused by Forklift Truck Handling." Proc. of Eighteenth IAPRI World Packaging Conference, California Polytechnic State University, San Luis Obispo. Lancaster: DEstech, 2012. 432-34. Print.

13. Molina-Murillo, Sergio A., Timothy M. Smith, Mike Reichenbach, and Robert Smith. "Impact of International Phytosanitary Standards on Wood Packaging Material End Users: Pre-implementation Assessment." Forest Products Journal 55.9 (2005): 24-25. Proquest. Web. 26 Oct. 2013.

14. "National Wooden Pallet and Container Association: Environment for Sale." National Wooden Pallet and Container Association Newsletter (25 Nov. 2008): 1-3. ProQuest Agriculture Journals. Web. 13 Nov. 2013. 
15. Schafer, Elise. "Automation and Contamination Concerns Drive Pallet Purchasing Decisions." Food Logistics (Apr.-May 2010): 39-41. ProQuest 5000. Web. 13 Nov. 2013.

16. Spencer, David K., and C.W. Ebeling. "Push/Pull \& Slipsheet Handling Manual." Global Solutions in Materials Handling (Apr.-May 2011): 10-14, 47-48. Print.

17. Stewart, James, and Greg Batt. Clamp Truck Simulation in the Laboratory Enviroment. Thesis. Clemson University, 2005. N.p.: n.p., n.d. Print.

18. Suhy, Andrew, and Chad Trucktor. Lift Truck Clamp Test System. Total Fleet Solutions, assignee. Patent US8201463 B1. 19 June 2012. Print

19. USA. U.S. Department of Labor. Occupational Safety and Health Administration. Powered Industrial Trucks (Forklift). Occupational Safety and Health Administration, n.d. Web. 5 Nov. 2013. <https://www.osha.gov/SLTC/etools/pit/operations/loadcomposition.html>. 


\section{Appendices}

\section{Appendix A: Obstacle as Built Drawings}

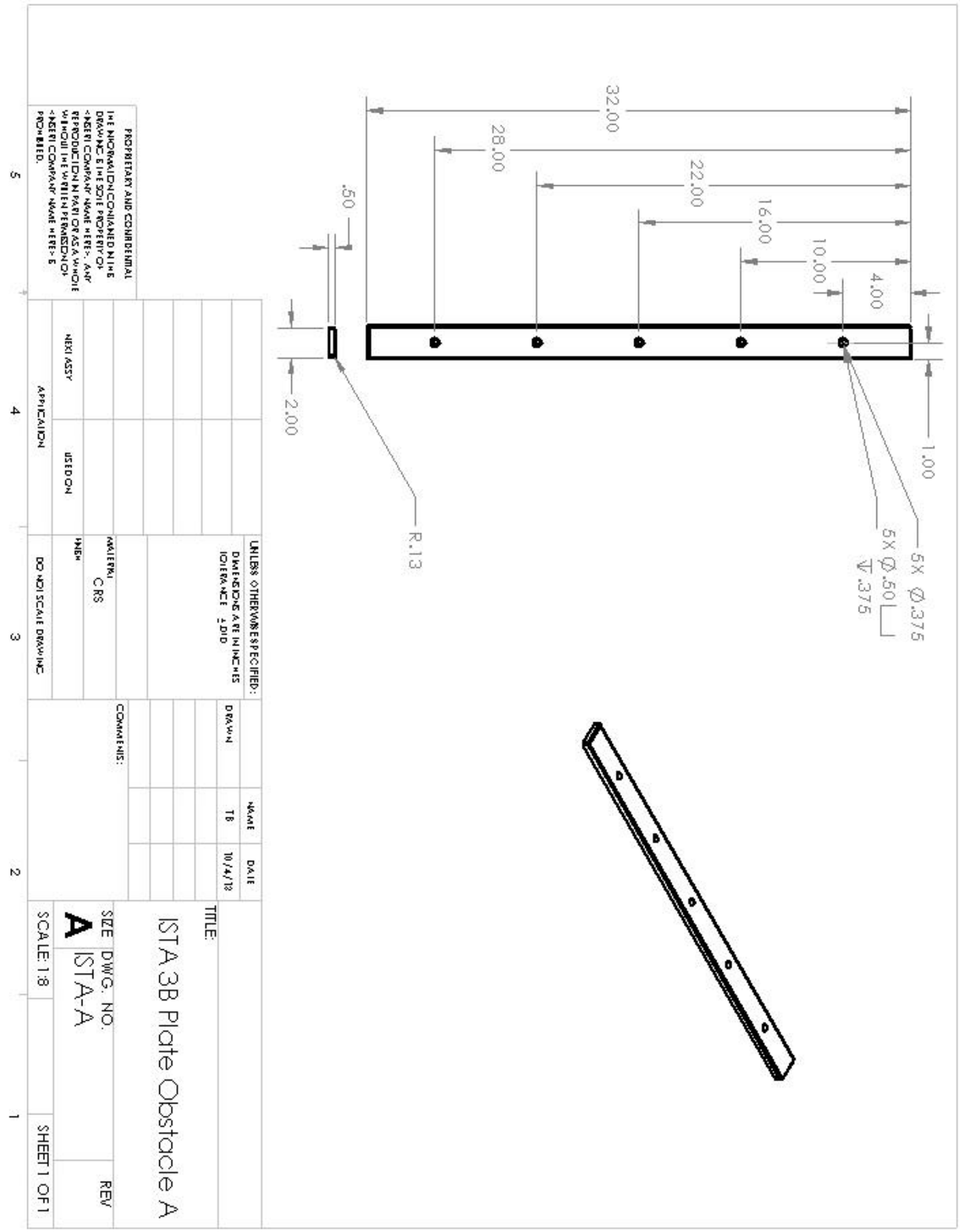


ISTA-3B Plate Obstacle B

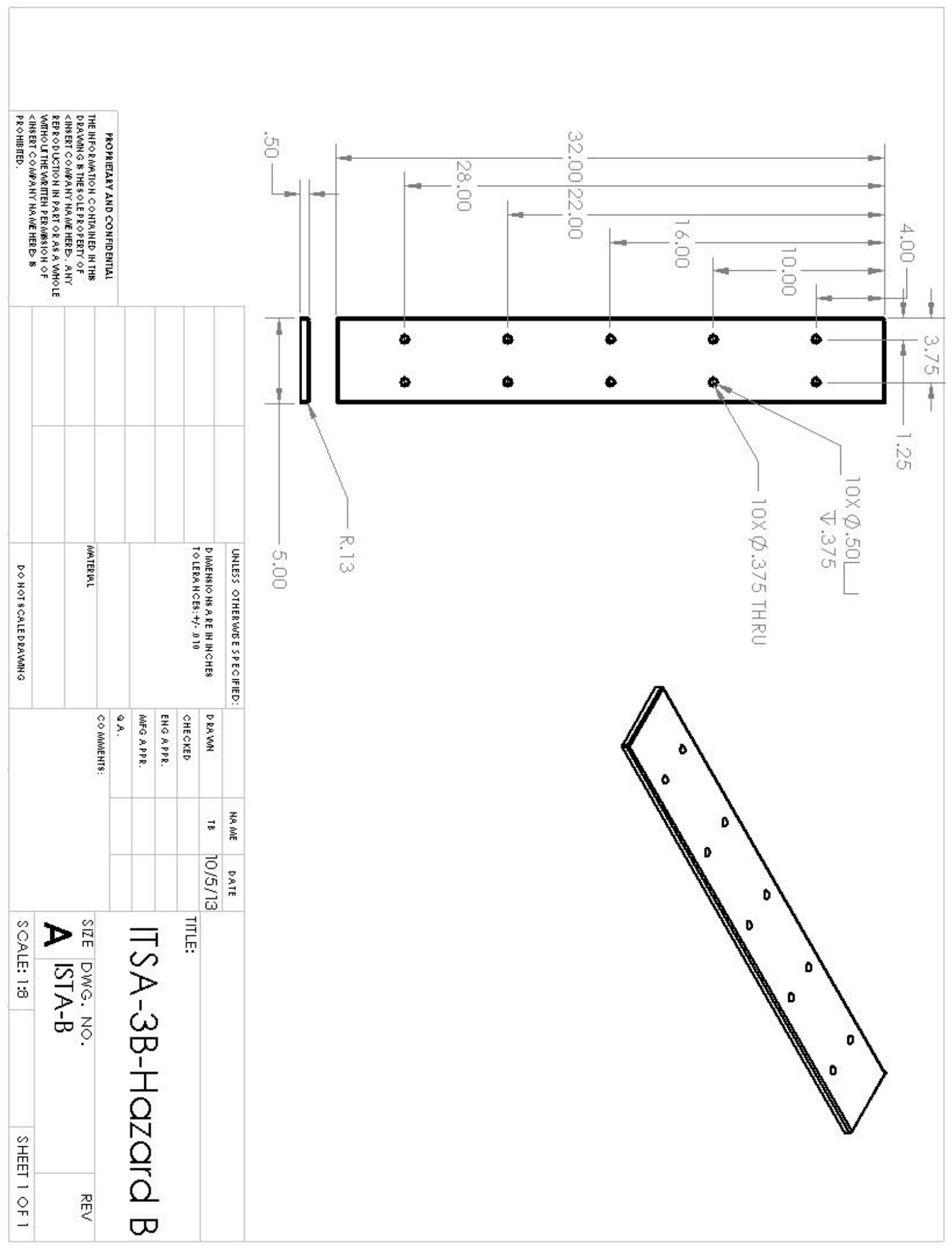


ISTA-3B Plate Obstacle C

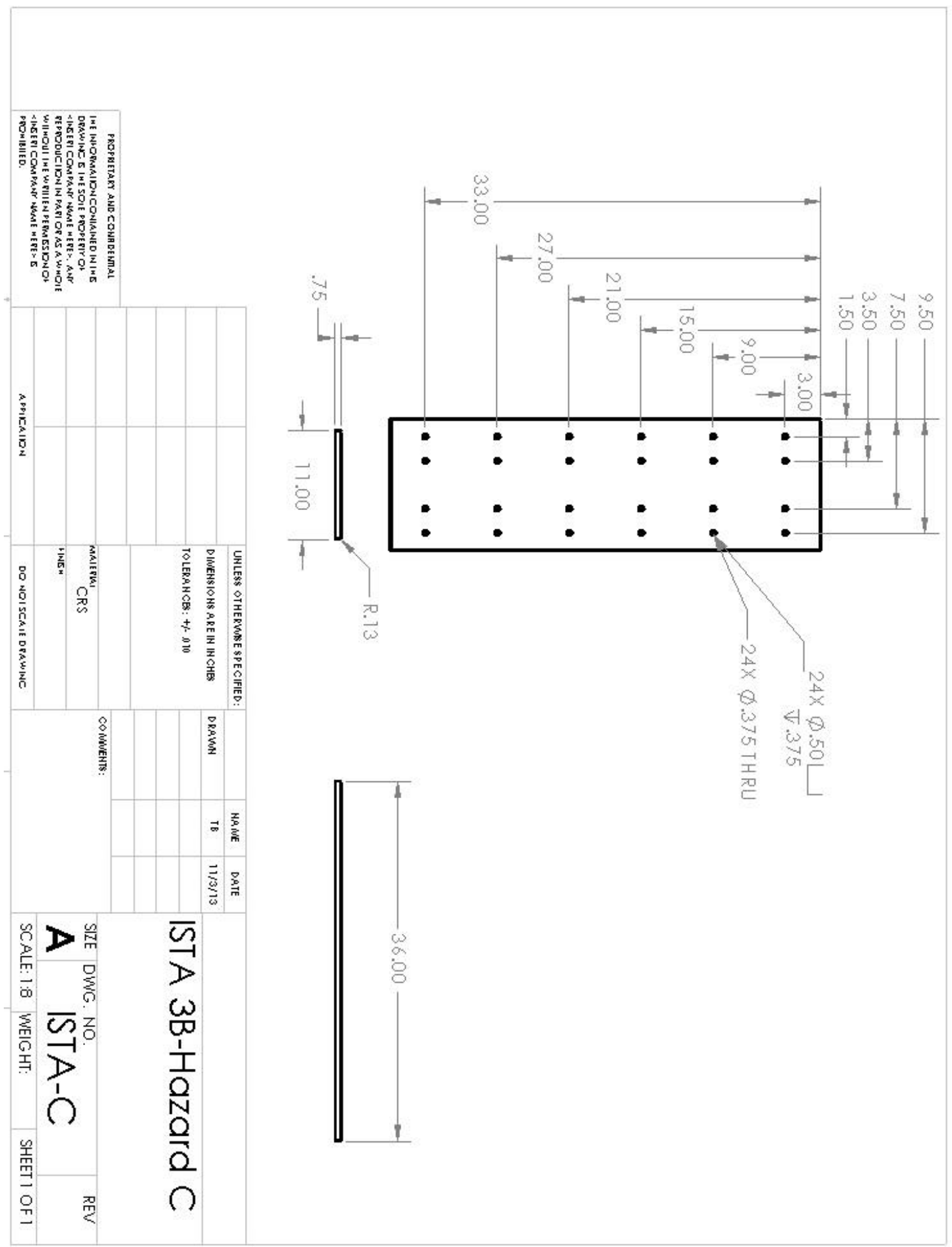




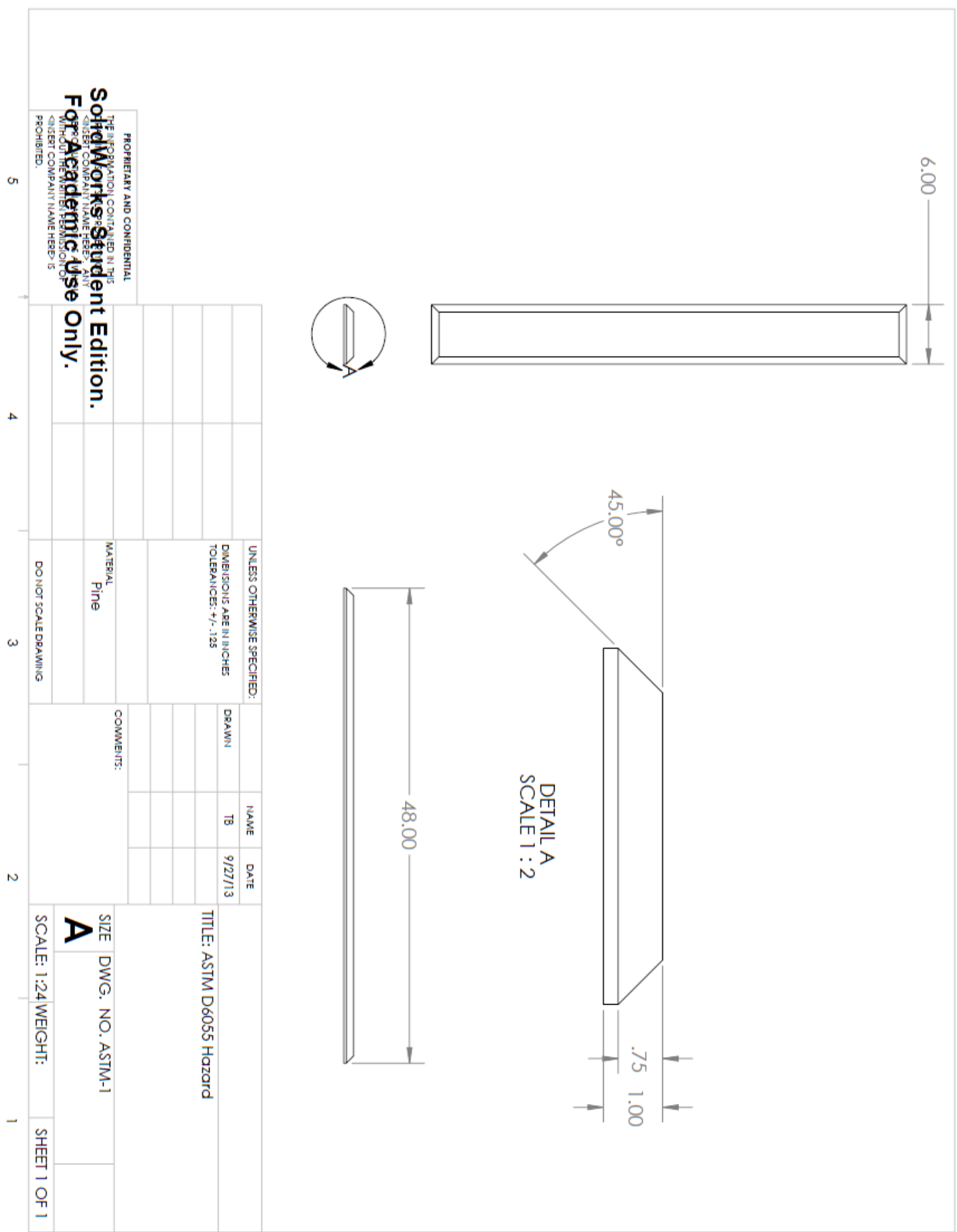




\section{Appendix B: Statistical Output Data for Scenarios}

\section{Average Acceleration of Shock Event Column Stack}

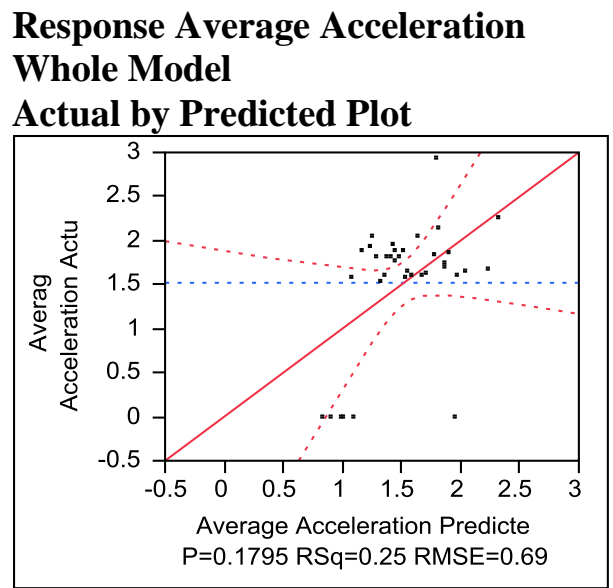

\section{Summary of Fit}

RSquare

RSquare Adj

Root Mean Square Error

Mean of Response

Observations (or Sum Wgts)
0.250114

0.094965

0.69899

1.520278

36

\section{Analysis of Variance}

Source DF

Model

Error

C. Total

6

29

35

\section{Parameter Estimates}

Term

Intercept

Obstacle Course[ASTM]

Ride Height[Low]

Recorder Location[Bottom]

Recorder Location[Top]

Driver[Justin]

Driver[Kainoa]

$\begin{array}{rrr}\begin{array}{r}\text { Sum of } \\ \text { Squares }\end{array} & \text { Mean Square } & \text { F Ratio } \\ 4.725883 & 0.787647 & 1.6121 \\ 14.169014 & 0.488587 & \text { Prob }>\text { F } \\ 18.894897 & & 0.1795\end{array}$

$\begin{array}{rrrr}\text { Estimate } & \text { Std Error } & \text { t Ratio } & \text { Prob }>|\mathbf{t}| \\ 1.5202778 & 0.116498 & 13.05 & <.0001^{*} \\ -0.208611 & 0.116498 & -1.79 & 0.0838 \\ 0.0419444 & 0.116498 & 0.36 & 0.7214 \\ 0.3030556 & 0.164753 & 1.84 & 0.0761 \\ -0.071944 & 0.164753 & -0.44 & 0.6656 \\ 0.2455556 & 0.164753 & 1.49 & 0.1469 \\ -0.030278 & 0.164753 & -0.18 & 0.8555\end{array}$




\section{Expected Mean Squares}

The Mean Square per row by the Variance Component per column

\begin{tabular}{|c|c|c|c|c|c|}
\hline EMS & Intercept & $\begin{array}{r}\text { Obstacle } \\
\text { Course }\end{array}$ & Ride Height & $\begin{array}{l}\text { Recorder } \\
\text { Location }\end{array}$ & $\begin{array}{r}\text { Driver\&Rando } \\
\text { m }\end{array}$ \\
\hline Intercept & 0 & 0 & 0 & 0 & 0 \\
\hline Obstacle & 0 & 18 & 0 & 0 & 0 \\
\hline Course & & & & & \\
\hline Ride Height & 0 & 0 & 18 & 0 & 0 \\
\hline Recorder & 0 & 0 & 0 & 12 & 0 \\
\hline Location & & & & & \\
\hline Driver\&Rando & 0 & 0 & 0 & 0 & 12 \\
\hline
\end{tabular}

plus 1.0 times Residual Error Variance

$\begin{array}{lrr}\begin{array}{l}\text { Variance Component Estimates } \\ \text { Component }\end{array} & \begin{array}{r}\text { Var Comp } \\ \text { Est }\end{array} & \begin{array}{r}\text { Percent of } \\ \text { Total }\end{array} \\ \text { Driver\&Random } & 0.013064 & 2.604 \\ \text { Residual } & 0.488587 & 97.396 \\ \text { Total } & 0.501651 & 100.000\end{array}$

These estimates based on equating Mean Squares to Expected Value.

Test Denominator Synthesis

Source

Obstacle Course

Ride Height

Recorder Location

Driver\&Random
MS Den

0.48859

0.48859

0.48859

0.48859
DF Den Denom MS

Synthesis

29 Residual

29 Residual

29 Residual

29 Residual

Tests wrt Random Effects

$\begin{array}{lrrrrr}\text { Source } & \text { SS } & \text { MS Num } & \text { DF Num } & \text { F Ratio } & \text { Prob > F } \\ \text { Obstacle Course } & 1.56667 & 1.56667 & 1 & 3.2065 & 0.0838 \\ \text { Ride Height } & 0.06334 & 0.06334 & 1 & 0.1296 & 0.7214 \\ \text { Recorder Location } & 1.80517 & 0.90259 & 2 & 1.8473 & 0.1757 \\ \text { Driver\&Random } & 1.29071 & 0.64535 & 2 & 1.3209 & 0.2825\end{array}$


Residual by Predicted Plot

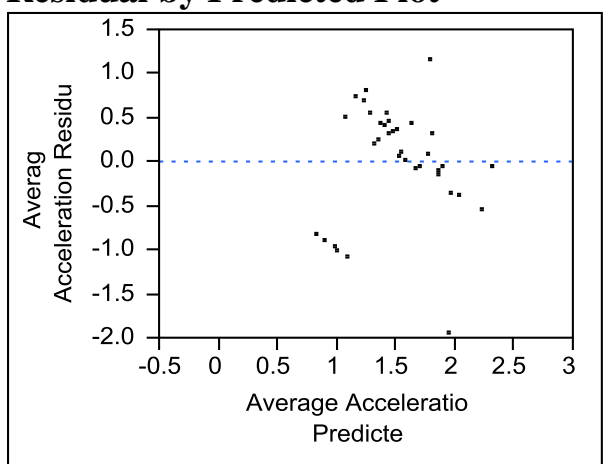

Obstacle Course

Leverage Plot

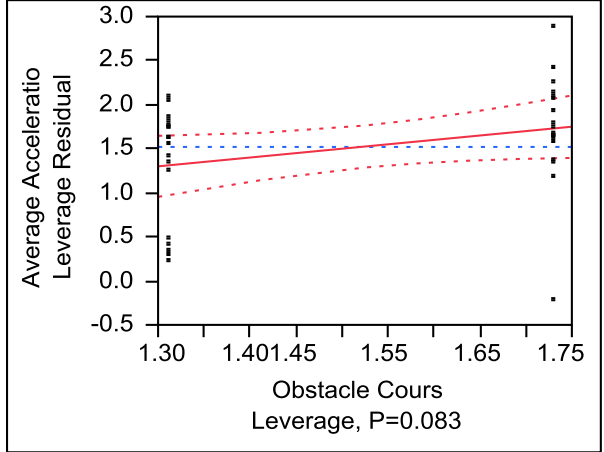

\section{Effect Test}

Sum of F Ratio DF Prob $>$ F

Squares

$\begin{array}{llll}1.5666694 & 3.2065 & 1 & 0.0838\end{array}$

Denominator MS Synthesis:

Residual

Least Squares Means Table

Level Least Sq Std Error Mean

Mean

$\begin{array}{llll}\text { ASTM } & 1.3116667 & 0.16475347 & 1.31167\end{array}$

$\begin{array}{llll}\text { ISTA } & 1.7288889 & 0.16475347 & 1.72889\end{array}$ 
Ride Height

Leverage Plot

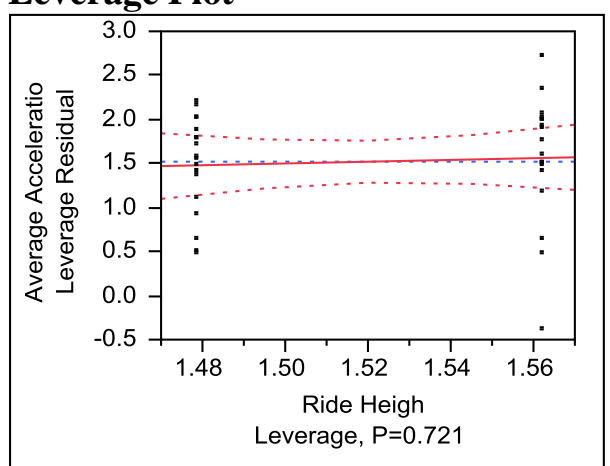

\section{Effect Test}

$\begin{array}{rrcr}\begin{array}{r}\text { Sum of } \\ \text { Squares }\end{array} & \text { F Ratio } & \text { DF } & \text { Prob }>\text { F } \\ 0.1296 & 1 & 0.7214\end{array}$

Denominator MS Synthesis:

Residual

$\begin{array}{lrrr}\begin{array}{l}\text { Least Squares Means Table } \\ \text { Level }\end{array} & \begin{array}{r}\text { Least Sq } \\ \text { Mean }\end{array} & \text { Std Error } & \text { Mean } \\ \text { Low } & 1.5622222 & 0.16475347 & 1.56222 \\ \text { High } & 1.4783333 & 0.16475347 & 1.47833\end{array}$

Recorder Location

Leverage Plot

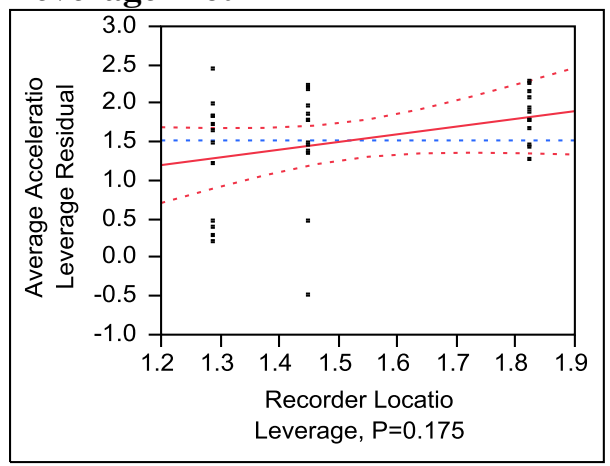




$\begin{array}{rrrr}\text { Effect Test } & & & \\ \begin{array}{c}\text { Sum of } \\ \text { Squares }\end{array} & \text { F Ratio } & \text { DF } & \text { Prob }>\text { F } \\ 1.8051722 & 1.8473 & 2 & 0.1757\end{array}$

Denominator MS Synthesis:

Residual

$\begin{array}{lrrr}\begin{array}{l}\text { Least Squares } \\ \text { Level }\end{array} & \begin{array}{r}\text { Means Table } \\ \text { Least Sq } \\ \text { Mean }\end{array} & \text { Std Error } & \text { Mean } \\ \text { Bottom } & 1.8233333 & 0.20178096 & 1.82333 \\ \text { Top } & 1.4483333 & 0.20178096 & 1.44833 \\ \text { Truck } & 1.2891667 & 0.20178096 & 1.28917\end{array}$

Driver\&Random

Effect Test

Sum of F Ratio DF Prob $>$ F

Squares

$\begin{array}{llll}1.2907056 & 1.3209 & 2 & 0.2825\end{array}$

Denominator MS Synthesis:

Residual

Least Squares Means Table

$\begin{array}{lrrr}\text { Level } & \begin{array}{r}\text { Least Sq } \\ \text { Mean }\end{array} & \text { Std Error } & \text { Mean } \\ \text { Justin } & 1.7658333 & 0.20178096 & 1.76583 \\ \text { Kainoa } & 1.4900000 & 0.20178096 & 1.49000 \\ \text { Tyler } & 1.3050000 & 0.20178096 & 1.30500\end{array}$




\section{$\underline{\text { Average Acceleration of Shock Event Cross Stack }}$}

Response Average Acceleration

Whole Model

Actual by Predicted Plot

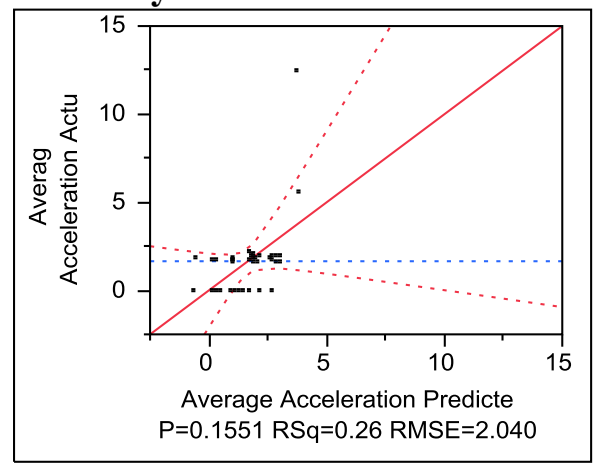

\section{Summary of Fit}

RSquare

0.260939

RSquare Adj

0.108029

Root Mean Square Error

2.04074

Mean of Response

1.650556

Observations (or Sum Wgts)

36

\section{Analysis of Variance}

$\begin{array}{lrrrr}\text { Source } & \text { DF } & \begin{array}{r}\text { Sum of } \\ \text { Squares }\end{array} & \text { Mean Square } & \text { F Ratio } \\ \text { Model } & 6 & 42.64140 & 7.10690 & 1.7065 \\ \text { Error } & 29 & 120.77399 & 4.16462 & \text { Prob > F } \\ \text { C. Total } & 35 & 163.41539 & & 0.1551\end{array}$

\section{Parameter Estimates}

\section{Term}

Intercept

Obstacle Course[ASTM]

Ride Height[Low]

Recorder Location[Bottom]

Recorder Location[Top]

Driver[Justin]

Driver[Kainoa]

$\begin{array}{rrrr}\text { Estimate } & \text { Std Error } & \text { t Ratio } & \text { Prob }>|\mathbf{t}| \\ 1.6505556 & 0.340123 & 4.85 & <.0001^{*} \\ 0.3711111 & 0.340123 & 1.09 & 0.2842 \\ -0.456111 & 0.340123 & -1.34 & 0.1903 \\ 0.5436111 & 0.481007 & 1.13 & 0.2677 \\ 0.5211111 & 0.481007 & 1.08 & 0.2876 \\ -0.388889 & 0.481007 & -0.81 & 0.4254 \\ 0.7369444 & 0.481007 & 1.53 & 0.1363\end{array}$

Expected Mean Squares

The Mean Square per row by the Variance Component per column

\begin{tabular}{|c|c|c|c|c|c|}
\hline EMS & Intercept & Obstacle & Ride Height & \multicolumn{2}{|c|}{ Recorder Driver\&Rando } \\
\hline & & Course & & Location & $\mathbf{m}$ \\
\hline Intercept & 0 & 0 & 0 & 0 & 0 \\
\hline Obstacle & 0 & 18 & 0 & 0 & 0 \\
\hline Course & & & & & \\
\hline Ride Height & 0 & 0 & 18 & 0 & 0 \\
\hline
\end{tabular}




\begin{tabular}{lrrrrr} 
EMS & Intercept & $\begin{array}{r}\text { Obstacle } \\
\text { Course }\end{array}$ & Ride Height & \multicolumn{2}{c}{$\begin{array}{r}\text { Recorder Driver\& Rando } \\
\text { Location }\end{array}$} \\
$\begin{array}{l}\text { Recorder } \\
\text { Location } \\
\text { Driver\&Rando }\end{array}$ & 0 & 0 & 0 & 12 & 0 \\
$m$ & 0 & 0 & 0 & 0 & 12
\end{tabular}

plus 1.0 times Residual Error Variance

Variance Component Estimates

$\begin{array}{lrr}\text { Component } & \begin{array}{r}\text { Var Comp } \\ \text { Est }\end{array} & \begin{array}{r}\text { Percent of } \\ \text { Total }\end{array} \\ \text { Driver\&Random } & 0.06068 & 1.436 \\ \text { Residual } & 4.16462 & 98.564 \\ \text { Total } & 4.225301 & 100.000\end{array}$

These estimates based on equating Mean Squares to Expected Value.

Test Denominator Synthesis

Source

Obstacle Course

Ride Height

Recorder Location

Driver\&Random
MS Den

4.16462

4.16462

4.16462

4.16462
DF Den Denom MS

Synthesis

29 Residual

29 Residual

29 Residual

29 Residual

Tests wrt Random Effects

$\begin{array}{lrrrrr}\text { Source } & \text { SS } & \text { MS Num } & \text { DF Num } & \text { F Ratio } & \text { Prob > F } \\ \text { Obstacle Course } & 4.95804 & 4.95804 & 1 & 1.1905 & 0.2842 \\ \text { Ride Height } & 7.48934 & 7.48934 & 1 & 1.7983 & 0.1903 \\ \text { Recorder Location } & 20.4084 & 10.2042 & 2 & 2.4502 & 0.1039 \\ \text { Driver\&Random } & 9.78557 & 4.89279 & 2 & 1.1748 & 0.3231\end{array}$

Residual by Predicted Plot

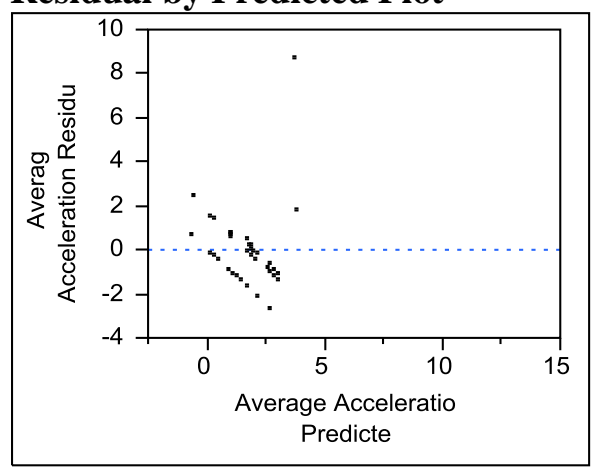




\section{Obstacle Course}

Leverage Plot

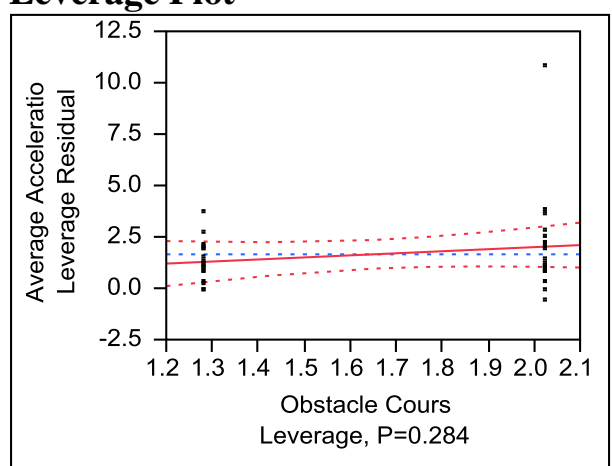

Effect Test

$\begin{array}{rrrr}\begin{array}{r}\text { Sum of } \\ \text { Squares }\end{array} & \text { F Ratio } & \text { DF } & \text { Prob }>\text { F } \\ .9580444 & 1.1905 & 1 & 0.2842\end{array}$

Denominator MS Synthesis:

Residual

$\begin{array}{lrrr}\begin{array}{l}\text { Least Squares Means Table } \\ \text { Level }\end{array} & \begin{array}{r}\text { Least Sq } \\ \text { Mean }\end{array} & \text { Std Error } & \text { Mean } \\ & 2.0216667 & 0.48100706 & 2.02167 \\ \text { ASTM } & 1.2794444 & 0.48100706 & 1.27944 \\ \text { ISTA } & 1.2744\end{array}$

\section{Ride Height}

Leverage Plot

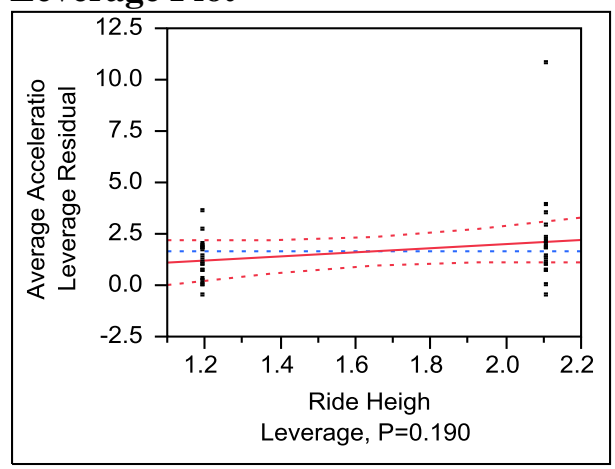

Effect Test

$\begin{array}{rrrr}\begin{array}{r}\text { Sum of } \\ \text { Squares }\end{array} & \text { F Ratio } & \text { DF } & \text { Prob }>\text { F } \\ .4893444 & 1.7983 & 1 & 0.1903\end{array}$

Denominator MS Synthesis:

Residual 


\begin{tabular}{|c|c|c|c|}
\hline \multicolumn{4}{|c|}{ Least Squares Means Table } \\
\hline Level & $\begin{array}{r}\text { Least Sq } \\
\text { Mean }\end{array}$ & Std Error & Mean \\
\hline Low & 1.1944444 & 0.48100706 & 1.19444 \\
\hline High & 2.1066667 & 0.48100706 & 2.10667 \\
\hline
\end{tabular}

Recorder Location

Leverage Plot

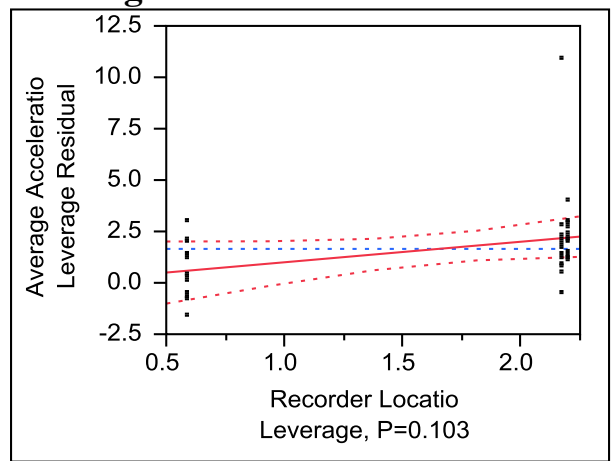

\section{Effect Test}

$\begin{array}{rrrr}\begin{array}{r}\text { Sum of } \\ \text { Squares }\end{array} & \text { F Ratio } & \text { DF } & \text { Prob }>\text { F } \\ 20.408439 & 2.4502 & 2 & 0.1039\end{array}$

Denominator MS Synthesis:

Residual

Least Squares Means Table

Level Least Sq Std Error Mean

$\begin{array}{llll}\text { Bottom } & 2.1941667 & 0.58911093 & 2.19417 \\ \text { Top } & 2.1716667 & 0.58911093 & 2.17167 \\ \text { Truck } & 0.5858333 & 0.58911093 & 0.58583\end{array}$

Driver\&Random

Effect Test

$\begin{array}{rrrr}\begin{array}{r}\text { Sum of } \\ \text { Squares }\end{array} & \text { F Ratio } & \text { DF } & \text { Prob }>\text { F } \\ 9.7855722 & 1.1748 & 2 & 0.3231\end{array}$

Denominator MS Synthesis:

Residual 


$\begin{array}{lrrr}\begin{array}{l}\text { Least Squares } \\ \text { Level }\end{array} & \begin{array}{r}\text { Means Table } \\ \text { Least Sq } \\ \text { Mean }\end{array} & \text { Std Error } & \text { Mean } \\ \text { Justin } & 1.2616667 & 0.58911093 & 1.26167 \\ \text { Kainoa } & 2.3875000 & 0.58911093 & 2.38750 \\ \text { Tyler } & 1.3025000 & 0.58911093 & 1.30250\end{array}$

\section{Average Quantity of Shock Events Column Stack}

Response Quantity of Events

Whole Model

Actual by Predicted Plot

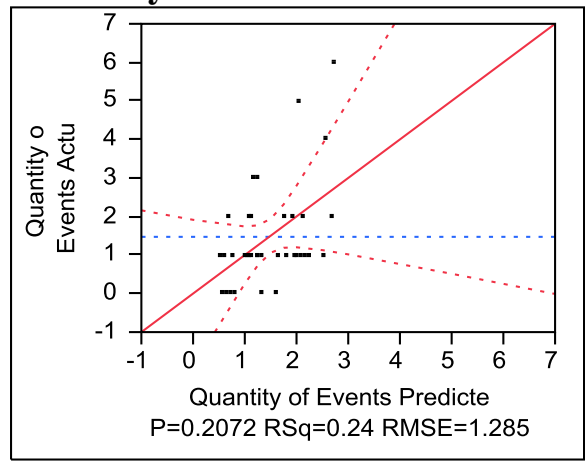

\section{Summary of Fit}

RSquare

0.239082

RSquare Adj

0.081651

Root Mean Square Error

1.285418

Mean of Response

1.472222
Observations (or Sum Wgts)

36

Analysis of Variance

Source DF

Model

\section{6}

29

35

Sum of
Squares
15.055556
47.916667
62.972222

Mean Square

F Ratio

2.50926

1.5186

1.65230

Prob > F

0.2072

Parameter Estimates

Term

Intercept

Obstacle Course[ASTM]

Ride Height[Low]

Recorder Location[Bottom]

Recorder Location[Top]

Driver[Justin]

Driver[Kainoa]

Estimate
1.4722222
0.0277778
-0.083333
0.7777778
-0.138889
0.3611111
-0.222222

Std Error

0.214236

0.214236

0.214236

0.302976

0.302976

0.302976

0.302976

t Ratio

6.87

0.13

$-0.39$

2.57

$-0.46$

1.19

$-0.73$

Prob $>|t|$ $<.0001 *$

0.8977

0.7001

$0.0157 *$

0.6501

0.2430

0.4692 


\section{Expected Mean Squares}

The Mean Square per row by the Variance Component per column

$\begin{array}{lrrrrr}\text { EMS } & \begin{array}{r}\text { Intercept } \\ \text { Obstacle } \\ \text { Course }\end{array} & \text { Ride Height } & \begin{array}{r}\text { Recorder Driver\&Rando } \\ \text { Location }\end{array} & \begin{array}{r}\text { m } \\ \text { Intercept } \\ \text { Obstacle }\end{array} \\ \text { Course } & 0 & 0 & 0 & 0 & 0 \\ \text { Ride Height } & 0 & 18 & 0 & 0 & 0 \\ \text { Recorder } & 0 & 0 & 18 & 0 & 0 \\ \text { Location } & 0 & 0 & 0 & 12 & 12 \\ \text { Driver\&Rando } & 0 & 0 & 0 & 0 & \end{array}$

$\mathrm{m}$

plus 1.0 times Residual Error Variance

$\begin{array}{lrr}\begin{array}{l}\text { Variance Component Estimates } \\ \text { Component }\end{array} & \begin{array}{r}\text { Var Comp } \\ \text { Est }\end{array} & \begin{array}{r}\text { Percent of } \\ \text { Total }\end{array} \\ \text { Driver\&Random } & -0.03815 & -2.364 \\ \text { Residual } & 1.652299 & 102.364 \\ \text { Total } & 1.614144 & 100.000\end{array}$

These estimates based on equating Mean Squares to Expected Value.

Test Denominator Synthesis

Source

Obstacle Course

Ride Height

Recorder Location

Driver\&Random
MS Den

1.6523

1.6523

1.6523

1.6523
DF Den Denom MS

Synthesis

29 Residual

29 Residual

29 Residual

29 Residual

Tests wrt Random Effects

\section{Source}

Obstacle Course

Ride Height

Recorder Location

Driver\&Random

$\begin{array}{rr}\text { SS } & \text { MS Num } \\ 0.02778 & 0.02778 \\ 0.25 & 0.25 \\ 12.3889 & 6.19444 \\ 2.38889 & 1.19444\end{array}$

$\begin{array}{rr}\text { DF Num } & \text { F Ratio } \\ 1 & 0.0168 \\ 1 & 0.1513 \\ 2 & 3.7490 \\ 2 & 0.7229\end{array}$

Prob > F

0.8977

0.7001

$0.0356^{*}$

0.4939 
Residual by Predicted Plot

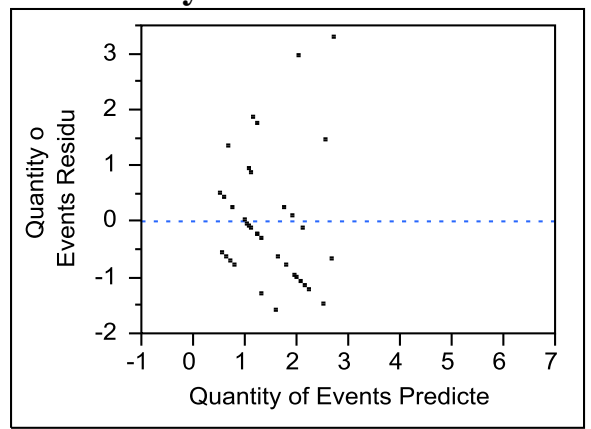

Obstacle Course

Leverage Plot

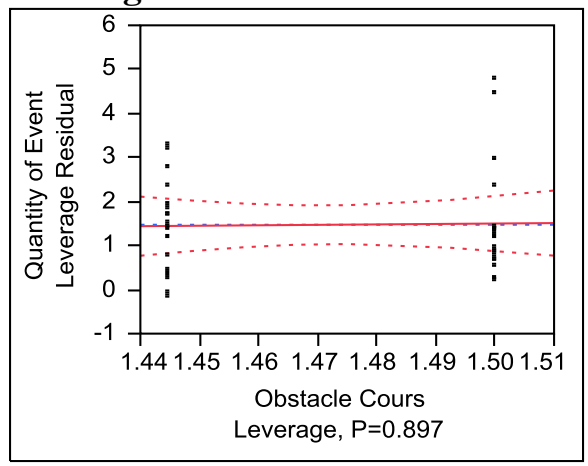

\section{Effect Test}

$\begin{array}{rrcr}\begin{array}{r}\text { Sum of } \\ \text { Squares }\end{array} & \text { F Ratio } & \text { DF } & \text { Prob }>\text { F } \\ 0.02777778 & 0.0168 & 1 & 0.8977\end{array}$

Denominator MS Synthesis:

Residual

Least Squares Means Table

Level

ASTM

ISTA

\section{Least Sq}

Mean

1.5000000

1.4444444
Std Error Mean

$0.30297587 \quad 1.50000$

$0.30297587 \quad 1.44444$ 
Ride Height

Leverage Plot

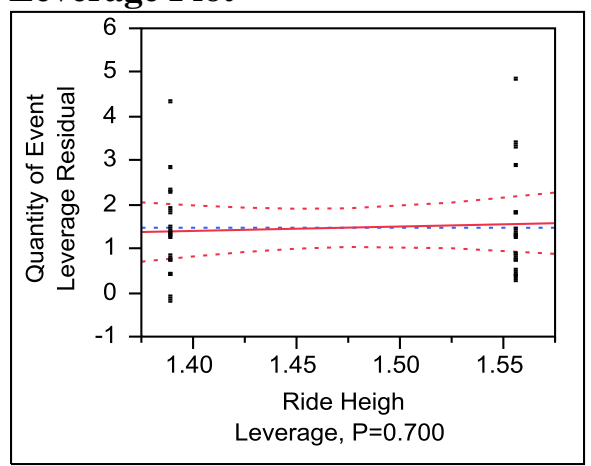

Effect Test

Sum of F Ratio DF Prob $>$ F

Squares

$\begin{array}{llll}0.25000000 & 0.1513 & 1 & 0.7001\end{array}$

Denominator MS Synthesis:

Residual

\begin{tabular}{|c|c|c|c|}
\hline \multicolumn{4}{|c|}{ Least Squares Means Table } \\
\hline Level & $\begin{array}{r}\text { Least Sq } \\
\text { Mean }\end{array}$ & Std Error & Mean \\
\hline Low & 1.3888889 & 0.30297587 & 1.38889 \\
\hline High & 1.5555556 & 0.30297587 & 1.55556 \\
\hline
\end{tabular}

Recorder Location

Leverage Plot

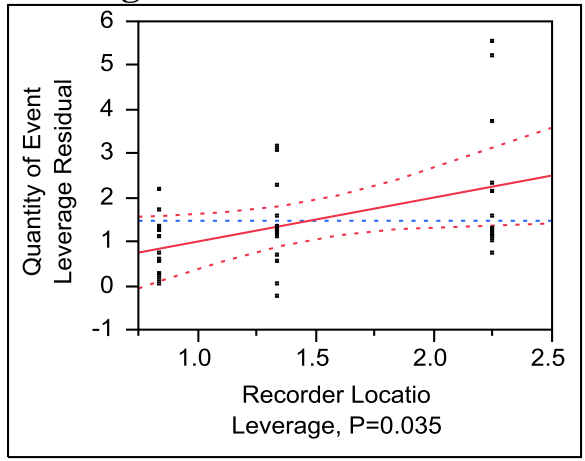




$\begin{array}{rrrr}\text { Effect Test } & & & \\ \begin{array}{r}\text { Sum of } \\ \text { Squares }\end{array} & \text { F Ratio } & \text { DF } & \text { Prob }>\text { F } \\ 12.388889 & 3.7490 & 2 & 0.0356^{*}\end{array}$

Denominator MS Synthesis:

Residual

Least Squares Means Table

Level Least $\mathrm{Sq}$

Mean

Std Error Mean

$\begin{array}{llll}\text { Bottom } & 2.2500000 & 0.37106815 & 2.25000\end{array}$

$\begin{array}{llll}\text { Top } & 1.3333333 & 0.37106815 & 1.33333\end{array}$

$\begin{array}{llll}\text { Truck } & 0.8333333 & 0.37106815 & 0.83333\end{array}$

Driver\&Random

Effect Test

$\begin{array}{rrrr}\begin{array}{r}\text { Sum of } \\ \text { Squares }\end{array} & \text { F Ratio } & \text { DF } & \text { Prob }>\text { F } \\ 2.3888889 & 0.7229 & 2 & 0.4939\end{array}$

Denominator MS Synthesis:

Residual

Least Squares Means Table

Level

Justin

Kainoa

Tyler
Least Sq

Mean

1.8333333

1.2500000

1.3333333
Std Error Mean

$0.37106815 \quad 1.83333$

$0.37106815 \quad 1.25000$

$0.37106815 \quad 1.33333$ 


\section{Average Quantity of Shock Events Cross Stack}

Response Quantity of Events

Whole Model

Actual by Predicted Plot

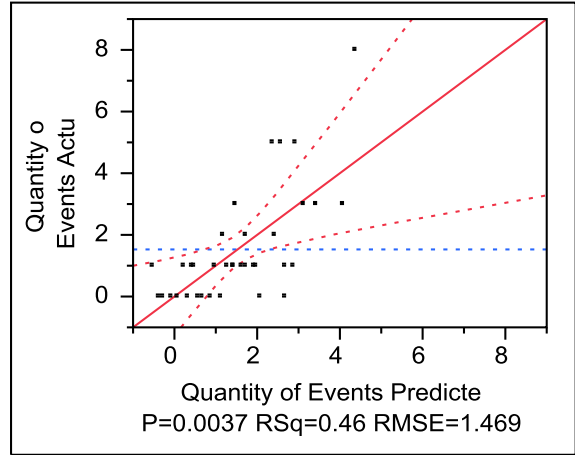

\section{Summary of Fit}

RSquare

0.464498

RSquare Adj

0.353704

Root Mean Square Error

1.469681

Mean of Response

1.527778

Observations (or Sum Wgts)

36

\section{Analysis of Variance}

Source DF

$\begin{array}{lrr} & & \text { Squares } \\ \text { Model } & 6 & 54.33333 \\ \text { Error } & 29 & 62.63889 \\ \text { C. Total } & 35 & 116.97222\end{array}$

Mean Square F Ratio

$\begin{array}{rr}9.05556 & 4.1925 \\ 2.15996 & \text { Prob > F } \\ 0.0037 *\end{array}$

Parameter Estimates

Term

Intercept

Obstacle Course[ASTM]

Ride Height[Low]

Recorder Location[Bottom]

Recorder Location[Top]

Driver[Justin]

Driver[Kainoa]

$\begin{array}{rrrr}\text { Estimate } & \text { Std Error } & \text { t Ratio } & \text { Prob }>|\mathbf{t}| \\ 1.5277778 & 0.244947 & 6.24 & <.0001^{*} \\ -0.138889 & 0.244947 & -0.57 & 0.5751 \\ -0.472222 & 0.244947 & -1.93 & 0.0637 \\ 1.1388889 & 0.346407 & 3.29 & 0.0026^{*} \\ -0.277778 & 0.346407 & -0.80 & 0.4291 \\ -0.611111 & 0.346407 & -1.76 & 0.0882 \\ -0.444444 & 0.346407 & -1.28 & 0.2096\end{array}$

Expected Mean Squares

The Mean Square per row by the Variance Component per column

\begin{tabular}{|c|c|c|c|c|c|}
\hline EMS & Intercept & Obstacle & Ride Height & \multicolumn{2}{|c|}{ Recorder Driver\&Rando } \\
\hline & & Course & & Location & $\mathbf{m}$ \\
\hline Intercept & 0 & 0 & 0 & 0 & 0 \\
\hline Obstacle & 0 & 18 & 0 & 0 & 0 \\
\hline Course & & & & & \\
\hline Ride Height & 0 & 0 & 18 & 0 & 0 \\
\hline
\end{tabular}




\begin{tabular}{lrrrrr} 
EMS & Intercept & $\begin{array}{r}\text { Obstacle } \\
\text { Course }\end{array}$ & Ride Height & \multicolumn{2}{c}{$\begin{array}{r}\text { Recorder Driver\& Rando } \\
\text { Location }\end{array}$} \\
$\begin{array}{l}\text { Recorder } \\
\text { Location } \\
\text { Driver\&Rando }\end{array}$ & 0 & 0 & 0 & 12 & 0 \\
$m$ & 0 & 0 & 0 & 0 & 12
\end{tabular}

plus 1.0 times Residual Error Variance

$\begin{array}{lrr}\begin{array}{l}\text { Variance Component Estimates } \\ \text { Component }\end{array} & \begin{array}{r}\text { Var Comp } \\ \text { Est }\end{array} & \begin{array}{r}\text { Percent of } \\ \text { Total }\end{array} \\ \text { Driver\&Random } & 0.662596 & 23.475 \\ \text { Residual } & 2.159962 & 76.525 \\ \text { Total } & 2.822557 & 100.000\end{array}$

These estimates based on equating Mean Squares to Expected Value.

Test Denominator Synthesis

Source

Obstacle Course

Ride Height

Recorder Location

Driver\&Random
MS Den

2.15996

2.15996

2.15996

2.15996
DF Den Denom MS

Synthesis

29 Residual

29 Residual

29 Residual

29 Residual

Tests wrt Random Effects

$\begin{array}{lrrrrr}\text { Source } & \text { SS } & \text { MS Num } & \text { DF Num } & \text { F Ratio } & \text { Prob > F } \\ \text { Obstacle Course } & 0.69444 & 0.69444 & 1 & 0.3215 & 0.5751 \\ \text { Ride Height } & 8.02778 & 8.02778 & 1 & 3.7166 & 0.0637 \\ \text { Recorder Location } & 25.3889 & 12.6944 & 2 & 5.8772 & 0.0072^{*} \\ \text { Driver\&Random } & 20.2222 & 10.1111 & 2 & 4.6812 & 0.0173^{*}\end{array}$

Residual by Predicted Plot

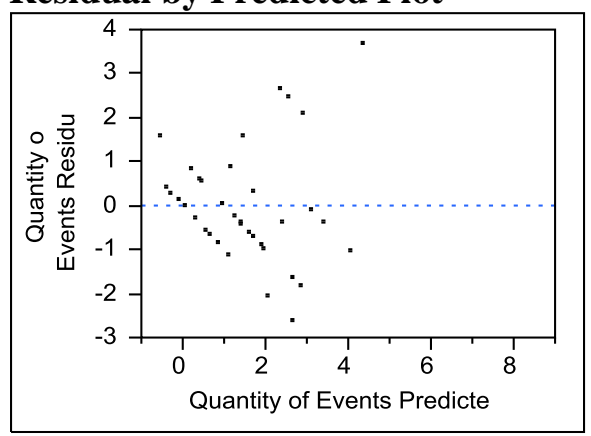


Obstacle Course

Leverage Plot

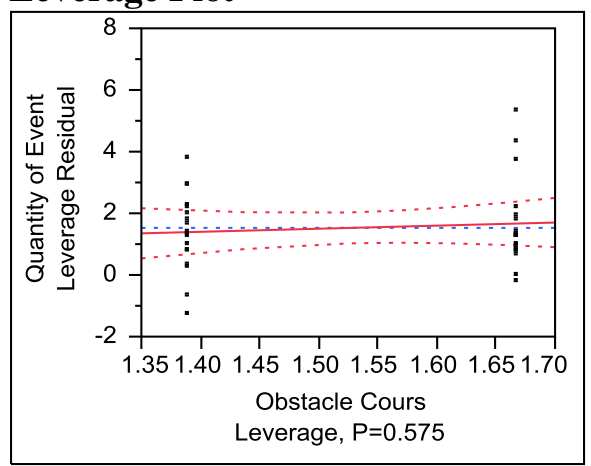

Effect Test

Sum of F Ratio DF Prob $>$ F

Squares

$\begin{array}{llll}0.69444444 & 0.3215 & 1 & 0.5751\end{array}$

Denominator MS Synthesis:

Residual

Least Squares Means Table

Level Least $\mathrm{Sq}$

Std Error Mean

Mean

$\begin{array}{llll}\text { ASTM } & 1.3888889 & 0.34640709 & 1.38889\end{array}$

$\begin{array}{llll}\text { ISTA } & 1.6666667 & 0.34640709 & 1.66667\end{array}$

Ride Height

Leverage Plot

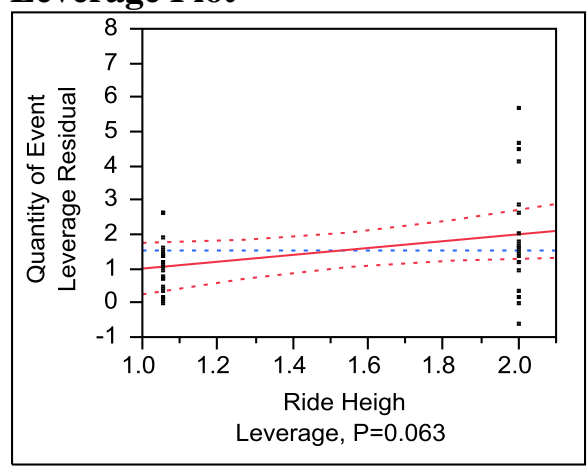

Effect Test

Sum of F Ratio DF Prob $>$ F

Squares

$\begin{array}{llll}8.0277778 & 3.7166 & 1 & 0.0637\end{array}$ 
Denominator MS Synthesis:

Residual

\begin{tabular}{lrrr}
\multicolumn{2}{l}{ Least Squares Means Table } & & \\
Level & $\begin{array}{r}\text { Least Sq } \\
\text { Mean }\end{array}$ & Std Error & Mean \\
Low & 1.0555556 & 0.34640709 & 1.05556 \\
High & 2.0000000 & 0.34640709 & 2.00000
\end{tabular}

Recorder Location

Leverage Plot

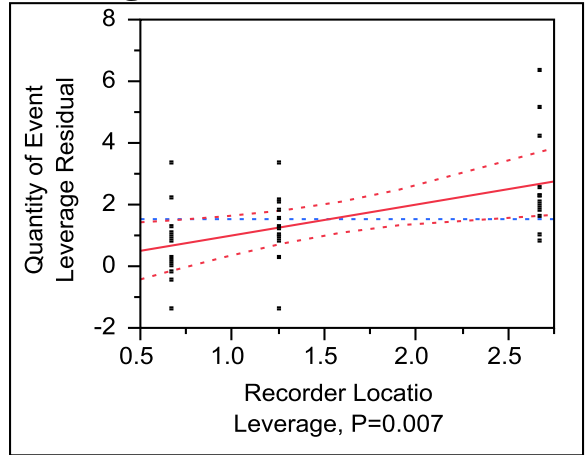

Effect Test

Sum of F Ratio DF Prob $>$ F

Squares

$\begin{array}{llll}25.388889 & 5.8772 & 2 & 0.0072 *\end{array}$

Denominator MS Synthesis:

Residual

Least Squares Means Table

Level Least Sq Std Error Mean

Mean

$\begin{array}{llll}\text { Bottom } & 2.6666667 & 0.42426031 & 2.66667\end{array}$

$\begin{array}{llll}\text { Top } & 1.2500000 & 0.42426031 & 1.25000\end{array}$

$\begin{array}{llll}\text { Truck } & 0.6666667 & 0.42426031 & 0.66667\end{array}$

Driver\&Random

Effect Test

$\begin{array}{rrrr}\begin{array}{r}\text { Sum of } \\ \text { Squares }\end{array} & \text { F Ratio } & \text { DF } & \text { Prob }>\text { F } \\ 20.222222 & 4.6812 & 2 & 0.0173^{*}\end{array}$

Denominator MS Synthesis:

Residual 


$\begin{array}{lrrr}\begin{array}{l}\text { Least Squares } \\ \text { Level }\end{array} & \begin{array}{r}\text { Means Table } \\ \text { Least Sq } \\ \text { Mean }\end{array} & \text { Std Error } & \text { Mean } \\ & 0.9166667 & 0.42426031 & 0.91667 \\ \text { Justin } & 1.0833333 & 0.42426031 & 1.08333 \\ \text { Kainoa } & 2.5833333 & 0.42426031 & 2.58333 \\ \text { Tyler } & & & \end{array}$

\section{Slippage Delta Column Stack}

\section{Response Slippage Delta}

Whole Model

Actual by Predicted Plot

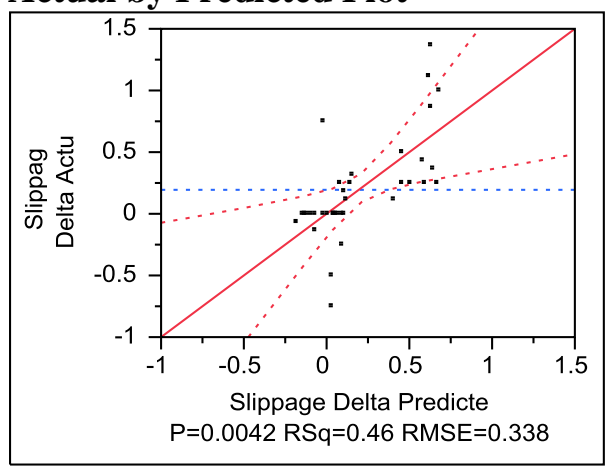

\section{Summary of Fit}

RSquare

0.458979

RSquare Adj

0.347044

Root Mean Square Error

0.338434

Mean of Response

0.194472

Observations (or Sum Wgts) 


$\begin{array}{lrrrr}\begin{array}{l}\text { Analysis of Variance } \\ \text { Source }\end{array} & \text { DF } & \begin{array}{r}\text { Sum of } \\ \text { Squares }\end{array} & \text { Mean Square } & \text { F Ratio } \\ \text { Model } & 6 & 2.8179030 & 0.469651 & 4.1004 \\ \text { Error } & 29 & 3.3215980 & 0.114538 & \begin{array}{r}\text { Prob }>\text { F } \\ \text { C. Total }\end{array} \\ & 35 & 6.1395010 & & 0.0042^{*}\end{array}$

Parameter Estimates

Term

$\begin{array}{rrrr}\text { Estimate } & \text { Std Error } & \text { t Ratio } & \text { Prob }>|\mathbf{t}| \\ 0.1944722 & 0.056406 & 3.45 & 0.0017^{*} \\ -0.020861 & 0.056406 & -0.37 & 0.7142 \\ 0.0243056 & 0.056406 & 0.43 & 0.6697 \\ 0.3732778 & 0.07977 & 4.68 & <.0001^{*} \\ -0.220556 & 0.07977 & -2.76 & 0.0098^{*} \\ -0.116389 & 0.07977 & -1.46 & 0.1553 \\ 0.0503611 & 0.07977 & 0.63 & 0.5328\end{array}$

Intercept

Obstacle Course[ASTM]

Ride Height[Low]

Sector[Back]

Sector[Front]

Driver[Justin]

0.0503611

0.07977

0.63

0.5328

Expected Mean Squares

The Mean Square per row by the Variance Component per column

$\begin{array}{lrrrrr}\text { EMS } & \text { Intercept } & \begin{array}{r}\text { Obstacle } \\ \text { Course }\end{array} & \text { Ride Height } & \begin{array}{r}\text { Sector Driver\&Rando } \\ \text { m }\end{array} \\ \text { Intercept } & 0 & 0 & 0 & 0 & 0 \\ \text { Obstacle } & 0 & 18 & 0 & 0 & 0 \\ \text { Course } & & 0 & 18 & 0 & 0 \\ \text { Ride Height } & 0 & 0 & 0 & 12 & 0 \\ \text { Sector } & 0 & 0 & 0 & 0 & 12 \\ \text { Driver\&Rando } & 0 & & & \end{array}$

$\mathrm{m}$

plus 1.0 times Residual Error Variance

$\begin{array}{lrr}\begin{array}{l}\text { Variance Component Estimates } \\ \text { Component }\end{array} & \begin{array}{r}\text { Est } \\ \text { Var Comp }\end{array} & \begin{array}{r}\text { Percent of } \\ \text { Total }\end{array} \\ \text { Driver\&Random } & 0.000676 & 0.587 \\ \text { Residual } & 0.114538 & 99.413 \\ \text { Total } & 0.115214 & 100.000\end{array}$

These estimates based on equating Mean Squares to Expected Value.

Test Denominator Synthesis

Source

Obstacle Course

Ride Height

Sector

Driver\&Random
MS Den

0.11454

0.11454

0.11454

0.11454

\section{DF Den Denom MS}

Synthesis

29 Residual

29 Residual

29 Residual

29 Residual 
Tests wrt Random Effects

Source

Obstacle Course

Ride Height

Sector

Driver\&Random

$\begin{array}{rr}\text { SS } & \text { MS Num } \\ 0.01567 & 0.01567 \\ 0.02127 & 0.02127 \\ 2.53566 & 1.26783 \\ 0.24531 & 0.12265\end{array}$

DF Num

1

F Ratio

0.1368

0.1857

11.0691

$\begin{array}{lr}2 & 11.0691 \\ 2 & 1.0709\end{array}$
Prob > F

0.7142

0.6697

$0.0003^{*}$

0.3559

\section{Residual by Predicted Plot}

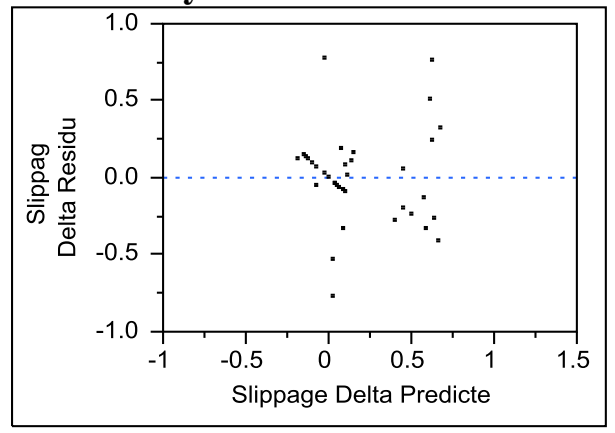

\section{Obstacle Course}

Leverage Plot

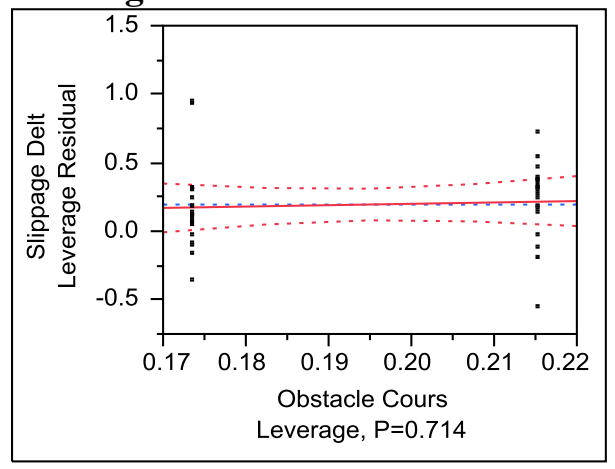

\section{Effect Test}

$\begin{array}{rrrr}\begin{array}{r}\text { Sum of } \\ \text { Squares }\end{array} & \text { F Ratio } & \text { DF } & \text { Prob }>\text { F } \\ 0.01566669 & 0.1368 & 1 & 0.7142\end{array}$

Denominator MS Synthesis:

Residual

Least Squares Means Table

Level

Least Sq

Mean

ASTM

0.17361111
Std Error Mean

$0.07976976 \quad 0.173611$ 


$\begin{array}{lrrrr}\text { Level } & \begin{array}{r}\text { Least Sq } \\ \text { Mean }\end{array} & \text { Std Error } & \text { Mean } \\ \text { ISTA } & 0.21533333 & 0.07976976 & 0.215333\end{array}$

Ride Height

Leverage Plot

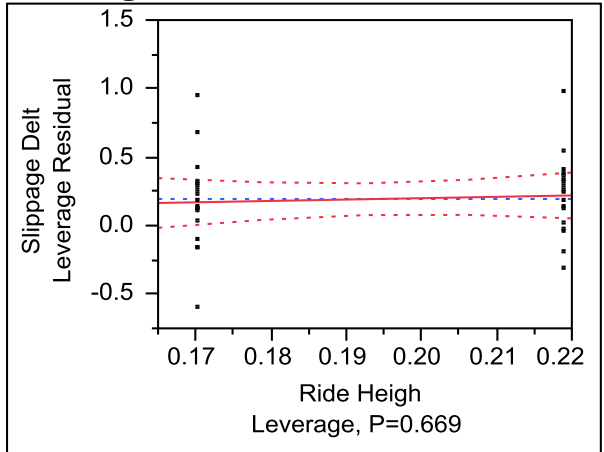

Effect Test

Sum of F Ratio DF Prob $>$ F

Squares

$\begin{array}{llll}0.02126736 & 0.1857 & 1 & 0.6697\end{array}$

Denominator MS Synthesis:

Residual

Least Squares Means Table

Level Least Sq

Std Error Mean

Mean

Low $\quad 0.21877778$

$0.07976976 \quad 0.218778$

High

0.17016667

0.07976976

0.170167

Sector

Leverage Plot

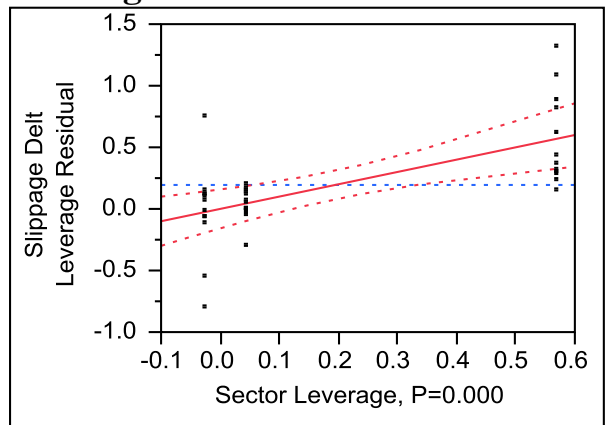

Effect Test

Sum of F Ratio DF Prob $>$ F

Squares 


$\begin{array}{rccc}\text { Sum of } & \text { F Ratio } & \text { DF } & \text { Prob }>\text { F } \\ \text { Squares } & & & \\ 2.5356616 & 11.0691 & 2 & 0.0003^{*}\end{array}$

Denominator MS Synthesis:

Residual

\begin{tabular}{|c|c|c|c|c|c|}
\hline \multicolumn{6}{|c|}{ Least Squares Means Table } \\
\hline Level & \multicolumn{2}{|c|}{$\begin{array}{c}\text { Least Sq } \\
\text { Mean }\end{array}$} & \multicolumn{2}{|c|}{ Std Error } & Mean \\
\hline Back & \multicolumn{2}{|c|}{0.5677500} & \multicolumn{2}{|c|}{0.09769760} & 0.56775 \\
\hline Front & \multicolumn{2}{|c|}{-0.0260833} & \multicolumn{2}{|c|}{0.09769760} & -0.02608 \\
\hline Middle & \multicolumn{2}{|c|}{0.0417500} & \multicolumn{2}{|c|}{0.09769760} & 0.04175 \\
\hline \multicolumn{6}{|c|}{ Driver\&Random } \\
\hline \multicolumn{6}{|c|}{ Effect Test } \\
\hline \multicolumn{2}{|c|}{$\begin{array}{r}\text { Sum of } \\
\text { Squares }\end{array}$} & F Ratio & DF & Prob & \\
\hline \multicolumn{2}{|c|}{0.24530739} & 1.0709 & 2 & 0.3 & \\
\hline \multicolumn{6}{|c|}{$\begin{array}{l}\text { Denominator MS Synthesis: } \\
\text { Residual }\end{array}$} \\
\hline \multicolumn{6}{|c|}{ Least Squares Means Table } \\
\hline Level & \multicolumn{2}{|c|}{$\begin{array}{c}\text { Least Sq } \\
\text { Mean }\end{array}$} & \multicolumn{2}{|c|}{ Std Error } & Mean \\
\hline Justin & & 8333 & 0.09 & 69760 & 0.078083 \\
\hline Kainoa & & 3333 & 0.09 & 69760 & 0.244833 \\
\hline Tyler & 0.2 & 0000 & 0.09 & 69760 & 0.260500 \\
\hline
\end{tabular}




\section{Slippage Delta Cross Stack}

\section{Response Delta}

Whole Model

Actual by Predicted Plot

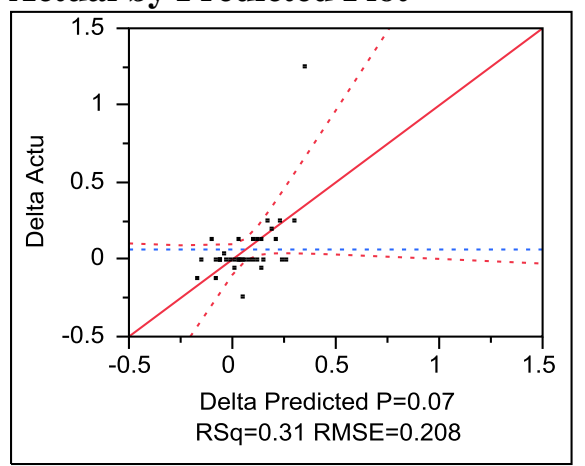

\section{Summary of Fit}

RSquare

RSquare Adj

Root Mean Square Error

Mean of Response

Observations (or Sum Wgts)
0.308376

0.165281

0.208872

0.065056

36

Analysis of Variance

Source DF

Model

DF

Error

$6 \quad 0.5641190$

Sum of

Mean Square

F Ratio

Squares

C. Total

29

1.2652029

0.094020

2.1550

0.043628

Prob > F

1.8293219

0.0770

\section{Parameter Estimates}

\section{Term}

Intercept

Obstacle Course[ASTM]

Ride Height[Low]

Sector[Back]

Sector[Front]

Driver[Justin]

Driver[Kainoa]

$\begin{array}{rrrr}\text { Estimate } & \text { Std Error } & \text { t Ratio } & \text { Prob }>|\mathbf{t}| \\ 0.0650556 & 0.034812 & 1.87 & 0.0718 \\ -0.054611 & 0.034812 & -1.57 & 0.1276 \\ -0.046056 & 0.034812 & -1.32 & 0.1962 \\ 0.1276944 & 0.049232 & 2.59 & 0.0147^{*} \\ -0.075556 & 0.049232 & -1.53 & 0.1357 \\ -0.062556 & 0.049232 & -1.27 & 0.2140 \\ 0.0078611 & 0.049232 & 0.16 & 0.8742\end{array}$

\section{Expected Mean Squares}

The Mean Square per row by the Variance Component per column

\begin{tabular}{|c|c|c|c|c|}
\hline EMS & Intercept & $\begin{array}{r}\text { Obstacle } \\
\text { Course }\end{array}$ & Ride Height & Sector Driver\&Rando \\
\hline Intercept & 0 & 0 & 0 & 0 \\
\hline Obstacle & 0 & 18 & 0 & 0 \\
\hline
\end{tabular}




\section{EMS}

Intercept

Course

Ride Height

Sector

Driver\&Rando

$\mathrm{m}$

plus 1.0 times Residual Error Variance

\section{Obstacle Ride Height}

Course

0

0

0

0
0
0

18

0

0

$\begin{array}{ll}0 & 18 \\ 0 & 0\end{array}$

Sector Driver\&Rando

m

0

0

12

$\begin{array}{lrr}\begin{array}{l}\text { Variance Component Estimates } \\ \text { Component }\end{array} & \begin{array}{r}\text { Var Comp } \\ \text { Est }\end{array} & \begin{array}{r}\text { Percent of } \\ \text { Total }\end{array} \\ \text { Driver\&Random } & -0.00015 & -0.351 \\ \text { Residual } & 0.043628 & 100.351 \\ \text { Total } & 0.043475 & 100.000\end{array}$

These estimates based on equating Mean Squares to Expected Value.

Test Denominator Synthesis

\section{Source}

Obstacle Course

Ride Height

Sector

Driver\&Random
MS Den

0.04363

0.04363

0.04363

0.04363
DF Den Denom MS Synthesis

29 Residual

29 Residual

29 Residual

29 Residual

\section{Tests wrt Random Effects}

\section{Source}

Obstacle Course

Ride Height

Sector

Driver\&Random

\section{Residual by Predicted Plot}

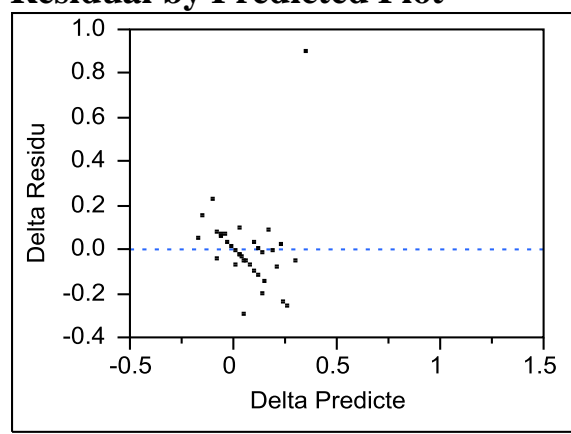

SS MS Num

0.10737

0.07636

0.2968

0.0836

0.10737

0.07636

0.1484

0.0418

$\begin{array}{rr}\text { DF Num } & \text { F Ratio } \\ 1 & 2.4609 \\ 1 & 1.7503 \\ 2 & 3.4015 \\ 2 & 0.9581\end{array}$

Prob > F

0.1276

0.1962

$0.0471 *$

0.3954 


\section{Obstacle Course}

\section{Leverage Plot}

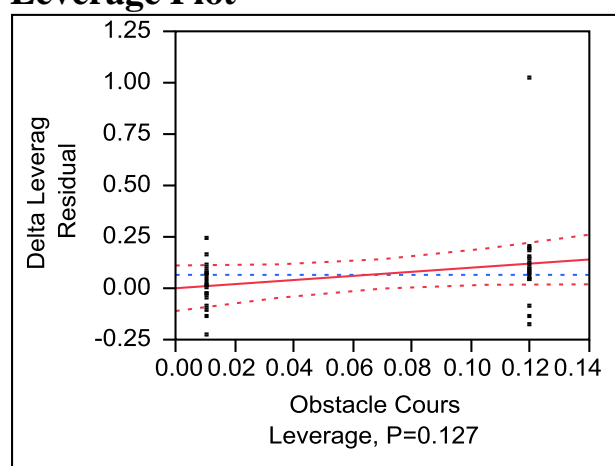

\section{Effect Test}

Sum of F Ratio DF Prob $>$ F

Squares

$\begin{array}{llll}0.10736544 & 2.4609 & 1 & 0.1276\end{array}$

Denominator MS Synthesis:

Residual

Least Squares Means Table

$\begin{array}{lrrr}\text { Level } & \begin{array}{r}\text { Least Sq } \\ \text { Mean }\end{array} & \text { Std Error } & \text { Mean } \\ \text { ASTM } & 0.01044444 & 0.04923170 & 0.010444 \\ \text { ISTA } & 0.11966667 & 0.04923170 & 0.119667\end{array}$

\section{Ride Height}

Leverage Plot

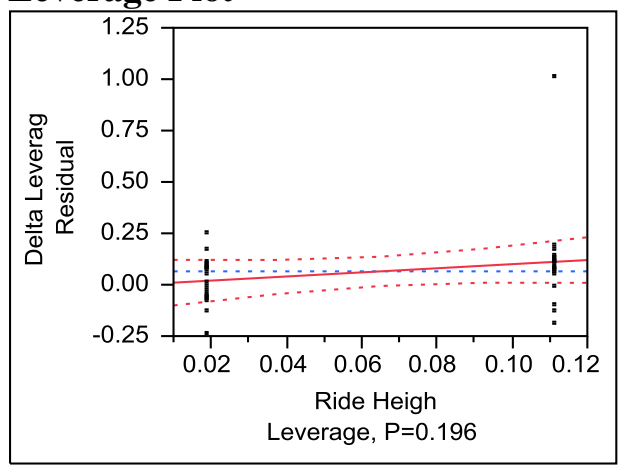

\section{Effect Test}

Sum of F Ratio DF Prob $>$ F

Squares

$\begin{array}{llll}0.07636011 & 1.7503 & 1 & 0.1962\end{array}$


Denominator MS Synthesis:

Residual

\begin{tabular}{|c|c|c|c|}
\hline \multicolumn{4}{|c|}{ Least Squares Means Table } \\
\hline Level & $\begin{array}{r}\text { Least Sq } \\
\text { Mean }\end{array}$ & Std Error & Mean \\
\hline Low & 0.01900000 & 0.04923170 & 0.019000 \\
\hline High & 0.11111111 & 0.04923170 & 0.111111 \\
\hline
\end{tabular}

Sector

Leverage Plot

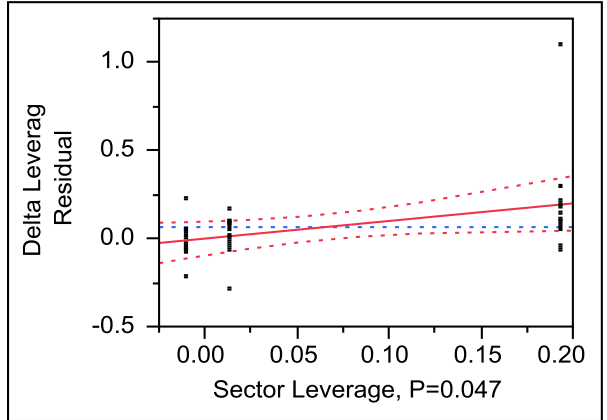

Effect Test

Sum of F Ratio DF Prob $>$ F

Squares

$\begin{array}{llll}0.29679572 & 3.4015 & 2 & 0.0471^{*}\end{array}$

Denominator MS Synthesis:

Residual

Least Squares Means Table

$\begin{array}{lrrr}\text { Level } & \begin{array}{r}\text { Least Sq } \\ \text { Mean }\end{array} & \text { Std Error } & \text { Mean } \\ & 0.1927500 & 0.06029627 & 0.19275 \\ \text { Back } & -0.0105000 & 0.06029627 & -0.01050 \\ \text { Front } & 0.0129167 & 0.06029627 & 0.01292 \\ \text { Middle } & & & \end{array}$

\section{Driver\&Random}

Effect Test

Sum of F Ratio DF Prob $>$ F

Squares

$\begin{array}{llll}0.08359772 & 0.9581 & 2 & 0.3954\end{array}$

Denominator MS Synthesis:

Residual 


$\begin{array}{lrrr}\begin{array}{l}\text { Least Squares Means Table } \\ \text { Level }\end{array} & \begin{array}{r}\text { Least Sq } \\ \text { Mean }\end{array} & \text { Std Error } & \text { Mean } \\ & 0.00250000 & 0.06029627 & 0.002500 \\ \text { Justin } & 0.07291667 & 0.06029627 & 0.072917 \\ \text { Kainoa } & 0.07297 & 0.119750 \\ \text { Tyler } & 0.11975000 & 0.06029627 & \end{array}$

Film Containment Force Column Stack

Response Force Value

Whole Model

Actual by Predicted Plot

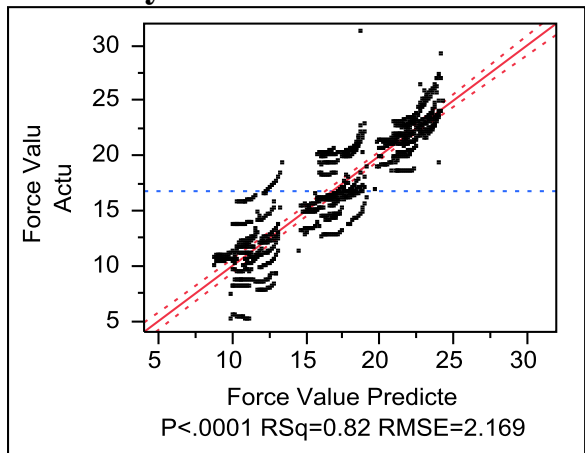

\section{Summary of Fit}

RSquare

0.820915 
RSquare Adj

Root Mean Square Error

Mean of Response

Observations (or Sum Wgts)
0.819085

2.169171

16.78028

792

$\begin{array}{lrrrr}\begin{array}{l}\text { Analysis of Variance } \\ \text { Source }\end{array} & \text { DF } & \begin{array}{r}\text { Sum of } \\ \text { Squares }\end{array} & \text { Mean Square } & \text { F Ratio } \\ \text { Model } & 8 & 16888.420 & 2111.05 & 448.6537 \\ \text { Error } & 783 & 3684.254 & 4.71 & \text { Prob > F } \\ \text { C. Total } & 791 & 20572.674 & & <.0001^{*}\end{array}$

Parameter Estimates

Term

Intercept

Obstacle Course[ASTM]

Ride Height[Low]

Handling[After]

Load Cell Position[Bottom]

Load Cell Position[Middle]

Time

Driver[Justin]

Driver[Kainoa]
Estimate

17.406098

0.0357828

0.1191162

$-0.883207$

$-5.598232$

5.3644949

$-0.004172$

0.3111616

0.4756313
Std Error

0.1442

0.077078

0.077078

0.077078

0.109005

0.109005

0.000812

0.109005

0.109005

$\begin{array}{rr}\text { t Ratio } & \text { Prob }>|\mathbf{t}| \\ 120.71 & <.0001^{*} \\ 0.46 & 0.6426 \\ 1.55 & 0.1227 \\ -11.46 & <.0001^{*} \\ -51.36 & <.0001^{*} \\ 49.21 & <.0001^{*} \\ -5.14 & <.0001^{*} \\ 2.85 & 0.0044^{*} \\ 4.36 & <.0001^{*}\end{array}$

\section{Expected Mean Squares}

The Mean Square per row by the Variance Component per column

$\begin{array}{lrrrrr}\text { EMS } & \text { Intercept } & \begin{array}{r}\text { Obstacle } \\ \text { Course }\end{array} & \text { Ride Height } & \text { Handling } & \begin{array}{r}\text { Load Cell } \\ \text { Position }\end{array} \\ \text { Intercept } & 0 & 0 & 0 & 0 & 0 \\ \text { Obstacle } & 0 & 396 & 0 & 0 & 0 \\ \text { Course } & & & & & \\ \text { Ride Height } & 0 & 0 & 396 & 0 & 0 \\ \text { Handling } & 0 & 0 & 0 & 396 & 0 \\ \text { Load Cell } & 0 & 0 & 0 & 0 & 264 \\ \text { Position } & 0 & 0 & 0 & 0 & 0 \\ \text { Time } & 0 & 0 & 0 & 0 & 0 \\ \text { Driver\&Rando } & 0 & & & & \end{array}$

$\mathrm{m}$

plus 1.0 times Residual Error Variance

$\begin{array}{lrr}\begin{array}{l}\text { Variance Component Estimates } \\ \text { Component }\end{array} & \begin{array}{r}\text { Var Comp } \\ \text { Est }\end{array} & \begin{array}{r}\text { Percent of } \\ \text { Total }\end{array} \\ \text { Driver\&Random } & 0.453222 & 8.786 \\ \text { Residual } & 4.705305 & 91.214 \\ \text { Total } & 5.158527 & 100.000\end{array}$

These estimates based on equating Mean Squares to Expected Value. 
Test Denominator Synthesis

Source

Obstacle Course

Ride Height

Handling

Load Cell Position

Time

Driver\&Random
MS Den

4.7053

4.7053

4.7053

4.7053

4.7053

4.7053

\section{DF Den Denom MS}

Synthesis

783 Residual

783 Residual

783 Residual

783 Residual

783 Residual

783 Residual

\section{Tests wrt Random Effects}

Source

Obstacle Course

Ride Height

Handling

Load Cell Position

Time

Driver\&Random

\section{SS}

1.01409

11.2374

617.803

15885.6

124.075

248.712

MS Num
1.01409
11.2374
617.803
7942.79
124.075
124.356

DF Nu

$$
\begin{array}{r}
\text { Prob > F } \\
0.6426 \\
0.1227 \\
<.0001 * \\
<.0001 * \\
<.0001 * \\
<.0001 *
\end{array}
$$

\section{Residual by Predicted Plot}

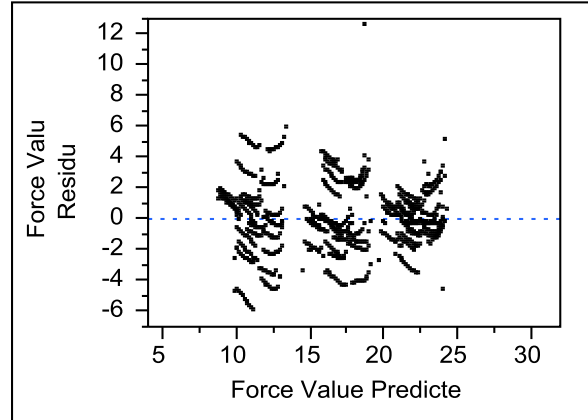

Obstacle Course

Leverage Plot

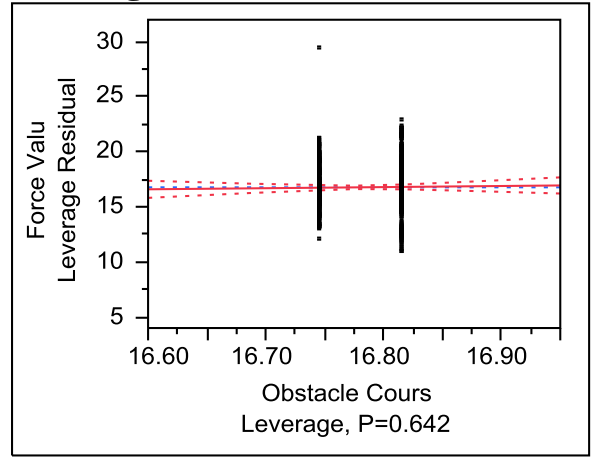

Effect Test

Sum of F Ratio DF Prob $>$ F

Squares

1.0140854

$0.2155 \quad 1 \quad 0.6426$ 
Denominator MS Synthesis:

Residual

$\begin{array}{lccr}\begin{array}{l}\text { Least Squares Means Table } \\ \text { Level }\end{array} & \begin{array}{r}\text { Least Sq } \\ \text { Mean }\end{array} & \text { Std Error } & \text { Mean } \\ & 16.816061 & 0.10900497 & 16.8161 \\ \text { ASTM } & 16.744495 & 0.10900497 & 16.7445\end{array}$

Ride Height

Leverage Plot

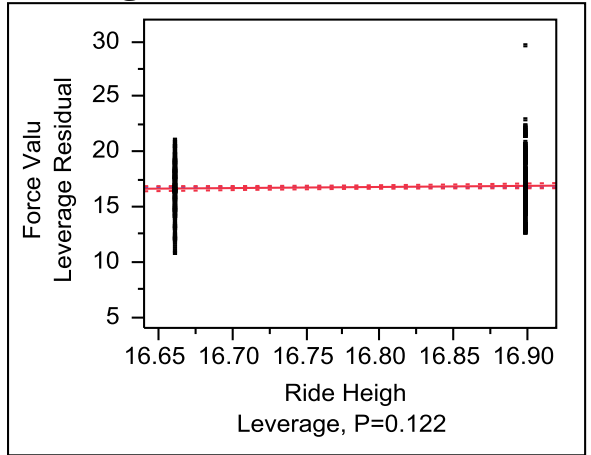

\section{Effect Test}

Sum of F Ratio DF Prob $>$ F

Squares

$\begin{array}{llll}11.237419 & 2.3882 & 1 & 0.1227\end{array}$

Denominator MS Synthesis:

Residual

Least Squares Means Table

Level Least Sq Std Error Mean

$\begin{array}{llll}\text { Low } & 16.899394 & 0.10900497 & 16.8994\end{array}$

$\begin{array}{llll}\text { High } & 16.661162 & 0.10900497 & 16.6612\end{array}$

Handling

Leverage Plot

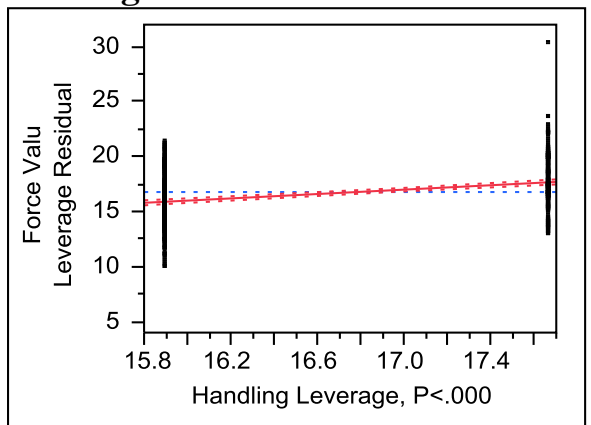




$\begin{array}{rrrr}\text { Effect Test } & & & \\ \begin{array}{c}\text { Sum of } \\ \text { Squares }\end{array} & \text { F Ratio } & \text { DF } & \text { Prob }>\text { F } \\ 617.80335 & 131.2993 & 1 & <.0001^{*}\end{array}$

Denominator MS Synthesis:

Residual

Least Squares Means Table

$\begin{array}{lrrr}\text { Level } & \begin{array}{r}\text { Least Sq } \\ \text { Mean }\end{array} & \text { Std Error } & \text { Mean } \\ \text { After } & 15.897071 & 0.10900497 & 15.8971 \\ \text { Before } & 17.663485 & 0.10900497 & 17.6635\end{array}$

Load Cell Position

Leverage Plot

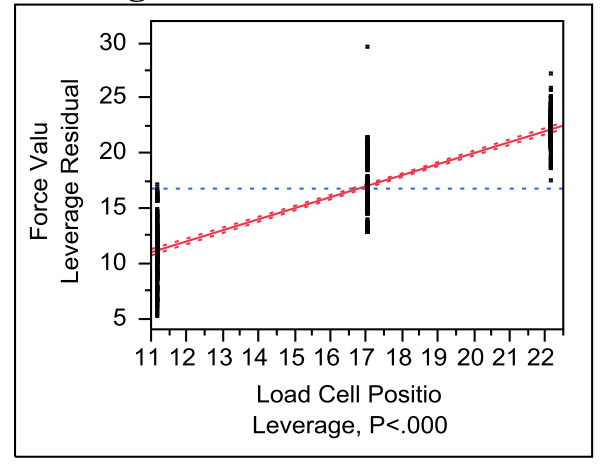

Effect Test

Sum of F Ratio DF Prob $>$ F

Squares

$15885.578 \quad 1688.050 \quad 2 \quad<.0001^{*}$

Denominator MS Synthesis:

Residual

Least Squares Means Table

Level

Least Sq Mean

$\begin{array}{llll}\text { Bottom } & 11.182045 & 0.13350327 & 11.1820\end{array}$

$\begin{array}{llll}\text { Middle } & 22.144773 & 0.13350327 & 22.1448\end{array}$

$\begin{array}{llll}\text { Top } & 17.014015 & 0.13350327 & 17.0140\end{array}$ 


\section{Time}

Leverage Plot

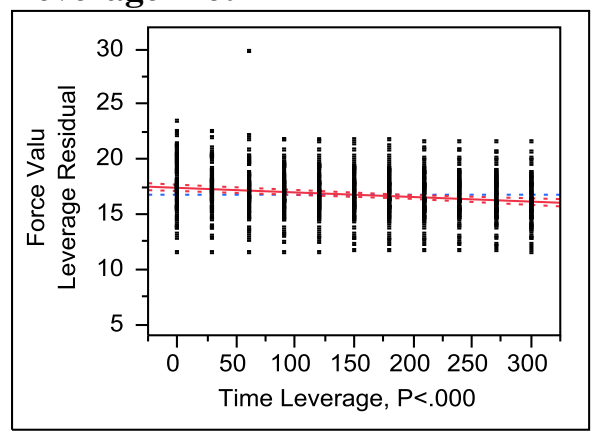

\section{Effect Test}

$\begin{array}{rccc}\begin{array}{r}\text { Sum of } \\ \text { Squares }\end{array} & \text { F Ratio } & \text { DF } & \text { Prob }>\text { F } \\ 124.07521 & 26.3692 & 1 & <.0001^{*}\end{array}$

Denominator MS Synthesis:

Residual

Driver\&Random

Effect Test

$\begin{array}{rrrr}\begin{array}{r}\text { Sum of } \\ \text { Squares }\end{array} & \text { F Ratio } & \text { DF } & \text { Prob }>\text { F } \\ 248.71171 & 26.4289 & 2 & <.0001^{*}\end{array}$

Denominator MS Synthesis:

Residual

Least Squares Means Table

$\begin{array}{lrrr}\text { Level } & \begin{array}{r}\text { Least Sq } \\ \text { Mean }\end{array} & \text { Std Error } & \text { Mean } \\ \text { Justin } & 17.091439 & 0.13350327 & 17.0914 \\ \text { Kainoa } & 17.255909 & 0.13350327 & 17.2559 \\ \text { Tyler } & 15.993485 & 0.13350327 & 15.9935\end{array}$


Film Containment Force Cross Stack

Response Force Value

Whole Model

Actual by Predicted Plot

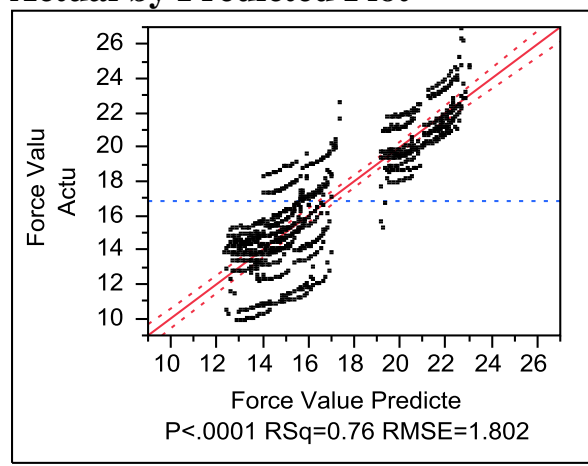

\section{Summary of Fit}

RSquare

0.755356

RSquare Adj

0.752746

Root Mean Square Error

1.802418

Mean of Response

16.84602

Observations (or Sum Wgts)

\section{Analysis of Variance}

Source DF

$\begin{array}{lrr}\text { Model } & 8 & 7522.9724\end{array}$

Error $\quad 750 \quad 2436.5340$

C. Total

$758 \quad 9959.5064$

$\begin{array}{rr}\text { Mean Square } & \text { F Ratio } \\ & \\ 940.372 & 289.4598 \\ 3.249 & \text { Prob }>\text { F } \\ & <.0001 *\end{array}$

Estimate Std Error t Ratio Prob $>|t|$
Parameter Estimates

Term 


$\begin{array}{lrrrr}\text { Term } & \text { Estimate } & \text { Std Error } & \text { t Ratio } & \text { Prob }>|\mathbf{t}| \\ \text { Intercept } & 17.594599 & 0.122599 & 143.51 & <.0001^{*} \\ \text { Obstacle Course[ASTM] } & -0.110162 & 0.065801 & -1.67 & 0.0945 \\ \text { Ride Height[Low] } & -0.001349 & 0.065801 & -0.02 & 0.9837 \\ \text { Handling[After] } & -0.954127 & 0.065801 & -14.50 & <.0001^{*} \\ \text { Load Cell Position[Bottom] } & -1.501989 & 0.092523 & -16.23 & <.0001^{*} \\ \text { Load Cell Position[Middle] } & 4.1361133 & 0.092523 & 44.70 & <.0001^{*} \\ \text { Time } & -0.004713 & 0.00069 & -6.83 & <.0001^{*} \\ \text { Driver[Justin] } & 0.2120349 & 0.091824 & 2.31 & 0.0212^{*} \\ \text { Driver[Kainoa] } & -0.107896 & 0.095474 & -1.13 & 0.2588\end{array}$

Expected Mean Squares

The Mean Square per row by the Variance Component per column

$\begin{array}{lrrrrr}\text { EMS } & \text { Intercept } & \begin{array}{r}\text { Obstacle } \\ \text { Course }\end{array} & \text { Ride Height } & \text { Handling } & \begin{array}{r}\text { Load Cell } \\ \text { Position }\end{array} \\ \text { Intercept } & 0 & 0 & 0 & 0 & 0 \\ \text { Obstacle } & 0 & 375.158 & 0 & 0 & 0 \\ \text { Course } & & & & & 0 \\ \text { Ride Height } & 0 & 0 & 375.158 & 0 & 0 \\ \text { Handling } & 0 & 0 & 0 & 375.158 & 253 \\ \text { Load Cell } & 0 & 0 & 0 & 0 & 0 \\ \text { Position } & & & & 0 & 0 \\ \text { Time } & 0 & 0 & 0 & 0 & 0 \\ \begin{array}{l}\text { Driver\&Rando } \\ \text { m }\end{array} & 0 & 0 & 0 & & \end{array}$

plus 1.0 times Residual Error Variance

$\begin{array}{lrr}\begin{array}{l}\text { Variance Component Estimates } \\ \text { Component }\end{array} & \begin{array}{r}\text { Var Comp } \\ \text { Est }\end{array} & \begin{array}{r}\text { Percent of } \\ \text { Total }\end{array} \\ \text { Driver\&Random } & 0.021625 & 0.661 \\ \text { Residual } & 3.248712 & 99.339 \\ \text { Total } & 3.270337 & 100.000\end{array}$

These estimates based on equating Mean Squares to Expected Value.

Test Denominator Synthesis

Source

Obstacle Course

Ride Height

Handling

Load Cell Position

Time

Driver\&Random
MS Den

3.24871

3.24871

3.24871

3.24871

3.24871

3.24871

\section{DF Den Denom MS} Synthesis

750 Residual

750 Residual

750 Residual

750 Residual

750 Residual

750 Residual

Tests wrt Random Effects

Source

Obstacle Course
SS MS Num

9.10559

9.10559
DF Num

1

F Ratio

2.8028
Prob > F

0.0945 
Source

Ride Height

Handling

Load Cell Position

Time

Driver\&Random
SS

0.00137

683.056

6654.41

151.727

17.3446
MS Num
0.00137
683.056
3327.2
151.727
8.67228

DF Num

Prob > F
0.9837
$<.0001^{*}$
$<.0001^{*}$
$<.0001^{*}$
0.0699

$0.0004 \quad 0.9837$

$210.2543<.0001^{*}$

1024.161

46.7037

2.6695

\section{Residual by Predicted Plot}

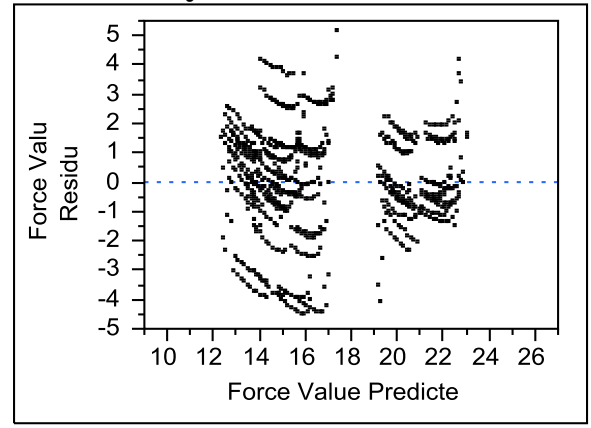

Obstacle Course

\section{Leverage Plot}

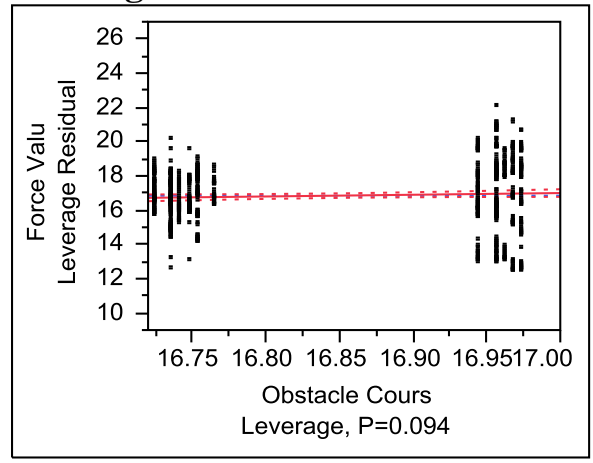

\section{Effect Test}

$\begin{array}{rrrr}\begin{array}{r}\text { Sum of } \\ \text { Squares }\end{array} & \text { F Ratio } & \text { DF } & \text { Prob }>\text { F } \\ 9.1055881 & 2.8028 & 1 & 0.0945\end{array}$

Denominator MS Synthesis:

Residual

Least Squares Means Table

Level
Mean

$\begin{array}{llll}\text { ASTM } & 16.777500 & 0.09057493 & 16.7775\end{array}$

ISTA

16.997824
Std Error Mean

$0.09547436 \quad 16.9208$ 
Ride Height

Leverage Plot

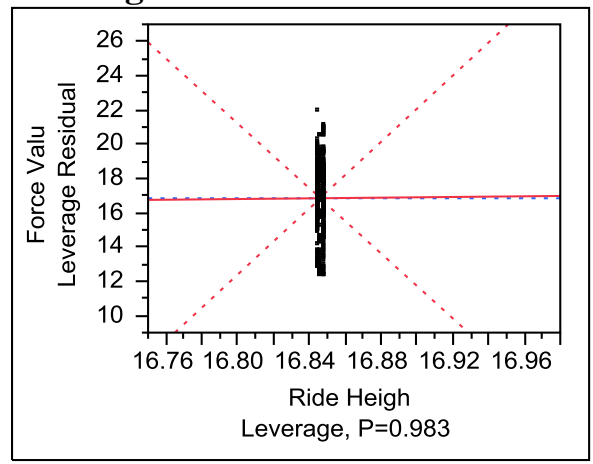

Effect Test

$\begin{array}{rrcr}\begin{array}{r}\text { Sum of } \\ \text { Squares }\end{array} & \text { F Ratio } & \text { DF } & \text { Prob }>\text { F } \\ 0.00136523 & 0.0004 & 1 & 0.9837\end{array}$

Denominator MS Synthesis:

Residual

\begin{tabular}{|c|c|c|c|}
\hline \multicolumn{4}{|c|}{ Least Squares Means Table } \\
\hline Level & $\begin{array}{r}\text { Least Sq } \\
\text { Mean }\end{array}$ & Std Error & Mean \\
\hline Low & 16.886313 & 0.09057493 & 16.8863 \\
\hline High & 16.889011 & 0.09547436 & 16.8021 \\
\hline
\end{tabular}

Handling

Leverage Plot

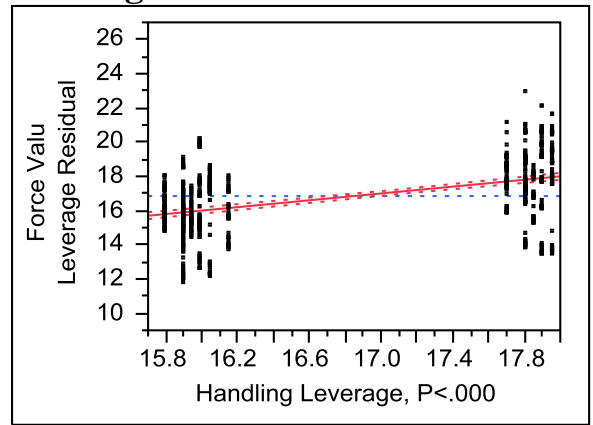

Effect Test

Sum of F Ratio DF Prob $>$ F

Squares

$683.05578 \quad 210.2543 \quad 1 \quad<.0001 *$

Denominator MS Synthesis: 
Residual

Least Squares Means Table

$\begin{array}{llll}\text { Level } & \begin{array}{l}\text { Least Sq } \\ \text { Mean }\end{array} & \text { Std Error } & \text { Mean } \\ \text { After } & 15.933535 & 0.09057493 & 15.9335 \\ \text { Before } & 17.841789 & 0.09547436 & 17.8415\end{array}$

Load Cell Position

Leverage Plot

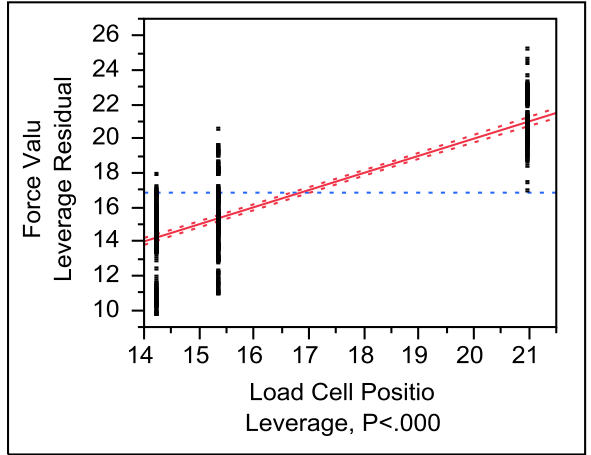

Effect Test

Sum of F Ratio DF Prob $>$ F

Squares

$6654.4096 \quad 1024.161 \quad 2 \quad<.0001 *$

Denominator MS Synthesis:

Residual

Least Squares Means Table

$\begin{array}{llll}\text { Level } & \begin{array}{l}\text { Least Sq } \\ \text { Mean }\end{array} & \text { Std Error } & \text { Mean } \\ \text { Bottom } & 15.385673 & 0.11353545 & 15.3440 \\ \text { Middle } & 21.023775 & 0.11353545 & 20.9821 \\ \text { Top } & 14.253538 & 0.11353545 & 14.2119\end{array}$

Time

Leverage Plot

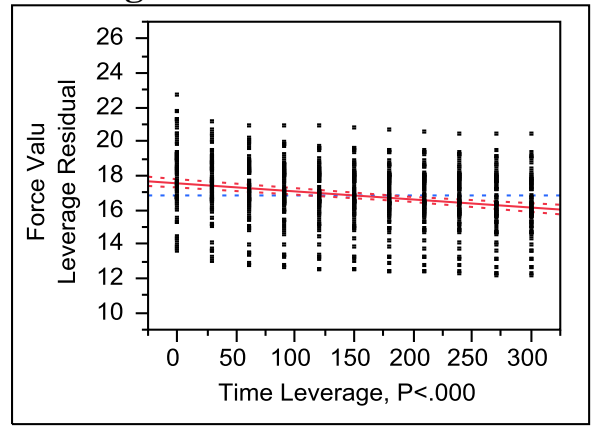




$\begin{array}{rccr}\text { Effect Test } & & & \\ \begin{array}{c}\text { Sum of } \\ \text { Squares }\end{array} & \text { F Ratio } & \text { DF } & \text { Prob }>\text { F } \\ 151.72701 & 46.7037 & 1 & <.0001^{*}\end{array}$

Denominator MS Synthesis:

Residual

Driver\&Random

Effect Test

Sum of F Ratio DF Prob $>$ F

Squares

$\begin{array}{llll}17.344550 & 2.6695 & 2 & 0.0699\end{array}$

Denominator MS Synthesis:

Residual

Least Squares Means Table

Level Least Sq

Std Error Mean

Justin $\quad 17.099697$

$0.11093118 \quad 17.0997$

Kainoa

16.779766

0.11981937

16.6275

Tyler

16.783523

0.11093118

16.7835 


\section{Appendix C: RSC Compression Data}

Down Under RSC Compression Data

\begin{tabular}{|c|c|c|}
\hline Orientation & Peak Force (lbs.) & Deflection at Peak (in.) \\
\hline 1 & 701.4 & 0.44 \\
\hline 1 & 617.6 & 0.52 \\
\hline 1 & 823 & 0.46 \\
\hline 1 & 604.8 & 0.36 \\
\hline 1 & 625.1 & 0.33 \\
\hline 2 & 361.6 & 0.34 \\
\hline 2 & 352.9 & 0.33 \\
\hline 2 & 373.7 & 0.34 \\
\hline 2 & 290.4 & 0.29 \\
\hline 2 & 323.8 & 0.28 \\
\hline 3 & 250.4 & 0.21 \\
\hline 3 & 144.5 & 1.39 \\
\hline 3 & 371.6 & 0.41 \\
\hline 3 & 321.5 & 0.43 \\
\hline 3 & 258.3 & 0.67 \\
\hline
\end{tabular}




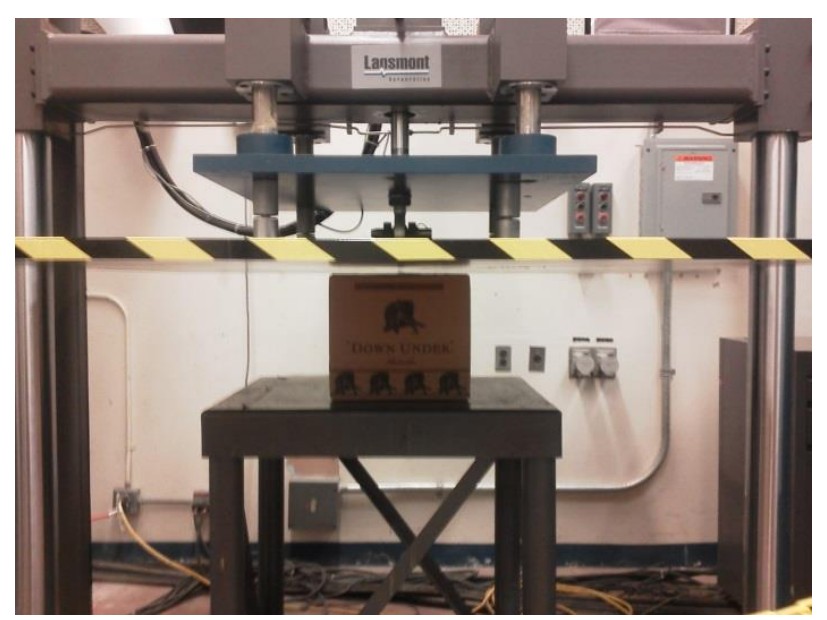

Compression Orientation 1

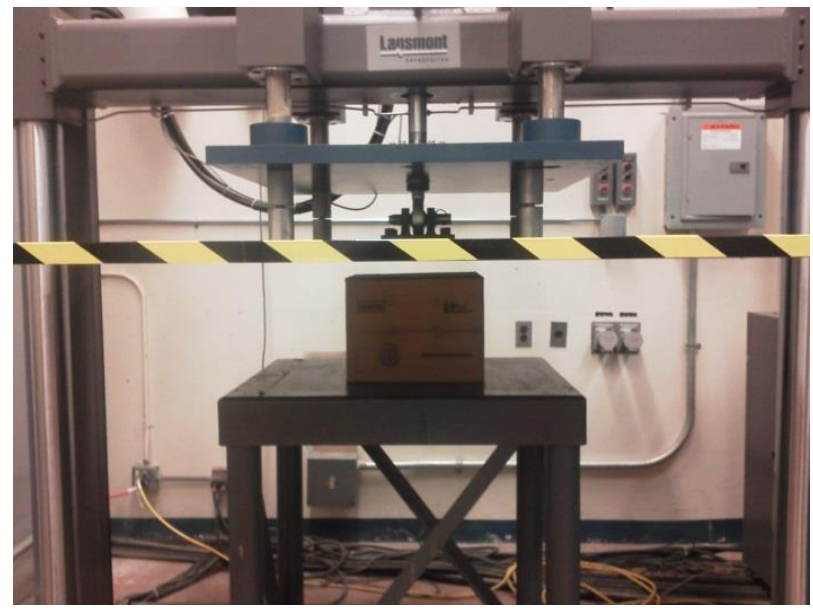

Compression Orientation 2

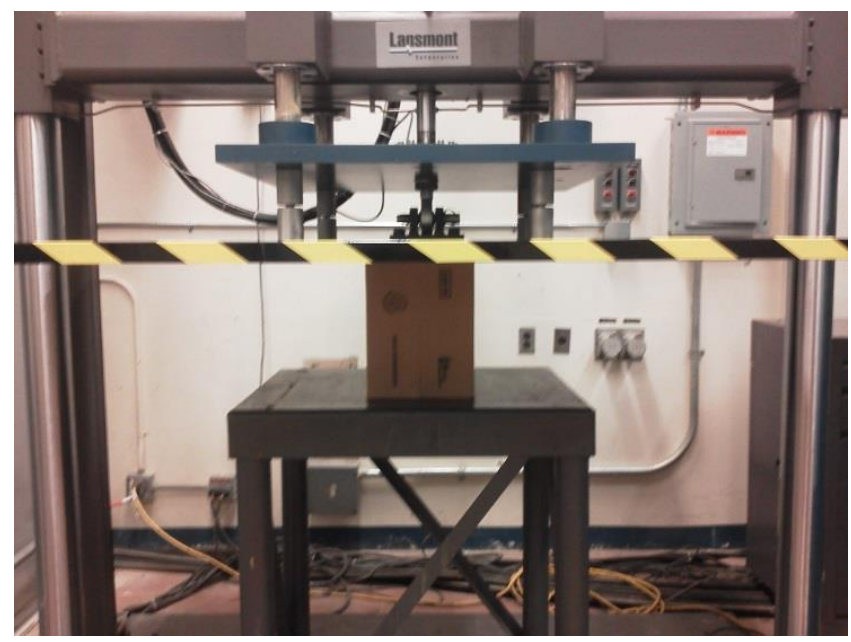

Compression Orientation 3 


\section{Appendix D: Corrugated Edge Crush Data}

Down Under RSC Corrugated Edge Crush Test

\begin{tabular}{|c|c|}
\hline Sample \# & Peak Force (lbs.) \\
\hline 1 & 33.46 \\
\hline 2 & 31.11 \\
\hline 3 & 46.97 \\
\hline 4 & 40.03 \\
\hline 5 & 35.54 \\
\hline 6 & 32.07 \\
\hline 7 & 33.74 \\
\hline 8 & 31.92 \\
\hline 9 & 38.21 \\
\hline 10 & 44.14 \\
\hline 11 & 41.58 \\
\hline 12 & 38.87 \\
\hline 13 & 41.43 \\
\hline 14 & 41.41 \\
\hline 15 & 47.99 \\
\hline 16 & 42.64 \\
\hline 17 & 32.85 \\
\hline 18 & 31.18 \\
\hline 19 & 44.55 \\
\hline 20 & 33.43 \\
\hline
\end{tabular}


Coefficient of Friction Test

MD: Machine Direction

CD: Cross Direction

Corrugated on Corrugated Slide Angle

\begin{tabular}{|c|c|c|}
\hline MDxMD & CDxMD & CDxCD \\
\hline $15^{\circ}$ & $15^{\circ}$ & $16^{\circ}$ \\
\hline $15^{\circ}$ & $15^{\circ}$ & $16^{\circ}$ \\
\hline $14.5^{\circ}$ & $15.5^{\circ}$ & $14^{\circ}$ \\
\hline
\end{tabular}

Film on Corrugated

Slide Angle

\begin{tabular}{|c|c|c|}
\hline MDxMD & CDxMD & CDxCD \\
\hline $23^{\circ}$ & $24.5^{\circ}$ & $22^{\circ}$ \\
\hline $24^{\circ}$ & $23^{\circ}$ & $22.5^{\circ}$ \\
\hline $22.5^{\circ}$ & $23^{\circ}$ & $21.5^{\circ}$ \\
\hline
\end{tabular}

